\title{
Toekomstverkenning arbeidsmarkt zorgsector
}

Citation for published version (APA):

de Grip, A., Willems, E. J. T. A., Hoevenberg, J., van de Loo, P. J. E., \& Matheeuwsen, A. G. M. (1994). Toekomstverkenning arbeidsmarkt zorgsector. Researchcentrum voor Onderwijs en Arbeidsmarkt, Faculteit der Economische Wetenschappen. ROA Reports No. 6 https://doi.org/10.26481/umarep.1994006

Document status and date:

Published: 01/01/1994

DOI:

10.26481/umarep.1994006

Document Version:

Publisher's PDF, also known as Version of record

\section{Please check the document version of this publication:}

- A submitted manuscript is the version of the article upon submission and before peer-review. There can be important differences between the submitted version and the official published version of record.

People interested in the research are advised to contact the author for the final version of the publication, or visit the DOI to the publisher's website.

- The final author version and the galley proof are versions of the publication after peer review.

- The final published version features the final layout of the paper including the volume, issue and page numbers.

Link to publication

\footnotetext{
General rights rights.

- You may freely distribute the URL identifying the publication in the public portal. please follow below link for the End User Agreement:

www.umlib.nl/taverne-license

Take down policy

If you believe that this document breaches copyright please contact us at:

repository@maastrichtuniversity.nl

providing details and we will investigate your claim.
}

Copyright and moral rights for the publications made accessible in the public portal are retained by the authors and/or other copyright owners and it is a condition of accessing publications that users recognise and abide by the legal requirements associated with these

- Users may download and print one copy of any publication from the public portal for the purpose of private study or research.

- You may not further distribute the material or use it for any profit-making activity or commercial gain

If the publication is distributed under the terms of Article $25 \mathrm{fa}$ of the Dutch Copyright Act, indicated by the "Taverne" license above, 
TOEKOMSTVERKENNING ARBEIDSMARKT ZORGSECTOR

ROA-R-1994/6
A. de Grip
E.J.T.A. Willems
J. Hoevenberg
P.J.E. van de Loo
A.G.M. Matheeuwsen

RESEARCHCENTRUM VOOR ONDERWIJS EN ARBEIDSMARKT

Faculteit der Economische Wetenschappen

Rijksuniversiteit Limburg

Maastricht, mei 1994 
CIP-GEGEVENS KONINKLIJKE BIBLIOTHEEK, DEN HAAG

Toekomstverkenning

Toekomstverkenning arbeidsmarkt zorgsector / A. de Grip ... [et al.]. - Maastricht : Researchcentrum voor Onderwijs en Arbeidsmarkt, Faculteit der Economische Wetenschappen, Rijksuniversiteit Limburg. - ([Rapport] / Researchcentrum voor Onderwijs en Arbeidsmarkt, ISSN 0922-8098; ROA-R-1994/6)

ISBN 90-5321-131-4 geb.

Trefw.: arbeidsmarkt ; gezondheidszorg. 


\section{INHOUDSOPGAVE}

Bladzijde

VOORWOORD

2. RECENTE ARBEIDSMARKTONTWIKKELINGEN IN DE ZORGSECTOR 6

2.1. Inleiding 6

2.2. Zorgbehoefte en zorgvolume 6

2.3. Monitoring arbeidsmarktknelpunten en imago gezondheidszorg 12

2.4. Werkgelegenheid 28

2.5. Vervangingsvraag 32

2.6. Instroom van schoolverlaters 33

3. DE ARBEIDSMARKT IN DE ZORGSECTOR OP MIDDELLANGE TERMIJN 37

$\begin{array}{ll}3.1 . & \text { Inleiding } \\ 3.27\end{array}$

3.2. Uitbreidingsvraag 37

3.3. Vervangingsvraag 39

3.4. Baanopeningen 41

3.5. Instroom van schoolverlaters 41

3.6. Toekomstige arbeidsmarktsituatie 42

4. TOEKOMSTSCENARIO'S VOOR DE NEDERLANDSE ECONOMIE

4.1. Inleiding 44

4.2. Global Shift 44

4.3. Balanced Growth 48

4.4. European Renaissance 50

4.5. De drie scenario's samengevat 53

5. GLOBAL SHIFT

5.1. Inleiding 56

5.2. Uitbreidingsvraag $\quad 58$

5.3. Vervangingsvraag 60

5.4. Baanopeningen 61

5.5. Instroom van schoolverlaters 64

5.6. Toekomstige arbeidsmarktsituatie 64 
6. BALANCED GROWTH

6.1. Inleiding 67

6.2. Uitbreidingsvraag 70

6.3. Vervangingsvraag 73

$\begin{array}{ll}\text { 6.4. Baanopeningen } & 75\end{array}$

$\begin{array}{ll}\text { 6.5. Instroom van schoolverlaters } & 77\end{array}$

6.6. Toekomstige arbeidsmarktsituatie 78

7. EUROPEAN RENAISSANCE

$\begin{array}{ll}\text { 7.1. Inleiding } & 80\end{array}$

7.2. Uitbreidingsvraag 82

7.3. Vervangingsvraag 85

$\begin{array}{ll}\text { 7.4. Baanopeningen } & 87\end{array}$

7.5. Instroom van schoolverlaters $\quad 89$

$\begin{array}{ll}\text { 7.6. Toekomstige arbeidsmarktsituatie } & 90\end{array}$

8. DE DRIE SCENARIO'S SAMENGEVAT 92

8.1. Inleiding 92

8.2. Uitbreidingsvraag 93

8.3. Vervangingsvraag $\quad 95$

8.4. Baanopeningen 96

8.5. Instroom van schoolverlaters 98

8.6. Toekomstige arbeidsmarktsituatie 99

$\begin{array}{lr}\text { LITERATUUR } & 102\end{array}$ 


\section{VOORWOORD}

In dit rapport wordt uitgebreid verslag gedaan van de arbeidsmarktontwikkelingen die zich tot 2005 in de zorgsector kunnen voordoen, waarbij wordt aangesloten bij de drie door het Centraal Planbureau (CPB) onderscheiden lange-termijn-scenario's Global Shift, Balanced Growth en European Renaissance. Deze scenario-studie moet worden gezien als een handvat voor de toekomstige lange-termijn-beleidsontwikkeling ten aanzien van de arbeidsmarkt in de zorgsector. Het zijn derhalve niet drie varianten van een prognose, waarvan er één het meest waarschijnlijk is, maar het zijn, zoals ook is aangegeven door het CPB, denkmodellen voor de lange-termijnontwikkeling. Het interessante voor de zorgsector is daarbij ook dat de toekomstige arbeidsmarktproblematiek gerelateerd wordt aan het algehele zorgsectorbeleid. Hopelijk heeft dit rapport op dit punt een 'aanjaagfunctie' voor de beleidsdiscussie en draagt het bij aan een beter besef van de mogelijke wisselwerkingen tussen het zorgbeleid en het arbeidsmarktbeleid in de zorgsector en de implicaties daarvan voor de arbeidsmarktsituatie in de zorgberoepen. Vooruitlopend op deze 'beleidsrijke' lange-termijn-scenario's wordt in hoofdstuk 3 van dit rapport een raming van de arbeidsmarktontwikkelingen op de middellange termijn gepresenteerd, toegespitst op vier in dit onderzoek onderscheiden beroepsgroepen. Deze middellange-termijn-verkenning heeft slechts als doel een momentopname te geven van de arbeidsmarktsituatie in de zorgberoepen voor een tussenliggend jaar, maar staat verder los van de drie lange-termijn-scenario's. In dit rapport wordt vrijwel niet ingegaan op de gehanteerde werkwijze. Daarvoor wordt verwezen naar het werkdocument Opzet en methodiek scenario's arbeidsmarkt zorgsector (De Grip, Willems, Hoevenberg, Van de Loo en Matheeuwsen, 1994).

Het onderzoek is uitgevoerd in opdracht van het Ministerie van Welzijn, Volksgezondheid en Cultuur (WVC). De projectleiding van het onderzoek was in handen van dr. A. de Grip. Verder is aan het onderzoek meegewerkt door drs. E.J.T.A. Willems, drs. J. Hoevenberg, drs. P.J.E. van de Loo en drs. A.G.M. Matheeuwsen. M.E.C. Reiners verleende assistentie bij het verzamelen en verwerken van de gegevens. Een woord van dank wordt gericht aan de leden van de voor dit onderzoek samengestelde begeleidingscommissie:

drs. N.C.M. van Niekerk (voorzitter) Centrale fondsen

drs. N.E.J. Kuyper (secretaris)

Ministerie van WVC/CDFEZ

drs. M. Bottema (adjunct-secretaris)

Ministerie van WVC/CDFEZ

drs. R.M.A. Asrafali

Vereniging Nederlandse Bejaardenoorden (VNB)

drs. H.K. Griffioen

Ministerie van WVC/DGW

MSc. M.H. Hanrahan (plv. lid)

Ministerie van WVC/VGZ

drs. P.J. de Jonge

Landelijke Vereniging voor Thuiszorg (LVT)

drs. D. Lont

Ministerie van WVC/VGZ

drs. H.J. Roodenburg

Centraal Planbureau (CPB)

drs. F. Vos (plv. lid)

Ministerie van WVC/DGW

drs. W. van der Windt

Nationaal Ziekenhuisinstituut (NZi)

Daarnaast is dank verschuldigd aan drs. P. Dekker en drs. W. Vossers van het CPB voor hun bereidwillige medewerking bij het beantwoorden van verschillende specifieke vragen met betrekking tot de CPB-scenario-studie. 



\section{INLEIDING}

\section{Achtergrond}

De arbeidsmarktsituatie in de zorgsector is doorgaans aan sterke fluctuaties onderhevig. Deze fluctuaties vloeien enerzijds voort uit de dynamiek van het arbeidsaanbod, die zich in de gezondheidszorg nogal eens manifesteert in de vorm van zogenaamde 'varkenscycli', als gevolg van een overreactie van het arbeidsaanbod op bestaande personeelstekorten of -overschotten. Anderzijds is er vanwege demografische factoren en de hoge baan-baan mobiliteit vaak een grote dynamiek in de vervangingsbehoefte, terwijl demografische factoren en het gevoerde overheidsbeleid grote gevolgen hebben voor de ontwikkeling van de werkgelegenheid ${ }^{1}$. Door de nauwe relatie tussen opleiding en beroep in de zorgsector kunnen dergelijke fluctuaties op korte termijn moeilijk worden opgevangen door anders opgeleiden. Zoals de laatste jaren veelvuldig is gebleken is het een grote 'zorg voor de Zorg' om te voorkomen dat arbeidsmarktknelpunten langs directe of indirecte weg (negatief imago, excessieve loonontwikkelingen e.d.) tot een aantasting van het voorzieningenniveau leiden. Deze dreiging noodzaakt tot een preventief arbeidsmarktbeleid dat zich in belangrijke mate dient te baseren op prognoses van de mogelijke toekomstige ontwikkelingen op de arbeidsmarkt (zie ook De Grip, 1988).

Tot op heden kenmerken arbeidsmarktprognoses voor de zorgsector zich door beleidsarme benaderingen, waarbij met name demografische ontwikkelingen bepalend zijn voor de verwachte ontwikkelingen in de vraag. De arbeidsmarktprognoses voor verpleegkundigen en verzorgenden die in het begin van de jaren '90 zijn gepubliceerd (Gerritse en Van der Windt, 1991 en Vissers, Evers, Van Tits, Vermeulen en Euwals, 1991), zijn opgesteld vanuit de achterliggende gedachte dat het gegroeide tekort aan verpleegkundigen in de nabije toekomst nog veel nijpender zou kunnen worden. Op basis van de te verwachten demografische ontwikkelingen is er enerzijds een impuls tot een groeiende zorgbehoefte als gevolg van de vergrijzing van de bevolking en anderzijds een dalend aanbod van jongeren door de ontgroening van de beroepsbevolking. Bovendien zou de arbeidsmarktproblematiek voor de zorgsector nog vergroot kunnen worden door het mogelijk ongunstige imago van de werkbelasting en de beloning van het werk in verpleegkundige en verzorgende functies.

De relevantie van de in dit rapport beschreven scenario-studie kan in een ruimer kader worden geplaatst. Weliswaar gaat het in de eerste plaats om de mogelijke consequenties van de demografische ontwikkelingen en de arbeidsmarktpositie van de zorgsector voor de toekomstige arbeidsmarktsituatie voor verpleegkundigen en verzorgenden. Ditmaal wordt deze problematiek echter uitdrukkelijk geplaatst in het kader van de vanuit beleidsoogpunt steeds urgenter wordende fundamentele vragen over de richting waarin de zorgsector zich zou kunnen, dan wel dienen te ontwikkelen.

1. Borghans (1993) toont aan dat bij de eveneens vaak aan sterke schommelingen onderhevige arbeidsmarkt voor onderwijzers de vervangingsvraag en de invloed van het overheidsbeleid de belangrijkste oorzaken van arbeidsmarktonevenwichtigheden zijn. 
Door de prognoses voor de zorgsector te baseren op de drie door het Centraal Planbureau (CPB) geformuleerde lange-termijn-scenario's voor de Nederlandse economie (CPB, 1992a), kan voor het eerst sprake zijn van 'beleidsrijke' prognoses van de arbeidsmarktsituatie in de zorgsector. Een belangrijk voordeel van een dergelijke aanpak is dat de met name voor de lange termijn irreële ongewijzigd-beleid benadering wordt losgelaten. Er moet immers worden beseft dat de CPB-scenario's niet zoals voorheen gemodelleerd zijn als een drietal varianten van de mogelijke toekomstige economische groei, op basis waarvan gebruikelijk de midden-variant als uitgangspunt dient voor allerhande andere prognoses van ontwikkelingen op deelterreinen. In plaats daarvan heeft het CPB een drietal scenario's geformuleerd op basis van verschillende visies op de fundamentele krachten die het proces van economische ontwikkeling sturen en de daaruit voortvloeiende rol van het overheidsbeleid. Deze scenario's houden dus in feite al een fundamentele keuze in van het te voeren beleid op allerlei maatschappelijke deelgebieden. Door het CPB worden daarbij de volgende drie scenario's onderscheiden:

- Global Shift;

- Balanced Growth;

- European Renaissance.

Voor het opstellen van toekomstscenario's voor de zorgsector en de arbeidsmarkt van verpleegkundigen en verzorgenden, is met name een tweetal aspecten van de CPB-scenario's van belang: de visie op het functioneren van de arbeidsmarkt en de visie op het overheidsbeleid ten aanzien van de zorgsector. Het Global Shift scenario zou wat dit betreft grofweg getypeerd kunnen worden als het ongewijzigd-beleid scenario ('doormodderen'), waarbij met betrekking tot zowel het arbeidsmarktbeleid als het zorgbeleid, wordt verwacht dat vanaf het jaar 2005 in hoog tempo zeer krachtige maatregelen dwingend genomen moeten worden om de rigiditeiten op de arbeidsmarkt en de kostenstijgingen in de zorgsector te doorbreken.

Het Balanced Growth scenario kenmerkt zich daarentegen op alle terreinen door het nastreven van een betere marktwerking. Voor de arbeidsmarkt betekent dit het versterken van financiële prikkels en het opheffen van bestaande institutionele belemmeringen voor het adequaat functioneren van het marktmechanisme. Ten aanzien van de zorgsector behelst dit scenario een sterke vergroting van de financiële prikkels voor alle betrokkenen aan zowel de aanbod- als de vraagzijde van de arbeidsmarkt.

In het European Renaissance scenario zijn de (nagestreefde) prijssignalen minder sterk en spelen met name hoeveelheidssignalen een rol. Voor de arbeidsmarkt komt dit bijvoorbeeld tot uiting in de policy-mix van een 'actief en activerend arbeidsmarktbeleid'. Ten aanzien van de zorgsector staan in dit scenario niet zozeer de financiële prikkels bij aanbieders en vragers centraal, maar veeleer een door het door de overheid gestimuleerde beleid van samenwerkende verzekeraars.

\section{Probleemstelling}

De centrale onderzoeksvraag van deze studie kan als volgt worden geformuleerd: 
Welke ontwikkelingen zullen zich op de arbeidsmarkt in de zorgsector, verbijzonderd naar deelsector en beroepsgroep, binnen de drie door het Centraal Planbureau geschetste langetermijn-scenario's voordoen?

Vooruitlopend op deze 'beleidsrijke' lange-termijn-scenario's zal nader worden ingegaan op de verwachte arbeidsmarktontwikkelingen in de zorgsector op de middellange termijn. Daarbij wordt aangesloten bij de middellange-termijn-ramingen die door het CPB (1993) in het Centraal Economisch Plan 1993 zijn gepubliceerd. Gezien de recente economische ontwikkelingen wordt uitgegaan van het door het CPB onderscheiden behoedzame scenario. Deze middellange-termijnprognoses hebben slechts als doel om een momentopname te geven van de arbeidsmarktsituatie in de zorgberoepen voor een tussenliggend jaar. Daarbij is, uitgaande van de CPB-prognose voor de kwartaire diensten geen verdere invulling gegeven van het de komende jaren ten aanzien van de zorgsector gevoerde overheidsbeleid.

Met betrekking tot de arbeidsmarktontwikkelingen in de zorgsector zijn de CPB-scenario's en ook de middellange-termijn-raming van het CPB niet of nauwelijks uitgewerkt. Een uitzondering is wat dit betreft de verwachte totale werkgelegenheid in de kwartaire dienstverlening, die echter meer omvat dan de zorgsector alleen. De arbeidsmarktsituatie, bij een confrontatie van vraag en aanbod, wordt door het CPB slechts uitgewerkt naar opleidingsniveau en opleidingsrichting. Hierbij is de richting 'verzorgend' in feite als een zeer heterogene 'restgroep' gedefinieerd en derhalve vanuit arbeidsmarktoogpunt weinig relevant.

In deze studie zullen binnen de globale randvoorwaarden van de CPB-scenario's de verschillende componenten van de arbeidsmarktsituatie expliciet in beeld worden gebracht. Daarbij wordt aangesloten bij de in het kader van het door het ROA ontwikkelde informatiesysteem onderwijsarbeidsmarkt gemaakte onderscheid tussen de uitbreidingsvraag (werkgelegenheidsontwikkeling), de vervangingsvraag en het aanbod van nieuwkomers op de arbeidsmarkt (zie ROA 1993). Deze stroombenadering maakt het mogelijk meer inzicht te krijgen in de componenten van de dynamiek op de arbeidsmarkt. Met name het afzonderlijk modelleren van de vervangingsbehoefte op een relatief laag aggregatieniveau is voor de zorgsector van groot belang. De in dit rapport te presenteren lange-termijn-scenario's zullen betrekking hebben op de periode 19932005 en het daaruit resulterende beeld van de arbeidsmarktsituatie in $2005^{2}$. De middellangetermijn-prognose brengt de verwachte arbeidsmarktontwikkelingen tot 1998 in beeld.

\section{Plaatsbepaling van het onderzoek}

De belangrijkste doelstelling van dit onderzoek is het stimuleren van beleidsdiscussies ten aanzien van de mogelijke wisselwerking tussen het zorgbeleid en het te voeren arbeidsmarktbeleid in de zorgsector. Daarmee wordt hopelijk een beter zicht verkregen op de implicaties van zowel het zorgbeleid als het arbeidsmarktbeleid voor de toekomstige arbeidsmarktsituatie in de

2. De CPB-scenariostudie heeft in feite betrekking op de periode 1990-2015. Daarbij worden telkens ook voor het tussenliggende jaar 2005 de resultaten gepresenteerd. Door in hoog tempo krachtige maatregelen te nemen, verandert het Global Shift scenario vanaf dat jaar sterk van karakter. 
zorgberoepen. Door aan te haken bij de drie door het CPB ontwikkelde lange-termijn-scenario's worden in kwalitatieve en kwantitatieve zin de 'hoeken van het speelveld' van de arbeidsmarktontwikkelingen van de zorgberoepen aangegeven.

\section{Afbakening zorgsector}

De hierboven geformuleerde probleemstelling moet worden aangescherpt wat betreft de definitie van de 'zorgsector'. In de eerste plaats wordt het onderzoek beperkt tot een zevental deelsectoren binnen de zorgverlening. Ten tweede wordt een afbakening gemaakt ten aanzien van de te onderscheiden beroepsgroepen. Alleen de verplegende en verzorgende beroepen zijn in het onderzoek betrokken, waarbij degenen die nog in opleiding zijn buiten beschouwing blijven. Ook de arbeidsmarktontwikkelingen voor artsen en specialisten en bijvoorbeeld het administratief-ondersteunend personeel blijven in dit onderzoek buiten beschouwing. Schema 1.1 geeft een overzicht van de in dit onderzoek gehanteerde afbakening van de zorgsector, verbijzonderd naar deelsector en beroepsgroep. Tabel 1.1 geeft vervolgens een beeld van het aantal werkenden in de deelsectoren en beroepsgroepen in 1990.

Schema 1.1. Afbakening van deelsectoren en beroepsgroepen in de zorgsector

\begin{tabular}{|c|c|c|c|c|}
\hline Deelsector & $\begin{array}{l}\text { verpleeg- } \\
\text { kundigen }\end{array}$ & $\begin{array}{c}\text { Beroe } \\
\text { zieken- } \\
\text { verzorgenden }\end{array}$ & $\begin{array}{l}\text { groep } \\
\text { verzorgenden }\end{array}$ & helpenden \\
\hline ziekenhuizen & $x$ & $x$ & & \\
\hline psychiatrische ziekenhuizen & $x$ & $x$ & & \\
\hline verpleeghuizen & $x$ & $x$ & & \\
\hline gehandicaptenzorg & $x$ & $x$ & & \\
\hline gezinszorg & & & $x$ & $x$ \\
\hline kruiswerk & $x$ & $\mathrm{x}$ & $x$ & \\
\hline bejaardenoorden & $x$ & $x$ & $x$ & $x$ \\
\hline
\end{tabular}

Tabel 1.1. Aantal werkenden per deelsector en beroepsgroep 1990

\begin{tabular}{|c|c|c|c|c|}
\hline \multirow[b]{2}{*}{ deelsector } & \multirow[b]{2}{*}{$\begin{array}{l}\text { verpleeg- } \\
\text { kundigen }\end{array}$} & \multicolumn{2}{|c|}{ Beroepsgroep } & \multirow[b]{2}{*}{ helpenden } \\
\hline & & $\begin{array}{l}\text { zieken- } \\
\text { verzorgenden }\end{array}$ & verzorgenden & \\
\hline ziekenhuizen $^{a}$ & 52.100 & 2.700 & - & - \\
\hline psychiatrische ziekenhuizen ${ }^{a}$ & 10.300 & 1.800 & - & - \\
\hline verpleeghuizen ${ }^{a}$ & 6.500 & 27.700 & - & - \\
\hline gehandicaptenzorg $^{\mathrm{B}}$ & 15.100 & 600 & - & - \\
\hline gezinszorg & - & - & 14.900 & 60.800 \\
\hline kruiswerk & 8.500 & 2.200 & 5.300 & - \\
\hline bejaardenoorden & 5.100 & 9.700 & 16.400 & 7.500 \\
\hline \multicolumn{5}{|c|}{$\begin{array}{l}\text { Verdeling verpleegkundigen en ziekenverzorgenden op basis van cijfers } 1985 \text { en aantal gediplomeerden } \\
1990\end{array}$} \\
\hline
\end{tabular}


Opzet

De verdere opzet van deze studie is als volgt. Alvorens wordt ingegaan op de lange-termijntoekomstscenario's en de middellange-termijn-prognoses voor de arbeidsmarktontwikkelingen in de zorgsector, zal eerst in hoofdstuk 2 een beeld worden geschetst van de recente arbeidsmarktontwikkelingen in de zorgsector. In dit hoofdstuk wordt een aantal indicatoren gepresenteerd die meer zicht kunnen bieden op de eventuele kwantitatieve en kwalitatieve knelpunten die zich de afgelopen jaren op de arbeidsmarkt in de zorgsector hebben gemanifesteerd. Daarnaast wordt in dit hoofdstuk ingegaan op de achterliggende dynamiek van de gesignaleerde arbeidsmarktknelpunten in het recente verleden. Daarbij komen de werkgelegenheidsontwikkeling in de onderscheiden deelsectoren en beroepsgroepen aan bod, evenals de ontwikkelingen in het personeelsverloop en in de instroom van schoolverlaters in de zorgsector. Daarmee vormt het tweede hoofdstuk tevens een opstap naar de volgende hoofdstukken van het rapport.

Hoofdstuk 3 geeft vervolgens de verwachte ontwikkelingen in de zorgberoepen voor de middellange termijn aan. Daarbij worden de afzonderlijke arbeidsmarktstromen apart belicht en vindt een confrontatie van de totale toekomstige vraag met de totale toekomstige arbeidsmarktinstroom plaats. De verwachte werkgelegenheidsontwikkeling wordt bovendien verbijzonderd naar provincie. Gezien de huidige economische ontwikkeling wordt bij de middellangetermijn-raming uitgegaan van het door het CPB onderscheiden behoedzame scenario.

Daarna zal in hoofdstuk 4 nader worden ingegaan op de hoofdlijnen van de drie CPB-scenario's, waarbij telkens eerst de karakteristieken van het scenario zullen worden aangegeven, gevolgd door de verwachte algemene sociaal-economische ontwikkelingen in Nederland. Vervolgens wordt een toespitsing gemaakt op de rol van de overheid en de in de drie scenario's verwachte arbeidsmarktontwikkelingen. Ten slotte zal in dit hoofdstuk worden aangegeven welke ontwikkelingen het CPB in haar scenariostudie verwacht ten aanzien van de zorgsector.

Vervolgens zal in de hoofdstukken 5, 6 en 7 een overzicht worden gegeven van de verwachte ontwikkelingen op de arbeidsmarkt in de onderscheiden deelsectoren en beroepsgroepen van de zorg. Daarbij komen achtereenvolgens de scenario's Global Shift (hoofdstuk 5), Balanced Growth (hoofdstuk 6) en European Renaissance (hoofdstuk 7) aan de orde. Ook in deze hoofdstukken wordt achtereenvolgens telkens ingegaan op de uitbreidingsvraag, vervangingsvraag, het totaal aantal baanopeningen, de instroom van schoolverlaters en de toekomstige arbeidsmarktsituatie. In hoofdstuk 8 worden tenslotte de belangrijkste resultaten van de drie scenario's nog eens kort samengevat. Daarmee worden ook de verschillen in ontwikkelingen tussen de scenario's belicht. 


\section{RECENTE ARBEIDSMARKTONTWIKKELINGEN IN DE ZORGSECTOR}

\subsection{Inleiding}

Dit hoofdstuk behandelt de belangrijkste arbeidsmarktontwikkelingen in de zorgsector vanaf het midden van de jaren tachtig. Eerst wordt de algemene ontwikkeling in de zorgsector in beeld gebracht. Hierbij staan de begrippen 'zorgbehoefte' en 'zorgvolume' centraal. Vervolgens worden enkele indicatoren gepresenteerd die meer zicht geven op de eventuele spanningen die zich vanaf het eind van de jaren tachtig op de arbeidsmarkt in de zorgsector hebben voorgedaan. In deze periode, waarin tot voor kort sprake was van een sterke economische groei, lijkt de zorgsector steeds vaker te zijn geconfronteerd met een aantal knelpunten op de arbeidsmarkt. De indicatoren die in beeld worden gebracht hebben enerzijds betrekking op eventuele kwantitatieve arbeidsmarktdiscrepancies, zoals moeilijk vervulbare vacatures en werkloosheid. Anderzijds gaat het om indicatoren die meer licht kunnen werpen op mogelijke kwalitatieve arbeidsmarktknelpunten, zoals onderbenutting van de kwalificaties waarover men beschikt, de ontwikkeling van de lonen, de ontwikkeling van het ziekteverzuim en het personeelsverloop. Tevens wordt ingegaan op de beeldvorming van het werk in de zorgsector onder jongeren.

Kwantitatieve en kwalitatieve arbeidsmarktknelpunten hangen overigens vaak samen: wanneer de werkloosheid in bepaalde beroepen hoog is, kunnen de werkgevers de nodige (aanvullende) eisen stellen, hetgeen vaak leidt tot verdringing van lager opgeleiden door hoger geschoolden. Dit kan weer leiden tot een hoog personeelsverloop en ziekteverzuim en een minder goede beeldvorming over het beroep. Bij een hoge werkloosheid zal bovendien de loonstijging waarschijnlijk gering zijn. Wanneer daarentegen sprake is van een lage werkloosheid en een groot aantal moeilijk te vervullen vacatures zullen bovengenoemde processen waarschijnlijk in omgekeerde zin plaatsvinden.

Vervolgens wordt in dit hoofdstuk getracht meer inzicht te geven in de achterliggende dynamiek van de gesignaleerde arbeidsmarktknelpunten in het recente verleden. Achtereenvolgens zal worden ingegaan op de werkgelegenheidsontwikkeling (uitbreidingsvraag), de ontwikkeling in het netto personeelsverloop (vervangingsvraag) en de recente ontwikkeling in de instroom van schoolverlaters in de zorgsector. Dit hoofdstuk vormt daarmee tevens een opstap naar de volgende hoofdstukken van het rapport, waarin wordt ingegaan op de toekomstige ontwikkelingen in vraag en aanbod op de arbeidsmarkt in de zorgsector.

\subsection{Zorgbehoefte en zorgvolume}

\section{Zorgbehoefte}

"Wanneer men een voorziening wil plannen of evalueren, zal men op z'n minst enig inzicht moeten hebben in de behoefte aan zorg binnen een populatie", geven Moons, Kerkstra en Picauly (1989, blz. 14) aan in het rapport De zorgbehoefte ontleed. Zij laten zien dat het behoeftebegrip diffuus is en op meerdere manieren kan worden geïnterpreteerd. In figuur 2.1 worden de relaties tussen behoefte, zorgbehoefte, de vraag naar en het gebruik van professio- 
nele zorgvoorzieningen en het aanbod hiervan, alsmede het beleid hierover in kaart gebracht. Het begrip behoefte verwijst naar een ongewenste (gezondheids)toestand van een individu, terwijl de zorgbehoefte wordt bepaald door de hoeveelheid zorg die nodig is om deze ongewenste toestand op te heffen. Hierbij kan een onderscheid worden gemaakt tussen het bredere 'behoefte aan zorg' en het smallere 'behoefte aan voorzieningen'. In de behoefte aan gezondheidszorg kan door verschillende 'zorgsystemen' worden voorzien: naast professionele zorgvoorzieningen zijn er ook zelfzorg, mantelzorg, vrijwilligers en particuliere zorgvoorzieningen. Hierbij dient men zich te realiseren dat de behoefte aan bijvoorbeeld thuiszorg, mede wordt bepaald door de verhouding tot de andere zorgvoorzieningen. Voor een deel gaat het hier om 'communicerende vaten', die overigens wel een verschillend prijskaartje kunnen hebben.

Figuur 2.1. De zorgbehoefte ontleed

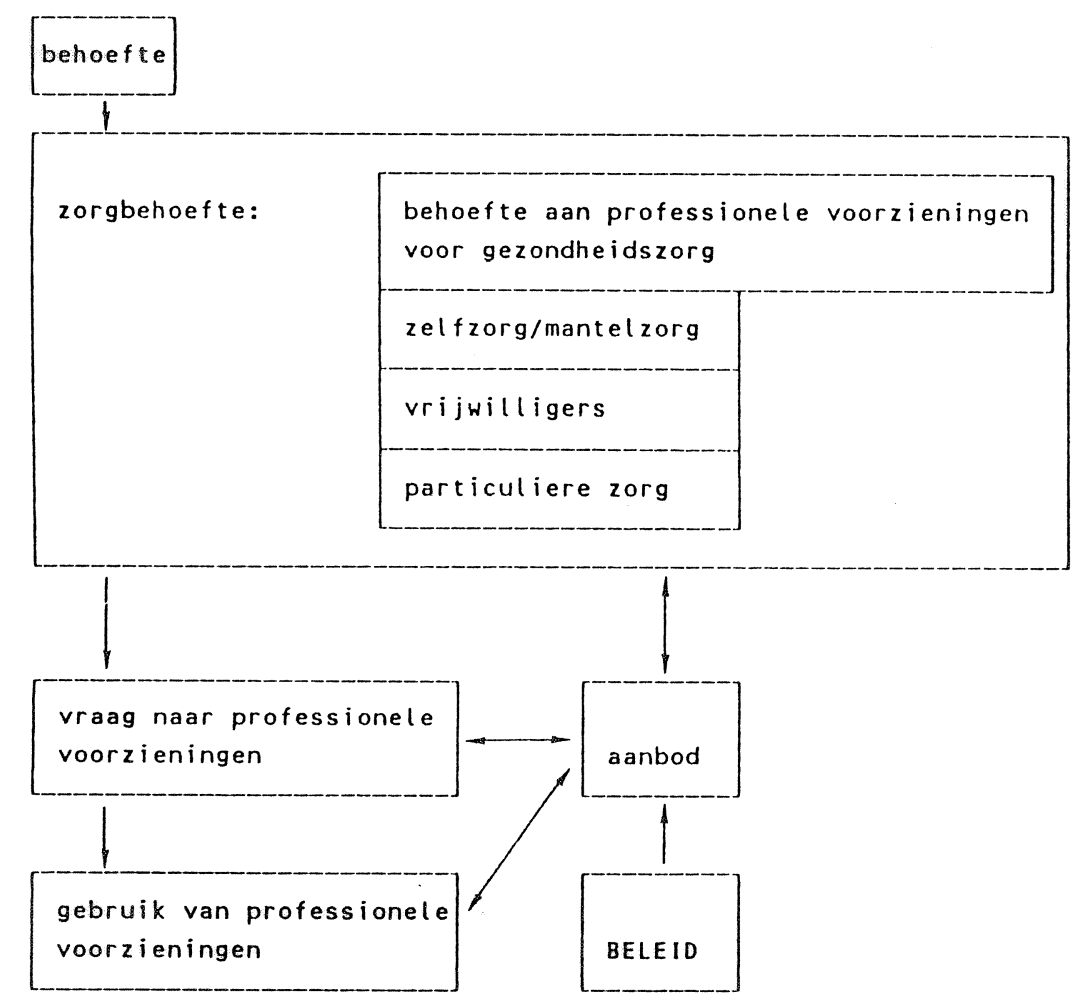

Bron: Moons, Kerkstra en Picauly (1989)

De zorgbehoefte is ook niet een verschijnsel dat zonder meer empirisch kan worden vastgesteld. Het is een abstractie die niet als zodanig concreet meetbaar is. Wat men dus verstaat onder zorgbehoefte is een beoordelingskwestie. Dit komt doordat het object van zorg, de gezondheid, een relatief begrip is. Wat gedefinieerd wordt als gezond of ongezond en waar de grenzen liggen van een ongewenste toestand, is gebaseerd op normen en waarden. Naast de aard en de ernst van een probleem is ook de noodzaak of geschiktheid van een voorziening een kwestie van beoordeling. Zorgbehoefte laat zich dan ook niet als een hard feit vaststellen (zie ook Moons, Kerkstra en Picauly, 1989 en Knox, 1979).

Afhankelijk van het perspectief dat men bij de beoordeling inneemt, kan men twee soorten behoeften onderscheiden. De objectieve behoefte is gebaseerd op criteria die zijn vastgesteld 
$-8-$

door deskundigen, terwijl de subjectieve behoefte uitgaat van de perceptie van de betrokkenen. Maar ook binnen deze groepen is een verschillend oordeel van de zorgbehoefte mogelijk. Zo kan er een verschil in subjectieve behoefte zijn tussen cliënten en hun omgeving, terwijl hulpverleners, onderzoekers en beleidsmakers verschil van mening kunnen hebben over de objectieve zorgbehoefte.

Desondanks onderscheiden Moons, Kelstra en Picauly (1989) vier methoden om de zorgbehoefte te bepalen:

- objectieve behoefte-bepaling: het bestaan van bepaalde gezondheidsproblemen bij de bevolking wordt als indicatie gebruikt voor de zorgbehoefte; deskundigen (hulpverleners) stellen dit vast;

- subjectieve behoefte-bepaling: betrokkenen geven aan of er, in hun perceptie, bepaalde gezondheidsproblemen zijn en/of hulp gewenst is;

- vraag naar voorzieningen: betrokkenen geven aan of, en zo ja, welk soort hulp zij verlangen;

- gebruik van voorzieningen: de mate waarin gebruik wordt gemaakt van de voorzieningen bepaalt de behoefte aan zorg.

Gegeven het doel van dit onderzoek, wordt ervoor gekozen het begrip zorgbehoefte verder uit te werken met behulp van de indicator 'gebruik van voorzieningen'. Het gebruik van (professionele) zorgvoorzieningen is immers het punt waar vraag naar en aanbod van voorzieningen samenkomen.

Van der Zwan, Van Dijk en Borst-Eilers (1993), die te zamen de Commissie Strategische Heroriëntatie Gezondheidszorg vormden, geven in hun rapport Gezondheidszorg in tel de volgende vijf verklarende factoren voor het - ook door hen gesignaleerde - toegenomen gebruik van gezondheidszorgvoorzieningen:

- door de vooruitgang in de medische wetenschap zijn de mogelijkheden voor behandeling en verzorging vergroot;

- de bevolking is meer waarde gaan hechten aan een goede gezondheid;

- de toegenomen welvaart heeft een groter beroep op de gezondheidszorgvoorzieningen mogelijk gemaakt;

- de politiek heeft een brede sociale toegankelijkheid bewerkstelligd;

- de vergrijzing van de bevolking heeft geleid tot een grotere zorgbehoefte, zowel in kwantitatieve zin als qua intensiteit.

Tabel 2.1 laat zien dat de toename van het gebruik van de gezondheidszorg, gedefinieerd als de geldelijke besteding aan gezondheidszorgvoorzieningen gerelateerd aan het Bruto Nationaal Produkt (BNP), zich met name tussen 1965 en 1975 heeft voorgedaan. Sinds 1980 is er sprake van een zekere stabilisatie van de bestedingen als percentage van het BNP. Van der Zwan, Van Dijk en Borst-Eilers (1993) wijten deze kentering onder andere aan de rolwisseling van de overheid van een stimulerende naar een regulerende rol. Bij deze regulering heeft de overheid met name pogingen ondernomen om de uitgaven te beperken door het aanbod van zorg meer in haar greep te krijgen. Regulering van de vraag is de overheid daarbij echter tot nu toe uit de weg gegaan. 
$-9-$

Tabel 2.1. Uitgaven aan gezondheidszorg als percentage van het BNP 1960-1990

\begin{tabular}{lrrrrrrr}
\hline & $\begin{array}{r}1960 \\
\%\end{array}$ & $\begin{array}{r}1965 \\
\%\end{array}$ & $\begin{array}{r}1970 \\
\%\end{array}$ & $\begin{array}{r}1975 \\
\%\end{array}$ & $\begin{array}{r}1980 \\
\%\end{array}$ & $\begin{array}{r}1985 \\
\%\end{array}$ & $\begin{array}{r}1990 \\
\%\end{array}$ \\
\hline Totaal gezondheidszorg & 3,9 & 4,4 & 6,0 & 7,6 & 8,0 & 8,0 & 8,1 \\
\hline
\end{tabular}

Bron: NZi, Program OECD HEALTH DATA OECD

Van der Zwan, Van Dijk en Borst-Eilers (1993, blz. 102) geven daarnaast aan dat "het spanningsveld tussen de mogelijkheden die de gezondheidszorg kent en het beroep dat hierop door patiënten wordt gedaan enerzijds en de voor die zorg beschikbaar komende middelen anderzijds, dwingt tot het maken van keuzen". Zij wijzen in dat verband naar het rapport Kiezen en delen van de Commissie Dunning (1991), waarin een 'trechter met vier zeven' wordt beschreven voor het toekennen van de schaarse middelen in de gezondheidszorg. Deze zeven betreffen de volgende criteria: noodzakelijkheid, werkzaamheid, doelmatigheid en collectieve financiering.

Verder pleit de Commissie Strategische Heroriëntatie Gezondheidszorg voor een hervorming van het financieringsstelsel voor het gebruik van zorgvoorzieningen. De band tussen het beroep dat op zorgvoorzieningen wordt gedaan en het (financiële) offer dat hiervoor moet worden gebracht, zou moeten worden hersteld, zodat niet alleen het financiële draagvlak van de gezondheidszorg wordt vergroot, maar eveneens de betrokkenheid van de bevolking bij een goede, toegankelijke en betaalbare gezondheidszorg.

\section{Zorgvolume}

Voor het bepalen van de produktiewaarde van de gezondheidszorg gaan Van der Zwan, Van Dijk en Borst-Eilers (1993) uit van het macrobudget van de instellingen, dat jaarlijks door de overheid wordt bepaald. Tabel 2.2 geeft voor de onderscheiden deelsectoren de ontwikkeling weer in de produktiewaarde tussen 1987 en 1992, op basis van de macro budgetgegevens uit het Financieel Overzicht Zorg (FOZ) van het Ministerie van Welzijn, Volksgezondheid en Cultuur (1992, 1993).

Uit de tabel blijkt dat de produktiewaarde van de zorgsector tussen 1987 en 1992 is toegenomen van bijna 27 miljard in 1987 tot ruim 34 miljard in 1992. Gemiddeld betekent dit een groei van bijna $5 \%$ per jaar. De gegevens over de produktiewaarde laten zien dat deze groei begin jaren negentig sterker is geweest dan eind jaren tachtig. De produktiewaarde is het sterkst toegenomen in de ziekenhuizen en de gehandicaptenzorg, terwijl de groei in de gezinszorg, het kruiswerk en de bejaardenoorden relatief aan de lage kant is gebleven.

De Commissie Strategische Heroriëntatie Gezondheidszorg geeft aan dat de kwaliteit van de (intramurale) gezondheidszorg de laatste jaren sterk is verbeterd. De volgende kernbegrippen staan daarbij centraal: micro-chirurgie, innovaties in manipulatie-instrumentarium en diagnos- 
tische (beeldvormende) apparatuur, korter en minder belastend genezingsproces, vaker dagbehandeling, vaker $1^{\mathrm{e}}$ lijnszorg aan huis vanuit de intramurale sector, multi-disciplinaire zorgteams, afstemming zorg op individuele behoeften, kleinere zorgeenheden, zelfstandigheid en bevordering van integratie.

Tabel 2.2. Uitgaven/budgetten per deelsector (in miljoenen guldens) 1987-1992

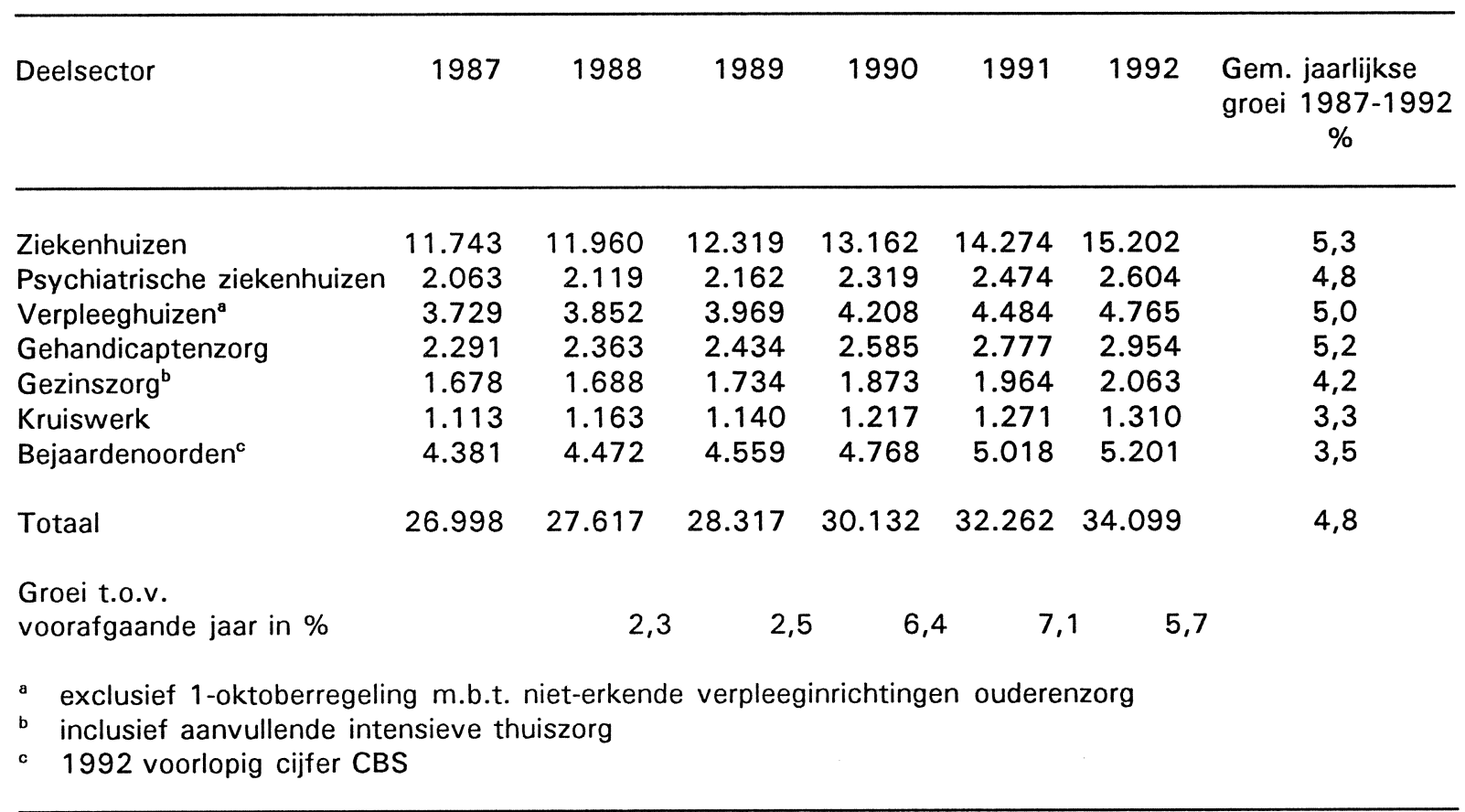

Bron: FOZ $(1993,1994)$

Vanwege de veelvormigheid van de activiteiten in de intra- en extramurale gezondheidszorg is het niet mogelijk om het zorgvolume met behulp van slechts één maatstaf weer te geven. Er zijn niet alleen grote verschillen in de aangeboden zorg tussen de onderscheiden deelsectoren, maar eveneens binnen deze sectoren. Zo bestaan er alleen binnen de ziekenhuizen al circa 2.000 verschillende verrichtingen (Van der Zwan, Van Dijk en Borst-Eilers, 1993).

Voor de intramurale gezondheidszorg heeft de Commissie Strategische Heroriëntatie Gezondheidszorg getracht het produktievolume in kaart te brengen door, naast het aantal verpleegdagen en verrichtingen, de volgende indicatoren te gebruiken (tussen haakjes is de ontwikkeling voor de desbetreffende indicator in de afgelopen jaren aangegeven):

- het aantal klinische en poliklinische verrichtingen per opname of polibezoek (toename);

- het aandeel $65^{+}$-ers (toename);

- aantal verpleegdagen per opname: de ligduur (afname);

- index voor hulpbehoevendheid: de mate waarin patiënten niet meer in staat zijn voor zichzelf te zorgen, wat betreft wassen, eten, aankleden e.d. (toename);

- het aantal verzorgers per bewoner (toename);

- aantal patiënten, (deeltijd)opnamen, polibezoeken, $1^{\mathrm{e}}$ consulten (toename). 
Voor de gezinszorg is als maatstaf voor de omvang van het produktievolume het totaal aantal produktieve uren voor de traditionele verzorgingstaken (dus exclusief de uren voor alpha-hulp) en het aandeel $65^{+}$-ers onder de cliënten gekozen. Gegevens over het aantal produktieve (traditionele) uren in de gezinszorg zijn over de jaren na 1990 niet meer beschikbaar. Voor de bepaling van het produktievolume in de wijkverpleging is gebruik gemaakt van gegevens over het aantal individuele contacten per 100 inwoners en het aandeel van $60^{+}$-ers in deze contacten $^{3}$. Bij de kraamcentra en de bejaardenoorden gaat het om het totaal aantal verzorgingsdagen, waarbij voor de bejaardenoorden eveneens de mate van hulpbehoevendheid is meegenomen. Na 1990 zijn er voor de kraamzorg geen cijfers meer voorhanden over het aantal verzorgingsdagen. Bij de wijkverpleging, de gezinszorg en de bejaardenoorden tellen de ontwikkelingen met betrekking tot de kwantitatieve indicatoren (de contacten, produktieve uren en verzorgingsdagen) steeds voor $90 \%$ mee en de ontwikkelingen in de kwalitatieve indicatoren (aandeel ouderen, mate van hulpbehoevendheid) iedere keer voor $10 \%$. De ontwikkeling in het produktievolume is weergegeven in tabel 2.3. Ten aanzien van de sector kruiswerk is daarbij een onderscheid gemaakt tussen het kruiswerk en de kraamzorg.

Tabel 2.3. Ontwikkeling produktievolume per deelsector, 1985-1992 (gemiddelde jaarlijkse groei)

\begin{tabular}{|c|c|c|c|c|c|c|c|c|}
\hline Deelsector & $\begin{array}{r}1985 \\
\%\end{array}$ & $\begin{array}{r}1986 \\
\%\end{array}$ & $\begin{array}{r}1987 \\
\%\end{array}$ & $\begin{array}{r}1988 \\
\%\end{array}$ & $\begin{array}{r}1989 \\
\%\end{array}$ & $\begin{array}{r}1990 \\
\%\end{array}$ & $\begin{array}{r}1991 \\
\%\end{array}$ & $\begin{array}{r}1992 \\
\%\end{array}$ \\
\hline Ziekenhuizen & 0,6 & $-0,4$ & 0,5 & 1,7 & 2,7 & 1,7 & 2,7 & 3,2 \\
\hline Psychiatrische ziekenhuizen & 0,4 & 2,9 & 2,6 & 2,8 & 2,2 & 3,1 & 5,1 & 3,0 \\
\hline Verpleeghuizen & 2,4 & 1,7 & 2,0 & 2,2 & 1,5 & 1,3 & 2,4 & 2,6 \\
\hline Gehandicaptenzorg $^{a}$ & 1,4 & 2,1 & 1,2 & 2,6 & 2,5 & 3,2 & 2,7 & 2,9 \\
\hline Gezinszorg & & $-3,1$ & & $-0,7$ & $-1,1$ & 4,3 & & \\
\hline Wijkverpleging & & 1,6 & $-2,1$ & 1,6 & & 3,9 & 2,2 & 2,1 \\
\hline Kraamzorg & & 1,9 & 1,7 & 1,5 & 0,9 & 0,7 & & \\
\hline Bejaardenoorden & & $-0,5$ & $-0,8$ & $-0,3$ & $-0,6$ & $-1,5$ & $-0,9$ & \\
\hline
\end{tabular}

a De gehandicaptenzorg heeft in deze tabel alleen betrekking op de instellingen voor verstandelijk gehandicapten.

Bron: Van der Zwan, Van Dijk en Borst-Eilers (1993), FOGM/FOZ (1987-1994), CBS, LVT, ROA

Het produktievolume blijkt in de meeste zorgsectoren de afgelopen jaren te zijn gegroeid. In het algemeen is deze groei in het begin van de jaren negentig sterker dan halverwege de jaren tachtig. In de bejaardenoorden is de omvang van de zorg licht afgenomen, ondanks een correctie voor het toenemende aantal (zwaar) hulpbehoevenden. Eind jaren tachtig is het produktievolume bij de gezinszorg gedaald, maar in 1990 is er in deze sector sprake geweest van een forse groei. In aanvulling op de in de tabel gepresenteerde cijfers kan worden opgemerkt dat tussen 1990 en 1992 het aantal cliënten in de gezinszorg met gemiddeld 5,5\% per jaar is toegenomen. Bij de ziekenhuizen is de toename van het produktievolume het gevolg van de toegenomen intensiteit

3. Deze gegevens zijn ontleend aan het rapportagegedeelte van het wijkadministratiesysteem (WAS), welke is gebaseerd op een steekproef die circa $70 \%$ van de Nederlandse bevolking omvat. Het betreft hier alleen de individueel gerichte curatieve zorgverlening. De preventieve zorg en de consultatie-werkzaamheden vallen hier buiten. 
van de behandelingen. Het aantal verpleegdagen is in de sector de afgelopen jaren fors afgenomen. Ook bij de gezinszorg en de bejaardenoorden is er in kwantitatieve zin sprake van een afname van het produktievolume. Bij de verpleeghuizen, de gehandicaptenzorg, het kruiswerk en de kraamzorg is daarentegen in kwantitatieve zin sprake van een (forse) toename van het produktievolume. Het aantal verpleegdagen bij de psychiatrische ziekenhuizen heeft de afgelopen jaren enigszins gefluctueerd. Tot slot wordt opgemerkt dat Van der Zwan, Van Dijk en Borst-Eilers constateren dat in de intramurale gezondheidszorg het produktievolume de afgelopen jaren sterker is gestegen dan de inzet van produktiefactoren. Zij komen derhalve tot de conclusie dat er tussen 1982 en 1992 in deze zorgsectoren sprake is geweest van een produktiviteitsstijging van gemiddeld circa $0,7 \%$ per jaar.

Bovengeschetste ontwikkelingen in het produktievolume weerspiegelen het gezondheidszorgbeleid van de afgelopen jaren, evenals de mede daardoor gewijzigde taakverdeling tussen de onderscheiden deelsectoren binnen de zorg. De ziekenhuizen trachten het aantal verplegingsdagen per patiënt zoveel mogelijk terug te brengen, zodat patiënten kortere tijd in de instelling hoeven verblijven. Terwijl het herstel van ziekenhuispatiënten voorheen in de ziekenhuizen zèlf plaatsvond, wordt deze taak overgenomen door met name de verpleeghuizen. Daarnaast gaan patiënten die nog enkel rust dienen te houden eerder naar huis, waarbij dan eventueel een beroep kan worden gedaan op hulp vanuit de gezinszorg of het kruiswerk. Hetzelfde geldt voor patiënten waarbij men verdere medische hulp niet (meer) mogelijk of zinvol acht. Deze ontwikkeling wordt ook wel eens aangeduid als het verdwijnen van de 'hotelfunctie' van de ziekenhuizen.

Dit heeft wel tot gevolg dat de wel aanwezige patiënten meer zorg nodig hebben dan voorheen. Doordat de (psychiatrische) ziekenhuizen, met name sinds het begin van de jaren negentig, een deel van de zorgtaken doorschuiven naar verpleeghuizen en extramurale instellingen, neemt het beroep op de verpleeghuizen en extramurale dienstverlening toe, waardoor ook in deze laatste sectoren alleen nog hulp kan worden geboden aan de meest hulpbehoevenden. Bovendien heeft de kwaliteitsverbetering van de zorgverlening eveneens geleid tot een intensievere werkbelasting van het personeel. Men zou kunnen zeggen dat de zorgverlening de afgelopen jaren sterk is 'geïntensiveerd', hetgeen vooral heeft geleid tot een toegenomen werkdruk in kwalitatieve zin.

Ook de functie van de bejaardenoorden is de afgelopen jaren aanzienlijk veranderd. Voorheen hadden de bejaardenoorden in de eerste plaats een functie als 'gezamenlijk woonoord' voor ouderen, waarbij huishoudelijke taken (inclusief maaltijdbereiding) voor een belangrijk deel door het bejaardenoord werden verzorgd. Nu ouderen, zo lang de gezondheid het toelaat, vaker zelfstandig willen blijven wonen, is de behoefte aan deze vorm van bejaardenzorg onder de gezonde en relatief jonge bejaarden gedaald en is daarmee tevens de grens tussen verpleeghuizen en bejaardenoorden vervaagd.

\subsection{Monitoring arbeidsmarktknelpunten en imago gezondheidszorg}

$\mathrm{Na}$ in de vorige paragraaf een algemeen beeld te hebben geschetst van de ontwikkelingen in de zorgsector in de afgelopen jaren, wordt in deze paragraaf een aantal indicatoren gepresenteerd 
voor het in kaart brengen ('monitoren') van mogelijke arbeidsmarktknelpunten in de zorgsector. Eerst wordt ingegaan op de kwantitatieve knelpunten (moeilijk vervulbare vacatures, werkloosheid), daarna komen de kwalitatieve knelpunten op de arbeidsmarkt aan bod (onderbenutting en verdringing, inkomen, ziekteverzuim, potentiële baanmobiliteit, bruto personeelsverloop, beeldvorming van het werken in de zorgsector onder jongeren).

\section{Moeilijk vervulbare vacatures}

Knelpunten in de personeelsvoorziening kunnen onder meer aan de hand van het percentage moeilijk vervulbare vacatures worden afgemeten. Tabel $2.4 \mathrm{a}$ geeft een overzicht van het percentage moeilijk vervulbare vacatures op 31 december 1991 in de vier deelsectoren binnen de intramurale zorgverlening. Helaas zijn geen gegevens beschikbaar van het totaal aantal vacatures op dat moment, zodat het aantal moeilijk vervulbare vacatures alleen gerelateerd kan worden aan het totaal aantal arbeidsplaatsen. Uit de tabel blijkt dat binnen de intramurale gezondheidszorg het percentage moeilijk vervulbare vacatures bij de gehandicaptenzorg het laagst is. Voor het kruiswerk en de gezinszorg zijn helaas geen gegevens over moeilijk vervulbare vacatures voorhanden. Voor de bejaardenoorden zijn wel enige gegevens over moeilijk vervulbare vacatures bekend. Het gaat hier echter om het aantal moeilijk of niet vervulbare vacatures tussen half mei 1990 en half mei 1991 (Thomassen en Van der Vange, 1991). In deze periode blijkt $18 \%$ van het totaal aantal vacatures moeilijk of in het geheel niet vervulbaar te zijn geweest. Omgerekend betreft dit 3,6\% van het totaal aantal bezette arbeidsplaatsen eind 1991. Uitdrukkelijk wordt opgemerkt dat dit percentage, dat betrekking heeft op het aantal moeilijk vervulbare vacatures over de periode van een geheel jaar, niet vergelijkbaar is met de in tabel 2.4a gepresenteerde cijfers die betrekking hebben op het aantal moeilijk vervulbare vacatures op een bepaald moment.

Tabel 2.4a. Moeilijk vervulbare vacatures in procenten van het totaal aantal bezette arbeidsplaatsen per deelsector in de intramurale gezondheidszorg 31 december 1991

Deelsector

Moeilijk vervulbare vacatures

$\%$

$\begin{array}{lr}\text { Ziekenhuizen } & 0,6 \\ \text { Psychiatrische ziekenhuizen } & 0,8 \\ \text { Verpleeghuizen } & 0,7 \\ \text { Gehandicaptenzorg }^{\mathrm{a}} & 0,3\end{array}$

a De gehandicaptenzorg heeft in deze tabel alleen betrekking op de zwakzinnigenzorg.

Bron: NZi Statistiek Personeelssterkte

Verder blijken er tussen de verschillende regio's grote verschillen te bestaan in het aandeel moeilijk vervulbare vacatures (zie Gerritse, Van den Heuij en Van der Windt, 1993 en Thomassen en Van der Vange, 1991). Vooral in de Randstad is de personeelsvoorziening vaak moeizaam geweest. Het relatief geringe percentage moeilijk vervulbare vacatures in de andere regio's duidt er op dat de bereidheid van (potentiële) beroepskrachten om te gaan werken in 
gezondheidszorginstellingen in grote steden naar verhouding klein is, waardoor de knelpunten zich met name manifesteren in de grootstedelijke gebieden.

Tabel 2.4b. Moeilijk vervulbare vacatures in procenten van het totaal aantal vacatures ${ }^{a}$ per ROA-beroepsklasse, september 1992

a Exclusief vacatures bij overheid, onderwijs, sociale werkplaatsen, uitzendbureaus en uitleenbedrijven

Bron: CBS, ROA

Ook door het Centraal Bureau voor de Statistiek (CBS) wordt regelmatig een vacature-enquête gehouden (zie ook Klaver en Sprangers, 1990). In tabel 2.4b is een overzicht gegeven van het percentage moeilijk vervulbare vacatures in het totaal aantal vacatures naar ROAberoepsklasse $^{4}$ in september 1992. De beoordeling of een vacature moeilijk vervulbaar is of niet, heeft het CBS aan de responderende bedrijven zelf overgelaten. De tabel laat zien dat in het algemeen ruim één op de drie vacatures als moeilijk vervulbaar kan worden aangemerkt. In de zorgsector blijkt vooral de werving van leerling-verpleegkundigen, zieken- en kraamverzorgenden relatief moeizaam te verlopen.

\section{Werkloosheid}

Naast de gegevens over moeilijk vervulbare vacatures is voor het meten van kwantitatieve knelpunten op de arbeidsmarkt de werkloosheid onder schoolverlaters relevant. Het ROA verricht periodiek onderzoek onder de schoolverlaters van het algemeen voortgezet onderwijs, het $\mathrm{VBO}$ en het MBO, alsmede onder de afgestudeerden van het HBO. Dit betreft respectievelijk de enquête-onderzoeken Registratie Uitstroom en Bestemming van Schoolverlaters (RUBS) (zie Wieling, Van de Loo en Van der Velden, 1993) en HBO-Monitor (zie Van de Loo, Van der Velden en Wieling, 1993). Voor de zorgsector zijn met name de gegevens over de schoolverlaters van het $\mathrm{MBO}$ en het $\mathrm{HBO}$ relevant. Daarbij wordt aangetekend dat de schoolverlaters van het MBO circa één jaar na het verlaten van de opleiding geënquêteerd zijn, terwijl de afgestudeerden van het $\mathrm{HBO}$ ongeveer anderhalf jaar na afstuderen worden geënquêteerd. Vergelijkbare gegevens over de schoolverlaters van het inservice-onderwijs en het leerlingwezen zijn helaas niet beschikbaar.

4. Voor een toelichting op de ROA-beroepsklassen wordt verwezen naar Van de Loo, Dekker en De Grip (1992). 
Tabel 2.5. Intredewerkloosheid en werkloosheid tijdens enquête onder gediplomeerde schoolverlaters naar opleidingsrichting 1992

\begin{tabular}{lcc}
\hline Opleiding & Intredewerkloosheid & \multicolumn{2}{c}{ Werkloosheid } \\
& $\%$ & 2 \\
\hline DGO-L-vp & & 2 \\
DGO-L-vZ & 14 & 4 \\
Totaal MBO & 16 & 3 \\
HBO-v & 17 & 3 \\
HBO-mgz & 25 & 11 \\
Totaal HBO & 18 & 21 \\
\hline
\end{tabular}

Bron: RUBS 1992, HBO-Monitor 1992, ROA

In tabel 2.5 zijn twee maten voor de werkloosheid onder de gediplomeerde schoolverlaters van het schooljaar 1990/1991 opgenomen. De intredewerkloosheid heeft betrekking op het percentage gediplomeerde schoolverlaters dat na de opleiding werkzoekend is (geweest) alvorens een baan te hebben gevonden. Daarnaast is in de tabel het werkloosheidspercentage ten tijde van de meting weergegeven. Uit de tabel blijkt dat de intredewerkloosheid en de werkloosheid ten tijde van de meting voor de gediplomeerden van de verpleegkundige HBOopleidingen (relatief) laag zijn. Ook de (intrede)werkloosheid bij verplegende en verzorgende opleidingen op MBO-niveau is verhoudingsgewijs laag. Dit duidt op een gespannen arbeidsmarkt in de zorgsector, waardoor bij de verschillende zorginstellingen gemakkelijk knelpunten in de personeelsvoorziening kunnen optreden.

\section{Aansluiting opleiding-beroep}

Spanningen op de arbeidsmarkt komen niet alleen tot uiting in kwantitatieve knelpunten, maar evenzeer in kwalitatieve aansluitingsproblemen. Belangrijk is in dit verband de mate waarin de banen waarin gediplomeerden van verpleegkundige en verzorgende opleidingen terecht komen, aansluiten bij het niveau en de richting van de door hen gevolgde opleiding. Indien het functieniveau onder het gevolgde opleidingsniveau ligt, wijst dat op een potentiële onderbenutting van de capaciteiten waarover men beschikt. Daarbij moet echter worden opgemerkt dat de beschikbare informatie doorgaans betrekking heeft op startfuncties. Een deel van de gediplomeerden, die in eerste instantie onder hun niveau werk vinden, zal mogelijk op termijn doorgroeien naar een functieniveau dat wel aansluit bij het niveau van de gevolgde opleiding (zie ook De Grip, Heijke en Willems, 1992). Desalniettemin geeft een hoog onderbenuttingspercentage ter dege een indicatie van een slechte arbeidsmarktpositie voor de schoolverlaters van de desbetreffende opleiding.

Verdringingsprocessen op de arbeidsmarkt en de 'onderbenutting' die daarvan het gevolg is, hangen nauw samen met de kwantitatieve ontwikkelingen op de arbeidsmarkt. Wanneer er sprake is van een ruime arbeidsmarkt, waarbij het aanbod de vraag naar bepaalde beroepskrachten ruimschoots overtreft, verdringen hoger opgeleiden vaak de lager geschoolden in 
functies die voorheen door hen werden vervuld. Is daarentegen de arbeidsmarkt erg krap, dan treden deze processen in omgekeerde zin op: lager opgeleiden worden aangenomen in functies waarvoor voorheen hoger gekwalificeerden in aanmerking kwamen. Via interne opleidingen trachten werkgevers het aangetrokken personeel vervolgens bij te scholen om hen op het voor de functies vereiste niveau te brengen.

Uit tabel 2.6 kan men opmaken dat in het algemeen veel gediplomeerden van de verpleegkundige en verzorgende $\mathrm{MBO}$ - en HBO-opleidingen werk hebben gevonden dat wat betreft niveau en richting goed aansluit bij de door hen gevolgde opleiding. De afgestudeerden van het HBO-v vormen hierop echter een uitzondering. Slechts voor $69 \%$ van de schoolverlaters die een baan hebben gevonden betreft dit werk dat qua niveau aansluit bij de gevolgde opleiding. Uit het feit dat wel bijna alle afgestudeerden van het HBO-v werkzaam zijn in een functie waarvoor de eigen of een verwante opleidingsrichting werd gevraagd, kan worden geconcludeerd dat de afgestudeerden van het HBO-v waarschijnlijk nogal eens werkzaam zijn in verpleegkundige beroepen op voornamelijk uitvoerend niveau.

Tabel 2.6. Percentage werkende schoolverlaters met werk aansluitend op eigen of hoger niveau, respectievelijk werk in de eigen richting, naar opleidingsrichting 1992

\begin{tabular}{lcr} 
Opleiding & $\begin{array}{c}\text { werk op aansluitend } \\
\text { of hoger niveau } \\
\%\end{array}$ & $\begin{array}{c}\text { werk in } \\
\text { vakrichting } \\
\%\end{array}$ \\
\hline DGO-L-vp & 89 & 70 \\
DGO-L-vz & 85 & 62 \\
Totaal MBO & 78 & 51 \\
HBO-v & & 96 \\
HBO-mgz & 69 & 97 \\
Totaal HBO & 82 & 84 \\
\hline
\end{tabular}

Bron: RUBS 1992, HBO-Monitor 1992, ROA

Loon- en inkomensontwikkeling

De ontwikkeling in de zogenaamde 'regelingslonen' (de CAO-lonen) weerspiegelt de economische situatie op dat moment in het algemeen en van de betreffende sector in het bijzonder. Zijn er veel moeilijk te vervullen vacatures en dus arbeidsmarktspanningen in een bepaalde sector, dan staan de (reële) lonen veelal onder druk. Bij een hoge werkloosheid in een bepaalde sector of beroepscategorie nemen de (reële) lonen daarentegen niet of slechts in geringe mate toe. In de zorgsector spelen bij de loonontwikkelingen de bestedingsmogelijkheden van de overheid daarnaast een belangrijke rol. In tabel 2.7 is de (nominale) ontwikkeling in de regelingsIonen tussen 1985 en 1992 weergegeven voor werknemers in particuliere bedrijven, bij de overheid en in de gepremieerde en gesubsidieerde sector (de 'trendvolgers'). Bij deze laatste categorie zijn de gegevens voor de gezondheidszorg en de maatschappelijke dienstverlening en sociaal-culturele instellingen afzonderlijk vermeld. 
Tabel 2.7. Ontwikkeling in regelingslonen van volwassen werknemers per uur, inclusief toeslagen, vakantietoeslag en andere bijzondere uitkeringen, per bedrijfssector 1985-1992 (index: $1980=1001$

\begin{tabular}{|c|c|c|c|c|c|c|c|c|}
\hline Bedrijfssector & 1985 & 1986 & 1987 & 1988 & 1989 & 1990 & 1991 & 1992 \\
\hline Particuliere bedrijven & 121,0 & 123,3 & 124,7 & 126,1 & 128,1 & 131,9 & 137,2 & 143,3 \\
\hline $\begin{array}{l}\text { Overheid } \\
\text { Gepremieerde en }\end{array}$ & 98,2 & 100,7 & 102,1 & 102,4 & 104,3 & 108,1 & 111,6 & 115,6 \\
\hline $\begin{array}{l}\text { gesubsidieerde sector } \\
\text { - gezondheidszorg }\end{array}$ & $\begin{array}{l}106,6 \\
108,8\end{array}$ & $\begin{array}{l}109,6 \\
111,8\end{array}$ & $\begin{array}{l}110,4 \\
112,2\end{array}$ & $\begin{array}{l}111,5 \\
113,1\end{array}$ & $\begin{array}{l}113,6 \\
115,9\end{array}$ & $\begin{array}{l}118,1 \\
120,3\end{array}$ & $\begin{array}{l}121,8 \\
124,5\end{array}$ & $\begin{array}{l}126,5 \\
129,4\end{array}$ \\
\hline culturele instellingen & 106,5 & 108,1 & 108,6 & 109,7 & 111,4 & 115,8 & 118,9 & 123,6 \\
\hline Totaal & 113,7 & 116,1 & 117,4 & 118,5 & 120,5 & 124,4 & 129,0 & 134,4 \\
\hline
\end{tabular}

Bron: CBS

Tussen 1980 en 1992 zijn de CAO-Ionen, over alle sectoren te zamen, met ruim éénderde toegenomen. Voor de werknemers in de particuliere bedrijven is het CAO-loon in deze gehele periode meer gestegen, dan voor de werknemers die bij de overheid of als trendvolger werkzaam zijn, waardoor de loonverschillen tussen deze sectoren het afgelopen decennium zijn toegenomen. Binnen de gepremieerde en gesubsidieerde sector is de loonontwikkeling bij de gezondheidszorg sterker geweest dan bij de maatschappelijke dienstverlening en sociaalculturele instellingen. Het loon neemt sinds het begin van de jaren negentig in versneld tempo toe.

Tabel 2.8. Ontwikkeling gemiddeld maandsalaris per deelsector 1985-1992

\begin{tabular}{|c|c|c|c|c|c|c|c|c|}
\hline Deelsector & 1985 & 1986 & 1987 & 1988 & 1989 & 1990 & 1991 & 1992 \\
\hline Ziekenhuizen & - & - & 3.178 & - & - & - & - & 4.035 \\
\hline Psych. ziekenhuizen & - & - & 3.167 & - & - & - & - & 4.048 \\
\hline Verpleeghuizen & - & - & 2.763 & - & - & - & - & 3.516 \\
\hline Gehandicaptenzorg & - & - & 2.865 & - & - & - & - & 3.654 \\
\hline Gezinszorg & 2.831 & 3.018 & 3.110 & 3.202 & 3.217 & 3.405 & - & - \\
\hline Kruiswerk & 2.951 & 2.978 & 2.979 & 3.052 & 3.062 & 3.272 & - & - \\
\hline Bejaardenoorden & 2.960 & 2.968 & 3.082 & 3.136 & 3.238 & 3.468 & 3.463 & - \\
\hline
\end{tabular}

Bron: NZi, LVT, CBS, ROA

Voor de in dit onderzoek onderscheiden deelsectoren in de zorgsector zijn de ontwikkelingen in de feitelijk verdiende bruto maandsalarissen door het verplegend en verzorgend personeel weergegeven in tabel 2.8. Tussen 1987 en 1992 blijkt het gemiddelde maandsalaris (inclusief onregelmatigheidstoeslag), omgerekend naar een voltijdse werkweek, voor het totale verpleeg- 
kundig en verzorgend personeel in de intramurale gezondheidszorg ${ }^{5}$ met ongeveer een kwart te zijn toegenomen. Hoewel het groeipercentage voor alle deelsectoren vrijwel gelijk is, is de absolute toename van het gemiddelde maandsalaris in de ziekenhuizen en de psychiatrische ziekenhuizen het grootst, zodat het verschil met de beide andere intramurale deelsectoren in deze periode eveneens is toegenomen. De toename is deels het gevolg van loonstijgingen en vloeit deels ook voort uit het feit dat het personeel inmiddels in een hogere salarisschaal terecht is gekomen. De toename is slechts voor een klein deel toe te schrijven aan een toename van de inkomsten die via de onregelmatigheidstoeslag worden verdiend.

In de gezinszorg zijn de bruto maandelijkse salariskosten ${ }^{6}$ (inclusief werkgeverslasten), omgerekend naar een voltijdse werkweek, voor het verzorgend en helpend personeel tussen 1985 en 1990 licht toegenomen. Tussen 1989 en 1990 is de toename overigens sterker. Uit de tabel blijkt verder dat de gemiddelde salarissen in het kruiswerk tussen 1985 en 1990 licht zijn toegenomen. In 1990 is deze toename versterkt. Hierbij dient wel te worden opgemerkt, dat in 1984 een algemene loonsverlaging van $3 \%$ heeft plaatsgevonden. Dit betekent dat, gemiddeld gezien, het meeste (uitvoerende) personeel pas rond 1988 nominaal hetzelfde verdiende als in 1983. Ook in de bejaardenoorden zijn de gemiddelde bruto salariskosten per arbeidsplaats tussen 1985 en 1991 gestegen?. Het betreft de ontwikkeling in de salariskosten voor het totale personeel in de bejaardenoorden. In deze periode bedraagt de toename 17\%. In 1991 zijn de gemiddelde salariskosten overigens licht gedaald.

Hierboven is de salarisontwikkeling voor al het verpleegkundige en verzorgende personeel in de deelsectoren in de zorgsector weergegeven. Hieronder wordt voor de gediplomeerde schoolverlaters van MBO- en HBO-(gezondheidszorg)opleidingen aangegeven welk inkomen zij in 1992 per maand verdienden. Voor (potentieel aankomende) leerlingen van gezondheidszorgopleidingen is het natuurlijk bij het maken van een studie- of beroepskeuze van belang om te weten welk inkomen zij kunnen gaan verdienen, wanneer zij deze opleiding verlaten om in de zorgsector te gaan werken. Voor de concurrentiepositie van de zorgsector op de arbeidsmarkt voor nieuwkomers is het vooral ook van belang hoe de salarissen van de schoolverlaters van de gezondheidszorgopleidingen zich verhouden tot die van de andere opleidingen. In tabel 2.9 wordt het feitelijk verdiende maandinkomen van de schoolverlaters gepresenteerd. De inkomensgegevens van de MBO'ers hebben betrekking op het netto loon; bij de HBO'ers gaat het om het bruto loon.

5. Bij de deelsector ziekenhuizen zijn de salarisgegevens exclusief die van de academische ziekenhuizen.

6. Berekend als de kosten voor het salaris van uitvoerend personeel (exclusief alpha-hulp) gedeeld door het aantal arbeidsplaatsen (f.t.e.'s) aan het eind van het jaar. Dit bedrag is vervolgens gedeeld door 12 (maanden). Vertekening kan ontstaan wanneer in één jaar het aantal personeelsleden sterk stijgt of daalt.

7. Berekend als de (jaarlijkse) kosten voor salarissen en vergoedingen gedeeld door 12 (maanden) en vervolgens door het aantal arbeidsplaatsen op 31 december. Vertekening kan ontstaan wanneer in één jaar het aantal personeelsleden sterk stijgt of daalt. 
Tabel 2.9. Maandinkomen van werkende schoolverlaters naar opleidingsrichting 1992

\begin{tabular}{lcc}
\hline Opleiding & $\begin{array}{l}\text { Netto maandinkomen } \\
\text { in guldens }\end{array}$ & $\begin{array}{l}\text { Bruto maandinkomen } \\
\text { in guldens }\end{array}$ \\
\hline DGO-L-vp & 1.720 & \\
DGO-L-vZ & 1.616 & \\
Totaal MBO & 1.499 & 2.948 \\
HBO-v & & 3.348 \\
HBO-mgz & & 3.269 \\
Totaal HBO & & \\
\hline
\end{tabular}

Bron: RUBS 1992, HBO-Monitor 1992, ROA

De inkomensgegevens uit tabel 2.9 geven aan dat op MBO-niveau degenen met een verpleegkundig of verzorgend diploma een hoger maandinkomen en uurloon verdienen dan gemiddeld door de werkende schoolverlaters van het MBO wordt verdiend. Op HBO-niveau verdienen de afgestudeerde HBO-v'ers minder dan gemiddeld. Daarentegen verdienen de afgestudeerden HBO-mgz meer dan het gemiddelde voor de HBO-afgestudeerden. Deze hogere lonen zijn het gevolg van het feit dat de HBO-mgz-opleiding alleen open staat voor gediplomeerden van de inservice-opleidingen, waardoor de afgestudeerden in het algemeen ouder zijn en over relevante werkervaring beschikken.

\section{Ontwikkeling ziekteverzuim}

Tabel 2.10. Ziekteverzuim (incl. en excl. bevallingsverlof) per deelsector 1987-1992

\begin{tabular}{|c|c|c|c|c|c|c|}
\hline \multirow[t]{2}{*}{ Deelsector } & \multicolumn{3}{|c|}{$\begin{array}{c}\text { Verzuim } \\
\text { (incl. bevallingsverlof) }\end{array}$} & \multicolumn{3}{|c|}{$\begin{array}{c}\text { Verzuim } \\
\text { (excl. bevallingsverlof) }\end{array}$} \\
\hline & $\begin{array}{c}1987 \\
\%\end{array}$ & $\begin{array}{c}1990 \\
\%\end{array}$ & $\begin{array}{c}1992 \\
\%\end{array}$ & $\begin{array}{c}1987 \\
\%\end{array}$ & $\begin{array}{c}1990 \\
\%\end{array}$ & $\begin{array}{c}1992 \\
\%\end{array}$ \\
\hline Ziekenhuizen & 7,1 & 8,3 & 8,0 & 6,4 & 7,0 & 6,4 \\
\hline Psychiatrische ziekenhuizen & 6,9 & 9,4 & 9,3 & 6,3 & 8,3 & 7,9 \\
\hline Verpleeghuizen & 8,4 & 10,8 & 10,1 & 7,7 & 9,5 & 8,3 \\
\hline Gehandicaptenzorg $^{a}$ & 7,5 & 9,1 & 8,7 & 6,7 & 7,8 & 7,0 \\
\hline Gezinszorg & 10,1 & 10,5 & 9,8 & 9,6 & 9,7 & 8,8 \\
\hline Kruiswerk & 6,7 & 9,4 & 9,1 & 5,8 & 7,6 & 7,0 \\
\hline Bejaardenoorden & 8,0 & 9,4 & 8,7 & 7,4 & 8,1 & 7,3 \\
\hline Totaal zorgsector & 7,6 & 8,9 & 8,1 & 6,9 & 7,7 & 6,7 \\
\hline
\end{tabular}

Bron: BVG

De gegevens over het ziekteverzuim geven eveneens een indicatie van mogelijke knelpunten op de arbeidsmarkt in de zorgsector, met name voor zover die betrekking hebben op de kwaliteit van het werk. Uit tabel 2.10 blijkt dat het ziekteverzuimpercentage (exclusief bevallingsverlof) 
eind jaren tachtig is toegenomen, maar begin jaren negentig weer is gedaald. Deze ontwikkeling doet zich in alle deelsectoren voor. Alleen in de gezinszorg is het verzuimpercentage inmiddels onder het niveau van 1987 gedaald. Het verzuimpercentage in de gezinszorg is echter naar verhouding nog steeds hoog. Ook in de verpleeghuizen is het verzuim relatief hoog. Daarentegen is het verzuimpercentage bij de ziekenhuizen het laagst van alle deelsectoren.

\section{Potentiële baanmobiliteit}

Wanneer een verhoudingsgewijs hoog percentage nieuwkomers op een bepaald arbeidsmarktsegment op zoek is naar een andere baan, kan dit op instabiele arbeidsrelaties en mogelijk ook op relatief veel arbeidsonvrede duiden. Een laag percentage werkenden dat op zoek is naar een andere baan kan daarentegen op een relatief sterke arbeidsmarktpositie van deze werkenden wijzen en een grotere tevredenheid met de baan die men heeft.

Tabel 2.11 laat zien dat de werkende schoolverlaters van de verpleegkundige en verzorgende MBO- en HBO-opleidingen in vergelijking met de andere $\mathrm{MBO}^{\prime}$ ers en $\mathrm{HBO}^{\prime}$ ers minder vaak op zoek zijn naar een andere baan. De hoge mate van baantevredenheid stemt overeen met de naar verhouding sterke arbeidsmarktpositie die de gediplomeerden van de verpleegkundige en verzorgende opleidingen in 1992 hadden. Daar komt echter wel bij dat er in de zorgsector ook weinig variatie in de arbeidsvoorwaarden bestaat, waardoor het veranderen van werkgever binnen de deelsector doorgaans weinig aantrekkelijk is. Bovendien zijn de uitwijkmogelijkheden naar andere beroepsdomeinen en/of sectoren voor mensen met een verpleegkundig of verzorgend diploma gering (zie onder meer Wieling, Van de Loo en Van der Velden, 1993 en Van de Loo, Van der Velden en Wieling, 1993).

Tabel 2.11. Percentage werkende schoolverlaters dat op zoek is naar ander werk naar opleidingsrichting 1992

Opleiding
Op zoek naar ander werk

$\%$

$\begin{array}{lr}\text { DGO-L-vp } & 13 \\ \text { DGO-L-vz } & 8 \\ \text { Totaal MBO } & 20 \\ & \\ \text { HBO-v } & 15 \\ \text { HBO-mgz } & 14 \\ \text { Totaal HBO } & 19\end{array}$

Bron: RUBS 1992, HBO-Monitor 1992, ROA

\section{Ontwikkeling bruto personeelsverloop}

Met name in perioden van krapte op de arbeidsmarkt is een beheersing van het personeelsverloop voor de zorginstellingen van groot belang. Immers, voor ieder personeelslid dat vertrekt uit de instelling moet op de - dan al krappe - arbeidsmarkt weer een nieuwe beroepskracht worden 
geworven. Meer in het algemeen is de ontwikkeling van het personeelsverloop, evenals de hiervoor beschreven potentiele baanmobiliteit ook een indicatie van de mate waarin de werkenden in een instelling tevreden zijn met hun werksituatie.

Figuur 2.2. Bruto personeelsverloop in de intramurale gezondheidszorg per deelsector $1985-1991^{\mathrm{a}}$

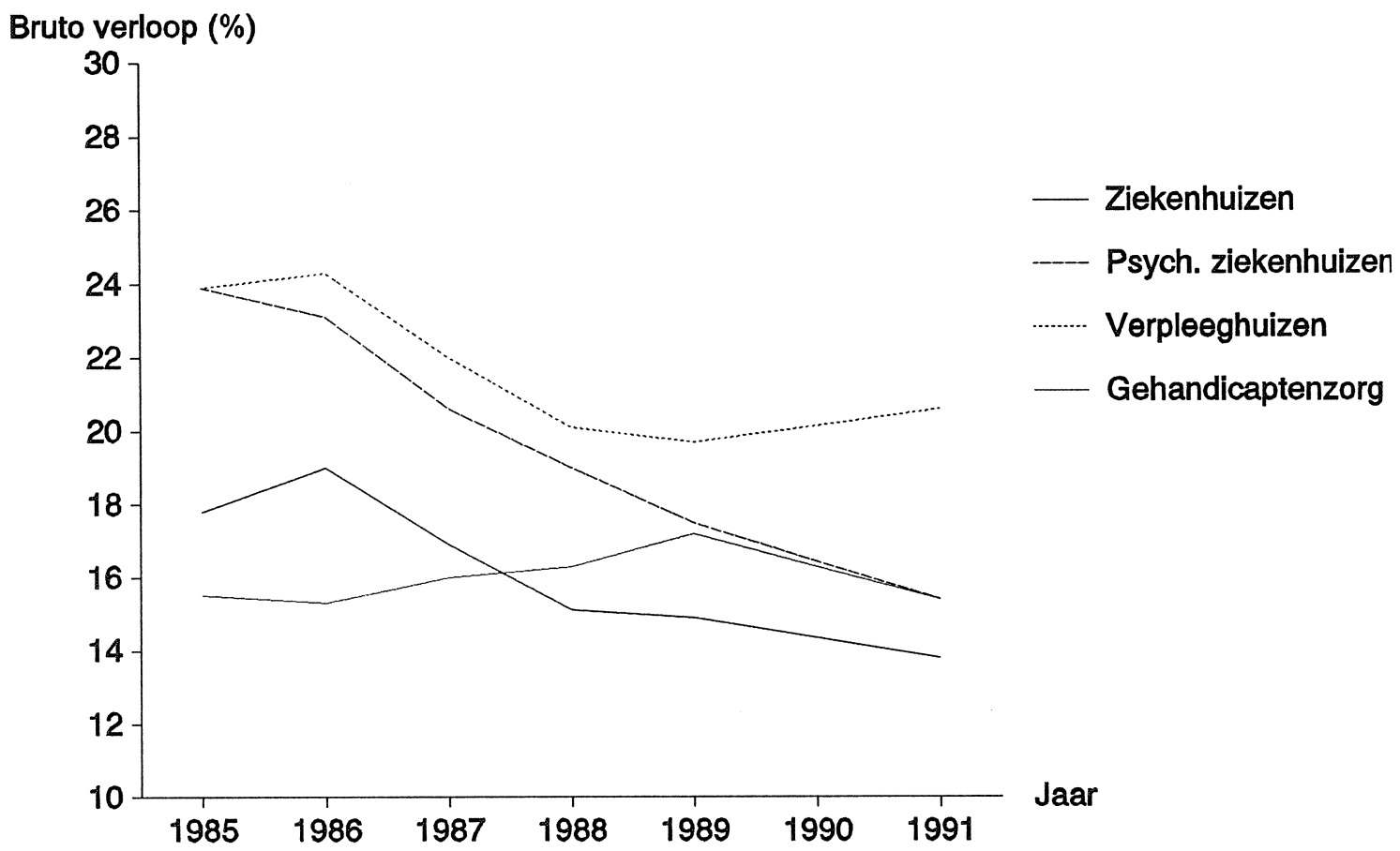

a De verloopcijfers voor 1990 ontbreken. Deze zijn daarom geïnterpoleerd.

Bron: NZi, ROA

In figuur 2.2 is voor de deelsectoren in de intramurale gezondheidszorg het bruto verlooppercentage voor verpleegkundigen en ziekenverzorgenden weergegeven voor de periode 19851991. Het gaat hier om het percentage van de werkenden dat in het desbetreffende jaar een bepaalde zorginstelling heeft verlaten. Personeel kan om verschillende redenen (tijdelijk) uit de organisatie zijn vertrokken: al dan niet vergelijkbare baan in andere instelling geaccepteerd, aflopen contract, (onvrijwillig) ontslag, uittrede uit de arbeidsmarkt in verband met geboorte kind, pensionering, vervroegde uittreding/arbeidsongeschiktheid e.d.

De figuur laat zien dat het verlooppercentage in de meeste deelsectoren in de intramurale gezondheidszorg (schoksgewijs) afneemt. In de gehandicaptenzorg is het personeelsverloop pas begin jaren negentig gedaald, terwijl het percentage in de verpleeghuizen sinds 1989 weer enigszins is toegenomen. In 1991 is het personeelsverloop het grootst in de verpleeghuizen en het laagst in de ziekenhuizen. De daling van het verloop vormt enerzijds een duidelijke indicatie van de bijdrage die het lagere personeelsverloop levert aan het verminderen van de spanningen op de arbeidsmarkt. Anderzijds geeft het ook een indicatie van het afnemen van de spanningen 
op de arbeidsmarkt zelf.

Pool, Meeuwsen, Michels en Van der Windt (1992) geven aan dat er een samenhang bestaat tussen de omvang van het aantal moeilijk vervulbare vacatures, het ziekteverzuim en het personeelsverloop. In organisaties waar het werkklimaat niet goed is, is het ziekteverzuim en het personeelsverloop hoog en is het vaak moeilijk om aan nieuw personeel te komen. Het moeilijk kunnen vervullen van de opengevallen plaatsen, versterkt de werkdruk op het blijvende personeel, zodat het ziekteverzuim en het verloop verder toeneemt etc.

Tabel 2.12. Bruto personeelsverloop van verpleegkundigen en ziekenverzorgenden in de intramurale gezondheidszorg naar deelsector, geslacht en leeftijdsklasse 1987 en 1992

\begin{tabular}{|c|c|c|c|c|c|c|c|c|}
\hline \multirow[t]{2}{*}{$\begin{array}{l}\text { Geslacht en } \\
\text { leeftijd }\end{array}$} & \multicolumn{2}{|c|}{ Ziekenhuizen } & \multicolumn{2}{|c|}{$\begin{array}{l}\text { Psychiatrische } \\
\text { Ziekenhuizen }\end{array}$} & \multicolumn{2}{|c|}{ Verpleeghuizen } & \multicolumn{2}{|c|}{$\begin{array}{c}\text { Gehandicapten- } \\
\text { zorg }\end{array}$} \\
\hline & $\begin{array}{r}1987 \\
\%\end{array}$ & $\begin{array}{r}1992 \\
\%\end{array}$ & $\begin{array}{r}1987 \\
\%\end{array}$ & $\begin{array}{r}1992 \\
\%\end{array}$ & $\begin{array}{r}1987 \\
\%\end{array}$ & $\begin{array}{r}1992 \\
\%\end{array}$ & $\begin{array}{r}1987 \\
\%\end{array}$ & $\begin{array}{r}1992 \\
\%\end{array}$ \\
\hline \multicolumn{9}{|l|}{ Vrouwen } \\
\hline$<25$ jaar & 22 & 16 & 37 & 34 & 28 & 29 & 32 & 31 \\
\hline 25-34 jaar & 19 & 13 & 21 & 17 & 21 & 17 & 19 & 14 \\
\hline $35-44$ jaar & 11 & 8 & 13 & 10 & 18 & 13 & 16 & 10 \\
\hline 45-54 jaar & 8 & 7 & 12 & 7 & 15 & 12 & 19 & 9 \\
\hline 55-64 jaar & 18 & 15 & 20 & 14 & 21 & 18 & 19 & 14 \\
\hline \multicolumn{9}{|l|}{ Mannen } \\
\hline$<25$ jaar & 29 & 26 & 57 & 49 & 44 & 45 & 39 & 43 \\
\hline 25-34 jaar & 15 & 14 & 18 & 16 & 23 & 23 & 18 & 17 \\
\hline 35-44 jaar & 8 & 8 & 10 & 9 & 19 & 14 & 10 & 8 \\
\hline 45-54 jaar & 10 & 5 & 5 & 4 & 14 & 14 & 6 & 8 \\
\hline 55-64 jaar & 28 & 20 & 19 & 12 & 36 & 3 & 21 & 17 \\
\hline
\end{tabular}

Bron: NZi/ROA

Voor de deelsectoren in de intramurale gezondheidszorg zijn ook gegevens beschikbaar over het verschil in ontwikkeling van het bruto personeelsverloop van verpleegkundigen en ziekenverzorgenden tussen mannen en vrouwen en tussen verschillende leeftijdscategorieën. In tabel 2.12 zijn de gegevens over de jaren 1987 en 1992 opgenomen. Het blijkt dat er zowel tussen mannen en vrouwen als tussen de diverse leeftijdscategorieën enige verschillen in personeelsverloop bestaan. Met name in de leeftijdscategorie tot 25 jaar is het verloop bijzonder hoog. Het 'job-hoppen' onder jongeren kan enerzijds onvrijwillig zijn door de afloop van tijdelijke contracten. Anderzijds kan dit het gevolg zijn van het zoeken naar een voor hen passende baan. Vooral onder de mannen is er sprake van een hoog verloop in de jongste leeftijdscategorie. Wellicht speelt hier mee dat mannen in deze door vrouwen gedomineerde beroepscategorie moeite hebben om een baan en team te vinden welk(e) aan hun wensen voldoet. Omgekeerd zijn vrouwen vaak eerder tevreden met de baan die ze hebben. In de daarop volgende leeftijdsklassen neemt het verlooppercentage sterk af. Bij de mannen is deze afname overigens groter dan bij de vrouwen. Hoewel deze bruto verlooppercentages geen uitsluitsel geven over de reden van het verloop (vertrek naar andere zorginstellingen, volledige terugtreding van de arbeidsmarkt) mag worden aangenomen dat het enigszins hogere verloop onder vrouwen in de 
middelste leeftijdsklassen voor een belangrijk deel veroorzaakt wordt door uittrede vanwege de verzorging van de eigen kinderen. Onder de $55^{+}$-ers is het bruto personeelsverloop relatief hoog hetgeen vanzelfsprekend met name samenhangt met de (vervroegde) pensionering of arbeidsongeschiktheid van de werkenden.

Zoals blijkt uit tabel 2.13, ligt het bruto personeelsverloop in de gezinszorg eind jaren tachtig tussen de $13 \%$ en $14 \%$. Daarbij is het verschil tussen de helpenden en verzorgenden gering. Uit aanvullende gegevens van de Landelijke Vereniging voor Thuiszorg (LVT) blijkt dat bij de helpenden het instroompercentage in beide jaren lager is dan het uitstroompercentage. Dit betekent dat de opengevallen plaatsen niet zijn opgevuld. Enerzijds kan dit het gevolg zijn van een afnemende werkgelegenheid voor helpenden in de gezinszorg. Anderzijds is het ook mogelijk dat de instellingen onvoldoende helpenden hebben kunnen werven. Voor de sector kruiswerk zijn vrijwel geen recente gegevens over het bruto verloop bekend. In de bejaardenzorg loopt het verlooppercentage uiteen van $9,2 \%$ voor de verpleegkundigen tot $16,7 \%$ voor de ziekenverzorgenden (zie tabel 2.14).

Tabel 2.13. Bruto personeelsverloop in de gezinszorg naar beroepsgroep, 1988 en 1989

\begin{tabular}{lcc}
\hline Beroepsgroep & \multicolumn{3}{c}{ Bruto personeelsverloop } \\
& $\begin{array}{c}1988 \\
\%\end{array}$ & $\begin{array}{c}1989 \\
\%\end{array}$ \\
\hline Verzorgenden & & 14,0 \\
Helpenden & 14,2 & 13,7 \\
\hline
\end{tabular}

Bron: LVT

Tabel 2.14. Bruto personeelsverloop in de bejaardenoorden naar beroepsgroep in de periode half mei 1990 tot half mei 1991

Beroepsgroep

Verpleegkundigen

Ziekenverzorgenden

Verzorgenden

Helpenden
Bruto personeelsverloop

$\%$

Bron: AWOB-enquête

Beeldvorming en keuze-intentie ten aanzien van werk in de gezondheidszorg

In het voorafgaande zijn indicatoren besproken die meer inzicht verschaffen in eventuele actuele knelpunten in de zorgsector. Tot slot van deze paragraaf zullen enkele indicatoren worden gepresenteerd die betrekking hebben op de beeldvorming en de keuze-intentie onder jongeren voor wat betreft het werken en leren in de gezondheidszorg. Indien het imago van de 
gezondheidszorg onder jongeren sterk afwijkt van de feitelijke situatie in de gezondheidszorg, is het zaak de jongeren beter te informeren. Is het imago niet goed en komt dit overeen met de feitelijke situatie, dan zullen uiteraard de knelpunten zelf aangepakt dienen te worden. De gegevens zijn ontleend aan een door het ROA gehouden schriftelijke enquête onder ruim 2.000 leerlingen van het voortgezet onderwijs ${ }^{8}$.

In de enquête konden de VBO- en MAVO-leerlingen kenbaar maken met welke van de vier vervolgopleidingen, het middelbaar agrarisch onderwijs (MAO), het middelbaar technisch onderwijs (MTS), het middelbaar economisch-administratief onderwijs (MEAO) en het middelbaar dienstverlenend en gezondheidszorgonderwijs (MDGO), men de grootste kans op werk verwacht. De HAVO-leerlingen konden kiezen uit zes vervolgopleidingen, te weten: het hoger pedagogisch onderwijs, het hoger agrarisch onderwijs, het hoger technisch onderwijs, het hoger economisch onderwijs, het hoger sociaal-cultureel onderwijs en het hoger gezondheidszorgonderwijs. Tevens konden de leerlingen aangeven met welke opleiding men de grootste kans denkt te hebben een hoog inkomen te verdienen. In tabel 2.15 is aangegeven welk deel van de leerlingen de kans op werk, respectievelijk de kans op een hoog inkomen voor het (dienstverlenend en) gezondheidszorgonderwijs relatief hoog inschat, in de zin dat de leerlingen deze opleidingen op de desbetreffende punten tot de betere helft rekenen. Daarbij is tevens een onderscheid gemaakt tussen de leerlingen die opteren voor een medische of verzorgende baan of vervolgopleiding en degenen met een andere studie- en beroepskeuzevoorkeur.

Tabel 2.15. Inschatting van de kans op werk en de kans op een hoog inkomen voor schoolverlaters van het gezondheidszorgonderwijs door VBO-, MAVO- en HAVO-leerlingen die kiezen voor een medisch/verzorgende vervolgopleiding en leerlingen die een andere keuze maken

$\begin{array}{llll}\text { Huidige opleiding } & \text { VBO HAVO }\end{array}$

\begin{tabular}{|c|c|c|c|c|c|c|}
\hline & \multicolumn{2}{|c|}{ Voorkeur } & \multicolumn{2}{|c|}{ Voorkeur } & \multicolumn{2}{|c|}{ Voorkeur } \\
\hline & $\begin{array}{c}\text { Medisch/ } \\
\text { Verzorgend } \\
\%\end{array}$ & $\begin{array}{c}\text { Anders } \\
\%\end{array}$ & $\begin{array}{c}\text { Medisch/ } \\
\text { Verzorgend } \\
\%\end{array}$ & $\begin{array}{c}\text { Anders } \\
\qquad \%\end{array}$ & $\begin{array}{c}\text { Medisch/ } \\
\text { Verzorgend } \\
\%\end{array}$ & $\begin{array}{r}\text { Anders } \\
\%\end{array}$ \\
\hline $\begin{array}{l}\text { Relatief grote kans op } \\
\text { werk }\end{array}$ & 83 & 43 & 74 & 52 & 72 & 51 \\
\hline $\begin{array}{l}\text { Relatief grote kans op } \\
\text { een hoog inkomen }\end{array}$ & 56 & 31 & 49 & 34 & 78 & 71 \\
\hline
\end{tabular}

Bron: ROA

Uit de tabel blijkt dat leerlingen die een toekomst in de gezondheidszorg ambiëren voor het overgrote deel verwachten dat de kans op werk in deze sector relatief groot is. De andere

8. De meting heeft in het derde leerjaar van het MAVO en voorbereidend beroepsonderwijs (VBO) plaatsgevonden en in het vierde leerjaar van het HAVO. Het gaat derhalve om jongeren van zo'n 14 à 15 jaar (zie voor een verdere toelichting Willems en De Grip, 1993). 
leerlingen zijn veel minder vaak optimistisch over de kans op werk voor schoolverlaters van medische of verzorgende vervolgopleidingen. De VBO- en MAVO-leerlingen die belangstelling hebben voor de zorgsector verwachten bovendien dat degenen met een gezondheidszorgopleiding vaker een relatief hoog inkomen verdienen. Bij het HAVO, waar het percentage leerlingen met een relatief hoge inkomensverwachting voor de zorgsector hoog is, zijn de verschillen tussen degenen die wel en degenen die geen belangstelling voor de zorgsector hebben gering.

Om na te gaan welk type leerlingen voor een medisch/verzorgende opleiding kiezen, is onderzocht in hoeverre toekomstige werkmotieven van invloed zijn op de keuze van de vervolgopleiding. De leerlingen hebben in de enquête aangeven wat zij het belangrijkste vinden voor hun toekomst: omgaan met mensen, carrière maken of nuttig werk doen. De percentages in tabel 2.16 geven aan welk deel van de leerlingen de desbetreffende mogelijkheid het meest belangrijk vindt.

Tabel 2.16. Belang van bepaalde werkmotieven voor VBO-, MAVO- en HAVO-leerlingen die kiezen voor een medisch/verzorgende vervolgopleiding en leerlingen die een andere keuze maken

$\begin{array}{lll}\text { Huidige opleiding HAVO } & \text { MBO }\end{array}$

\begin{tabular}{llcccc}
\hline \multicolumn{2}{c}{$\begin{array}{c}\text { Voorkeur } \\
\text { Medisch/ } \\
\text { Verzorgend } \\
\%\end{array}$} & $\%$ & $\begin{array}{c}\text { Voorkeur } \\
\text { Medisch/ } \\
\text { Verzorgend } \\
\%\end{array}$ & $\begin{array}{c}\text { Voorkeur } \\
\text { Medisch/ Anders } \\
\text { Verzorgend } \\
\%\end{array}$ & $\begin{array}{c}\text { Anders } \\
\%\end{array}$ \\
\hline
\end{tabular}

Belangrijkste voor eigen toekomst

$\begin{array}{lllllll}\text { omgaan met mensen } & 58 & 20 & 61 & 32 & 71 & 41 \\ \text { carrière maken } & 21 & 41 & 19 & 41 & 17 & 38 \\ \text { nuttig werk doen } & 21 & 39 & 20 & 27 & 12 & 21\end{array}$

Bron: ROA

De tabel laat zien dat de leerlingen die graag verder willen in de zorgsector dit niet doen uit carrière-overwegingen. Integendeel, het grootste deel onder hen vindt het omgaan met mensen het belangrijkste. Bij de leerlingen die geen opleiding en baan in de zorgsector ambiëren zijn het maken van carrière of het doen van nuttig werk (naar verhouding) veel vaker het belangrijkste van deze drie toekomstige baanmotieven.

Daarnaast is het relatieve imago van het werken in de gezondheidszorg van belang. Daarbij is in de enquête een onderscheid gemaakt tussen vijf verschillende kwalitatieve aspecten van het werk:

- werk dat lichamelijk zwaar is;

- werk dat veel stress met zich meebrengt;

- werk waarbij je vuil werk moet doen;

- werk waarbij je saai werk moet doen; 
- werk waarbij je veel dingen zelfstandig kunt regelen.

Indien bijvoorbeeld de leerlingen aangeven dat de kans op saai werk met een gezondheidszorgopleiding het grootst is, moet dat worden geïnterpreteerd als een relatief grote kans op saai werk in vergelijking met de andere opleidingsrichtingen. Daarbij zal ook telkens worden aangegeven welke opleidingsrichting op het desbetreffende punt het meest concurrerend is.

Tabel 2.17 schetst een beeld van het imago van de kwalitatieve aspecten van het werk in de gezondheidszorg. Het is opmerkelijk dat met name de leerlingen die belangstelling hebben voor de gezondheidszorg verwachten dat dit beroep lichamelijk zwaar is. De leerlingen die niet opteren voor een medische of verzorgende baan of vervolgopleiding verwachten overigens ook redelijk vaak dat het werken in de gezondheidszorg relatief zwaar is. De grootste concurrentie gaat hier uit van het economisch-administratieve onderwijs. Leerlingen verwachten in het algemeen dat beroepen die aansluiten op een MEAO- en HEAO-opleiding lichamelijk het minst zwaar zullen zijn.

Tabel 2.17. Inschatting van de kans op bepaalde kwalitatieve aspecten van het werk voor schoolverlaters van het gezondheidszorgonderwijs door VBO-, MAVO- en HAVO-leerlingen die kiezen voor een medisch/verzorgende vervolgopleiding en leerlingen die een andere keuze maken

\begin{tabular}{|c|c|c|c|c|c|c|}
\hline \multirow[t]{2}{*}{ Huidige opleiding } & \multicolumn{2}{|c|}{ VBO } & \multicolumn{2}{|c|}{ MAVO } & \multicolumn{2}{|c|}{ HAVO } \\
\hline & $\begin{array}{c}\text { Voorkeu } \\
\text { Medisch/ } \\
\text { Verzorgend } \\
\%\end{array}$ & $\begin{array}{r}\text { Anders } \\
\%\end{array}$ & $\begin{array}{l}\text { Voorkel } \\
\text { Medisch/ } \\
\text { Verzorgend } \\
\%\end{array}$ & $\begin{array}{c}\text { Anders } \\
\%\end{array}$ & $\begin{array}{l}\text { Voorkeu } \\
\text { Medisch/ } \\
\text { Verzorgend } \\
\%\end{array}$ & $\begin{array}{r}\text { Anders } \\
\%\end{array}$ \\
\hline $\begin{array}{l}\text { Relatief grote kans } \\
\text { op zwaar werk }\end{array}$ & 72 & 41 & 61 & 53 & 83 & 62 \\
\hline $\begin{array}{l}\text { Relatief grote kans } \\
\text { op veel stress }\end{array}$ & 63 & 74 & 75 & 74 & 22 & 44 \\
\hline $\begin{array}{l}\text { Relatief grote kans } \\
\text { op vuil werk }\end{array}$ & 41 & 37 & 46 & 50 & 61 & 63 \\
\hline $\begin{array}{l}\text { Relatief grote kans } \\
\text { op saai werk }\end{array}$ & 14 & 58 & 15 & 45 & 4 & 35 \\
\hline $\begin{array}{l}\text { Relatief grote kans } \\
\text { op zelfstandig werk }\end{array}$ & 65 & 30 & 45 & 29 & 39 & 47 \\
\hline
\end{tabular}

Bron: ROA

Vooral de VBO- en MAVO-leerlingen verwachten relatief vaak een hoge mate van stress bij het werk in de gezondheidszorg. De leerlingen van het HAVO, vooral degenen die belangstelling hebben voor de gezondheidszorg, denken beduidend minder vaak dat het werken in de gezondheidszorg veel stress met zich meebrengt. VBO- en MAVO-leerlingen verwachten dat het 
economisch-administratief en het gezondheidszorgonderwijs de grootste kans heeft voor een beroep met veel stress. Zij verwachten daarentegen de minste stress bij beroepen waarvoor het agrarisch onderwijs opleidt. HAVO-leerlingen zijn van mening dat het hoger pedagogisch onderwijs relatief de grootste kans op een baan met veel stress oplevert. Deze kans is volgens de HAVO-leerlingen het kleinst bij de hoger agrarische, technische en gezondheidszorgopleidingen.

Met name de HAVO-leerlingen verwachten vaak dat bij een keuze voor een gezondheidszorgopleiding de kans op vuil werk verhoudingsgewijs groot is. Daarbij bestaan er slechts kleine verschillen tussen leerlingen die belangstelling hebben voor de gezondheidszorg en leerlingen die een andere studie- en beroepskeuze willen maken. Volgens de leerlingen heeft men met een agrarische opleiding de grootste kans op een baan waarbij je vuil werk moet doen. Een economisch-administratieve opleiding levert hierop de kleinste kans.

Slechts een klein deel van de leerlingen die van plan zijn om in de toekomst in de gezondheidszorg te gaan werken, verwacht dat een gezondheidszorgopleiding straks vaak saai werk zal opleveren. Leerlingen die geen belangstelling hebben voor een baan in de gezondheidszorg, achten de kans hierop veel groter. Men verwacht overigens het vaakst dat een economisch-administratieve opleiding saai werk oplevert. Voor de rest zijn er weinig verschillen tussen de opleidingsrichtingen op dit punt te constateren.

Alleen de VBO-leerlingen die opteren voor een baan of vervolgopleiding in de gezondheidszorg, verwachten vaak dat men bij een baan in de gezondheidszorg veel zelf kan regelen. Bij de MAVO- en HAVO-leerlingen is dit percentage aanzienlijk lager. Op het punt van zelfstandigheid blijkt het imago van beroepen waarvoor het agrarisch onderwijs opleidt het beste te zijn. VBOen MAVO-leerlingen achten al met al de kans op een baan met veel zelfstandigheid het kleinst bij een keuze voor het MDGO, terwijl de HAVO-leerlingen de relatief kleinste kans toedichten aan degenen die een hoger pedagogische opleiding hebben afgerond.

Door Dorenbos (1994) is nagegaan welke factoren het belangrijkste zijn voor de keuze van leerlingen voor de medisch/verzorgende richting. In deze analyse zijn zowel persoonskenmerken, omgevingskenmerken, als de verschillende aspecten van het imago van het werk in de zorgsector meegenomen. Het blijkt dat voor zowel VBO-, als MAVO- en HAVO- leerlingen het geslacht een significant verklarende factor is bij de keuze om al dan niet verder te gaan in de gezondheidszorg: meisjes hebben een grotere belangstelling voor de gezondheidszorg. De (leer)capaciteiten spelen daarbij geen significante rol. In het algemeen is het opleidingsniveau van de ouders ook niet van invloed op de keuze voor de gezondheidszorg. De leerlingen waarvan de vader een medisch/verzorgend beroep heeft, blijken significant vaker belangstelling te hebben voor het werken in de gezondheidszorg.

Verder zijn VBO- en MAVO- leerlingen die carrière maken het belangrijkste vinden in de toekomst significant minder in een toekomst in de gezondheidszorg geïnteresseerd dan leerlingen die het omgaan met mensen het belangrijkste vinden. Dit geldt ook voor VBOleerlingen die nuttig werk willen doen als belangrijkste arbeidsmotief zien. 
Op bepaalde punten blijkt het imago van invloed te zijn om al dan niet te kiezen voor een toekomst in de gezondheidszorg. Dit geldt met name voor de VBO-leerlingen. VBO-leerlingen die voor de gezondheidszorg een grote kans op werk, een kleine kans op stress en saai werk en een grote kans op het zelfstandig uitoefenen van het (medisch/verzorgend) beroep verwachten, kiezen vaker voor een baan of vervolgopleiding in de gezondheidszorg. Bij de MAVO- en HAVOleerlingen bepaalt met name de verwachting ten aanzien van het wel of niet saai zijn van een beroep in een bepaalde sector of men kiest voor de gezondheidszorg of niet. Overigens mag worden aangenomen dat dit deels samenhangt met het belangrijkste motief dat leerlingen voor ogen hebben bij hun studie- en beroepskeuze.

\subsection{Werkgelegenheid}

\section{Ontwikkeling personeelsomvang}

Om een indruk te krijgen in de achterliggende dynamiek van de ontwikkeling van de knelpunten op de arbeidsmarkt in de zorgsector, is het nuttig een blik te werpen op de ontwikkeling van de werkgelegenheid in de verschillende deelsectoren. Figuur 2.3 geeft voor de afzonderlijke deelsectoren in de zorgsector de werkgelegenheidsontwikkeling weer in de periode 1985-1991, uitgesplitst naar de onderscheiden beroepsgroepen. De werkgelegenheidsontwikkeling biedt inzicht in de groei of krimp van de werkgelegenheid voor bepaalde beroepscategorieën of deelsectoren.

Om een goed beeld te geven van de verschuivingen in de werkgelegenheid hebben de cijfers betrekking op het aantal bezette arbeidsplaatsen uitgedrukt in zogenaamde full time equivalents (f.t.e.'s). De aantallen verpleegkundigen, ziekenverzorgenden, verzorgenden en helpenden zijn cumulatief weergegeven, waarbij het laagste deskundigheidsniveau ${ }^{9}$ onderaan is geplaatst. Zo is in één oogopslag de ontwikkeling van de totale werkgelegenheid voor de relevante beroepsgroepen in een deelsector duidelijk.

Uit de figuur blijkt dat de werkgelegenheid in de verpleegkundige en verzorgende beroepen tussen 1985 en 1991 licht is toegenomen. Bij de gehandicaptenzorg en de bejaardenoorden is zelfs sprake van een forse toename. Ook bij de psychiatrische ziekenhuizen en de verpleeghuizen is de werkgelegenheidsgroei relatief groot. Bij de meeste deelsectoren is de toename halverwege de jaren tachtig overigens sterker dan in de jaren daarna. De gezinszorg en de gehandicaptenzorg vormen hierop een uitzondering. Bij de gezinszorg neemt de werkgelegenheid na 1985 eerst licht af om vervolgens eind jaren tachtig toe te nemen.

Met uitzondering van de verpleeghuizen is het percentage ziekenverzorgenden in de intramurale gezondheidszorg laag. De werkgelegenheidsgroei is bovendien voornamelijk ten goede gekomen aan de verpleegkundigen. In de verpleeghuizen bestaat het grootste gedeelte van de uitvoerende

9. Hierbij moet worden bedacht, dat het de deskundigheidsniveaus betreft die in dit onderzoek zijn betrokken. De (toenemende) groep verpleeghulpen zijn in dit onderzoek buiten beschouwing gelaten. 
beroepskrachten uit ziekenverzorgenden. De relatief grote werkgelegenheidsgroei in deze sector is bij de ziekenverzorgenden overigens sterker geweest dan bij de verpleegkundigen.

In de gezinszorg heeft de werkgelegenheidsgroei de afgelopen jaren met name betrekking gehad op de verzorgenden. Desalniettemin blijft het aandeel van de helpenden in deze sector het grootst. Binnen de sector kruiswerk is de werkgelegenheid van verzorgenden de afgelopen jaren ongeveer gelijk gebleven. Dit betreft de kraamverzorgenden in de kraamcentra. In de andere kruiswerkinstellingen (wijkverpleging) zijn voornamelijk verpleegkundigen werkzaam, alhoewel het aandeel van de ziekenverzorgenden de laatste jaren iets toeneemt. Bij de bejaardenoorden is het aantal verpleegkundigen de afgelopen jaren vrij constant. Daarentegen is het aantal ziekenverzorgenden gestegen. De werkgelegenheid voor verzorgenden is eerst afgenomen, maar neemt de laatste jaren weer (sterk) toe. Het aandeel helpenden is in de periode 1985-1991 min of meer gelijk gebleven.

Figuur 2.3. Werkgelegenheidsontwikkeling (arbeidsvolume) naar deelsector en beroepsgroep 1985-1991
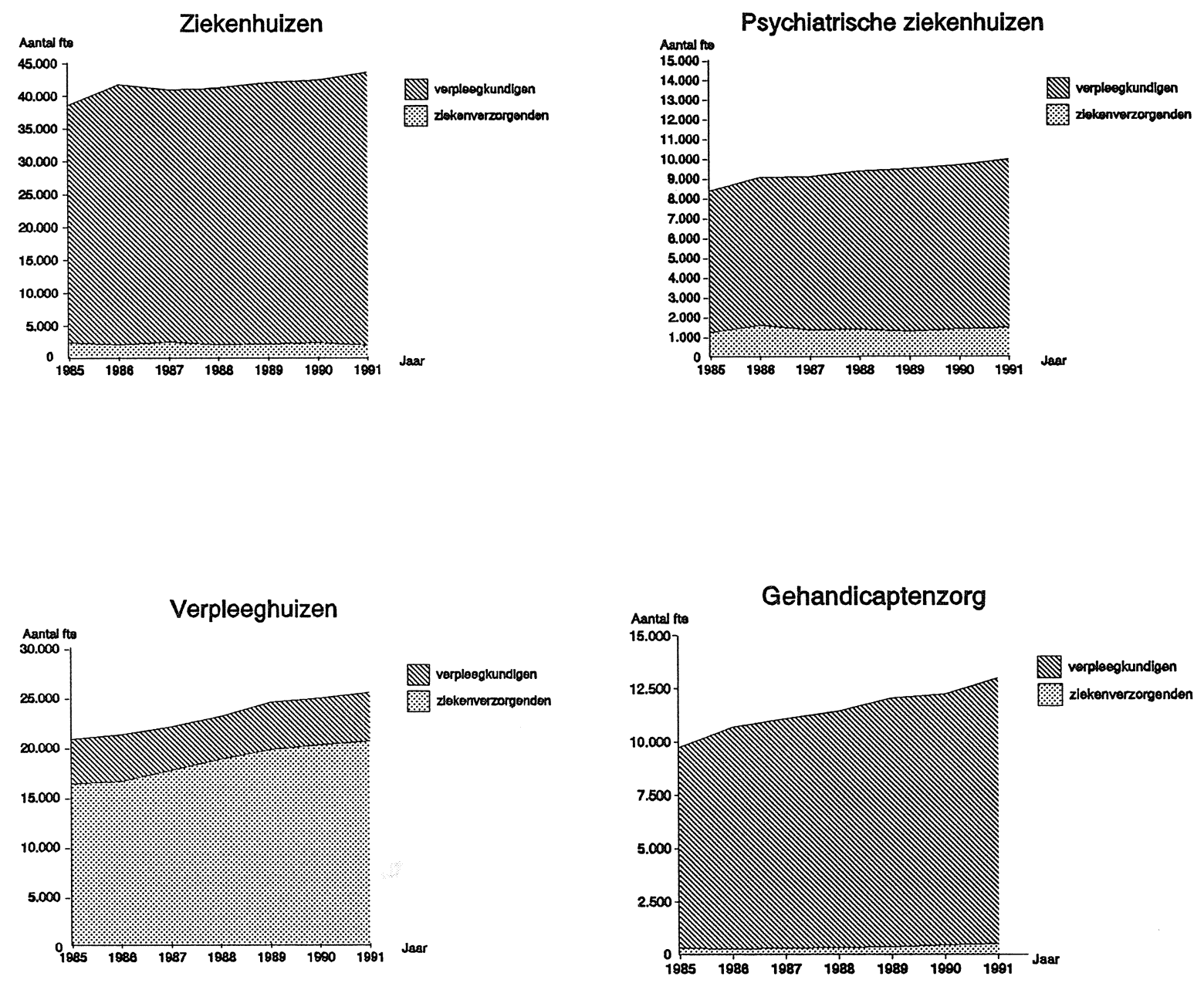
Figuur 2.3. Werkgelegenheidsontwikkeling (arbeidsvolume) naar deelsector en beroepsgroep 1985-1991 (vervolg)
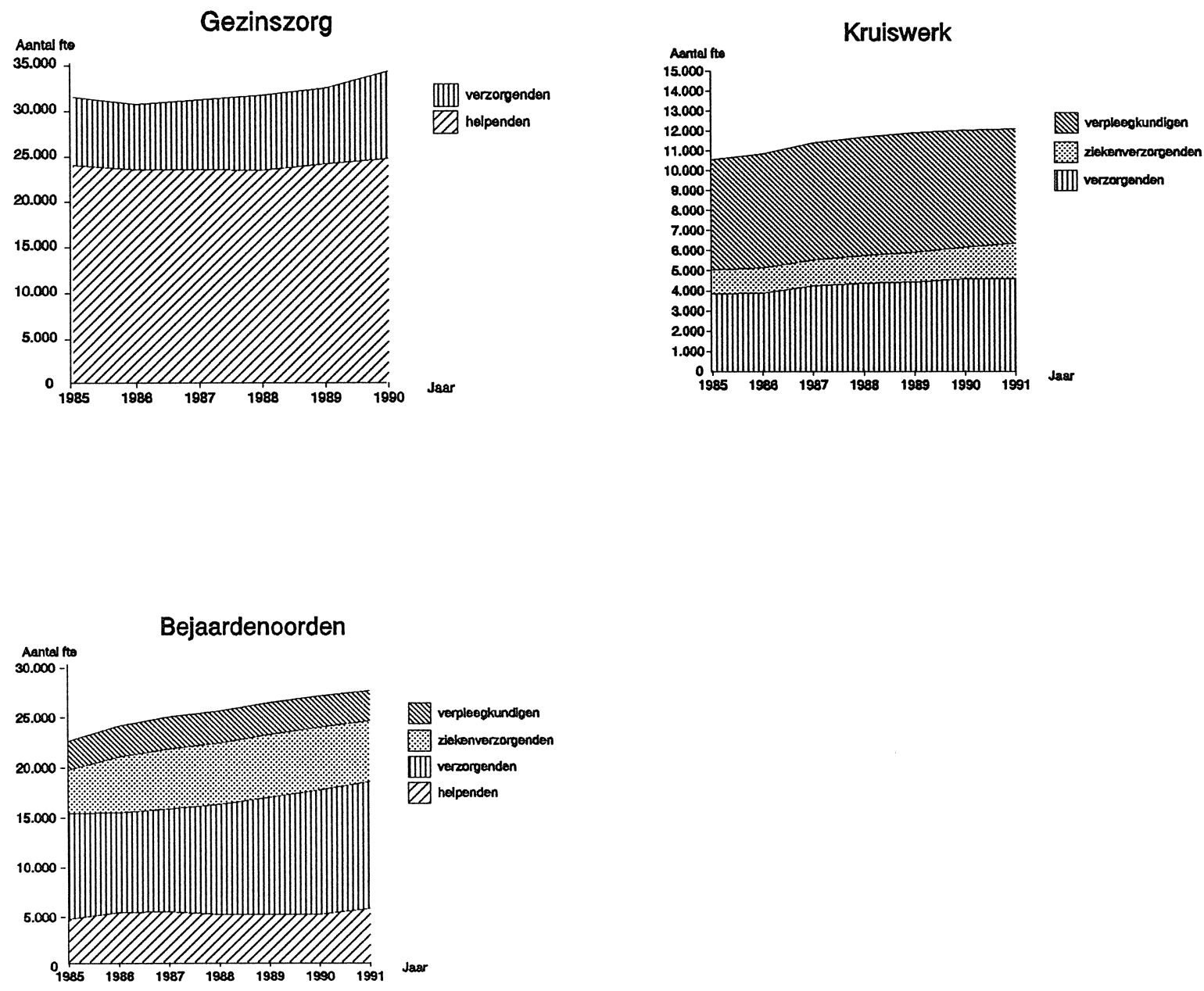

a Voor de gezinszorg zijn geen werkgelegenheidsgegevens voorhanden voor het jaar 1987. De aantallen voor 1987 zijn daarom geschat door uit te gaan van de gemiddelden over de jaren 1986 en 1988.

Bron: NZi, LVT, CBS, ROA

\section{Ontwikkeling deeltijdarbeid}

Aangezien in de zorgsector met name veel vrouwen werkzaam zijn in een deeltijdfunctie, is een overzicht van de werkgelegenheidsontwikkeling pas compleet wanneer ook wordt ingegaan op de ontwikkeling van het percentage verpleegkundigen en verzorgenden dat een deeltijdaanstelling heeft. Immers, wanneer het percentage deeltijders bij een gelijkblijvend arbeidsvolume (f.t.e.'s) stijgt, neemt de werkgelegenheid uitgedrukt in werkzame personen toe.

Figuur 2.4 laat zien dat het aantal deeltijdwerkers in de intramurale gezondheidszorg de afgelopen jaren sterk is toegenomen. In 1985 blijkt circa $40 \%$ van het totale verpleegkundige en 
verzorgende personeel een deeltijdbaan te hebben. Bij de verpleeghuizen is dat op dat moment al voor bijna de helft van de werkenden het geval. In alle intramurale gezondheidszorgsectoren is het percentage deeltijdwerkers nadien verder gestegen tot gemiddeld zo'n 60\% in 1991 .

Figuur 2.4. Percentage verpleegkundig en verzorgend personeel met een deeltijdaanstelling naar deelsector 1985-1991
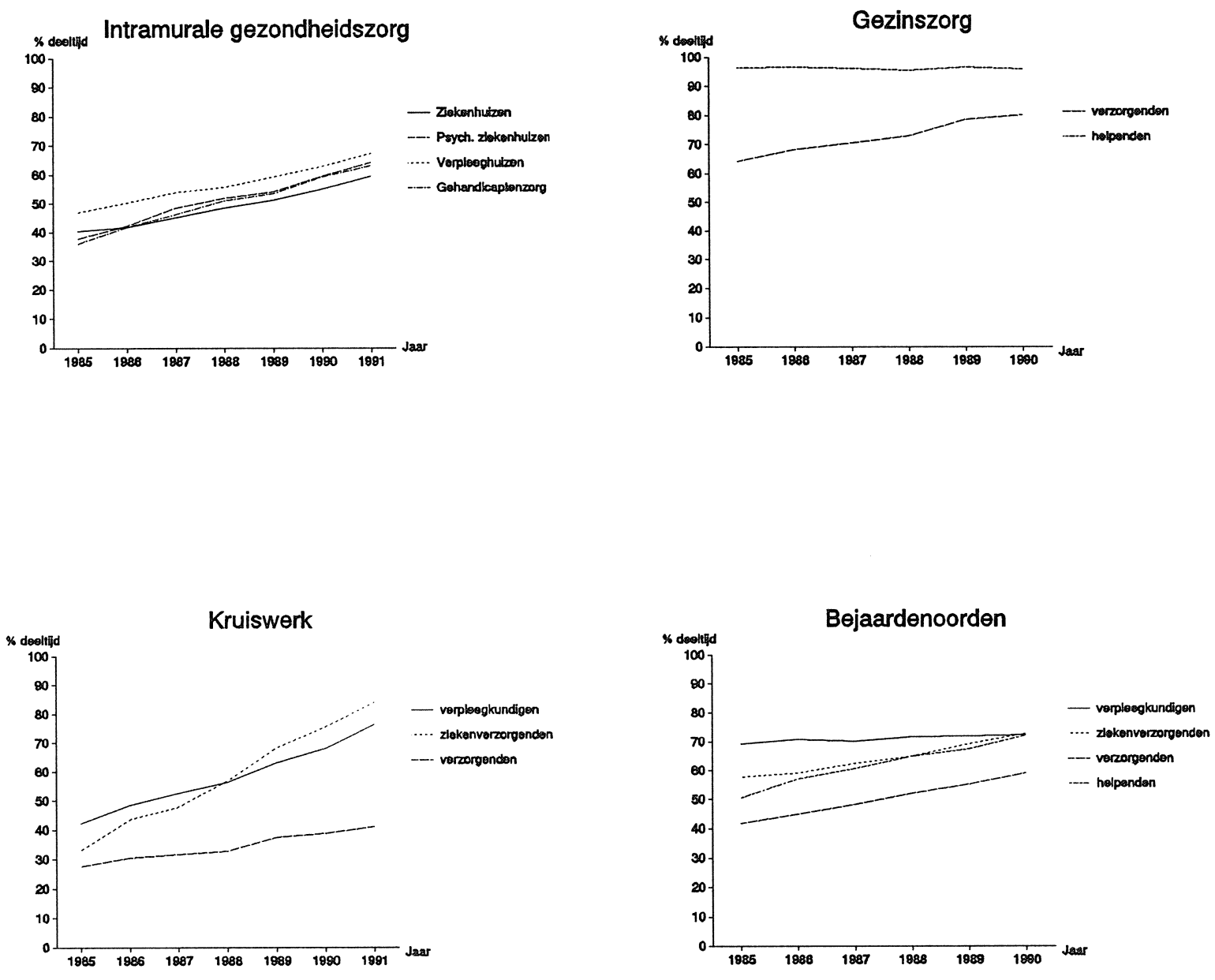

Bron: NZi, LVT, CBS, ROA

Ook in de gezinszorg, het kruiswerk en de bejaardenoorden is het percentage personeelsleden met een deeltijdaanstelling de afgelopen jaren toegenomen. Vooral in de sector kruiswerk is de toename aanzienlijk. Deze stijging doet zich vooral voor bij de verpleegkundigen en de ziekenverzorgenden. Daarentegen blijkt het percentage verzorgenden dat in deze sector een deeltijdfunctie heeft relatief laag is, ofschoon dit percentage ook voor deze beroepsgroep is toegenomen. 
De figuur laat verder zien dat de helpenden in de gezinszorg vrijwel allemaal een deeltijdfunctie bekleden. Bij de verzorgenden in deze sector is het aandeel deeltijdwerkers tussen 1985 en 1990 toegenomen van ruim $60 \%$ naar bijna $80 \%$. Ook in de bejaardenoorden werken de verzorgenden het minst vaak in een deeltijdfunctie. Het aandeel deeltijd werkenden is echter in de periode $1985-1990$ gestegen van ruim $40 \%$ naar bijna $60 \%$. Het percentage verpleegkundigen, ziekenverzorgenden en helpenden met een deeltijdaanstelling bedraagt in 1990 circa $70 \%$.

\subsection{Vervangingsvraag}

In paragraaf 2.3 zijn gegevens gepresenteerd over het bruto personeelsverloop als indicator voor arbeids(markt)knelpunten in de zorgsector. Vanuit arbeidsmarkteconomisch oogpunt is echter niet alleen het bruto verloop van belang, het netto verloop is minstens even belangrijk. Bij dit netto verloop wordt geen rekening gehouden met de intra-sector mobiliteit, dat wil zeggen de mobiliteit van werkenden van de ene instelling in een bepaalde deelsector naar een andere instelling in de desbetreffende sector. Deze baan-baan mobiliteit heeft immers alleen tot gevolg dat er een 'rondcirkeling' op de arbeidsmarkt plaatsvindt. Per saldo komen er geen vacatures voor nieuwkomers bij (zie ook De Grip, Meijboom en Willems, 1993). In deze paragraaf zal nader worden ingegaan op dit netto personeelsverloop ofwel, meer concreet, de netto vervangingsbehoefte aan schoolverlaters. Hierover zijn niet direct gegevens voorhanden, maar de vervangingsvraag kan wel worden geschat op basis van een door het ROA ontwikkelde methodiek. Daarbij is reeds rekening gehouden met de instroom van niet-schoolverlaters, zoals bijvoorbeeld herintredende vrouwen ${ }^{10}$. Dit betekent dat de werkgelegenheidsgroei, als gepresenteerd in paragraaf 2.4 en de vervangingsvraag volledig moet worden 'opgevangen' door de instroom van schoolverlaters.

Tabel 2.18 geeft een beeld van de vervangingsvraag naar schoolverlaters verbijzonderd naar deelsector in de periode 1990-1992. Het blijkt dat vooral in de verpleeghuizen relatief veel bestaande arbeidsplaatsen door schoolverlaters opnieuw zijn opgevuld. Ook in de ziekenhuizen en de psychiatrische ziekenhuizen is de vervangingsbehoefte verhoudingsgewijs groot. In de gehandicaptenzorg is er daarentegen sprake van een relatief lage vervangingsvraag naar schoolverlaters. Dit beeld stemt redelijk overeen met de verschillen tussen de sectoren in het bruto verloop (zie figuur 2.2). Ook daarbij geldt dat het verloop bij de verpleeghuizen relatief hoog is en bij de gehandicaptenzorg relatief laag.

In de gezinszorg is de vervangingsvraag naar schoolverlaters met gemiddeld 1,5\% per jaar relatief laag. Dit heeft vooral te maken met het feit dat in deze sector de instroom van nietschoolverlaters (vooral herintreders en degenen die eerst buiten deze sector een baan hadden) verhoudingsgewijs hoog is. De behoefte aan schoolverlaters is hierdoor vanzelfsprekend geringer. De vervangingsvraag naar verpleegkundigen en ziekenverzorgenden bedraagt gemiddeld ruim $3,5 \%$ per jaar.

10. Vanwege de beschikbare data kan deze instroom niet expliciet worden gemaakt. 
Tabel 2.18. Vervangingsvraag naar schoolverlaters per deelsector gemiddelde 1990-1992

Deelsector $\quad \underset{\%}{\text { Vervangingsvraag }}$

$\%$

Ziekenhuizen

Psychiatrische ziekenhuizen

Verpleeghuizen

Gehandicaptenzorg

Gezinszorg

Kruiswerk ${ }^{a}$

Bejaardenoorden ${ }^{b}$
3,9

4,2

5,2

2,9

1,5

3,7

a gemiddelde 1987-1991, exclusief verzorgenden

b geen gegevens beschikbaar

Bron: ROA

\subsection{Instroom van schoolverlaters}

De arbeidsmarktontwikkelingen zijn niet alleen afhankelijk van de werkgelegenheidsontwikkeling en de vervangingsbehoefte aan de vraagzijde van de arbeidsmarkt, maar eveneens van de ontwikkeling aan de aanbodzijde. Het gaat hier om de instroom van schoolverlaters ${ }^{11}$ op de arbeidsmarkt, uiteraard alleen voor zover zij een diploma hebben behaald van een gezondheidszorgopleiding die opleidt voor de onderscheiden beroepsgroepen. In de zorgsector is het uitoefenen van één van deze verpleegkundige of verzorgende beroepen over het algemeen aan strenge opleidingseisen gebonden. Dit maakt het mogelijk om een goed beeld te schetsen van het aanbod van verpleegkundig en verzorgend personeel in de zorgsector. Schema 2.1 geeft een overzicht van de opleidingen die gericht zijn op de verpleegkundige en verzorgende beroepen in de zorgsector.

Schema 2.1. Overzicht van beroepen en de vereiste vooropleidingen in de zorgsector

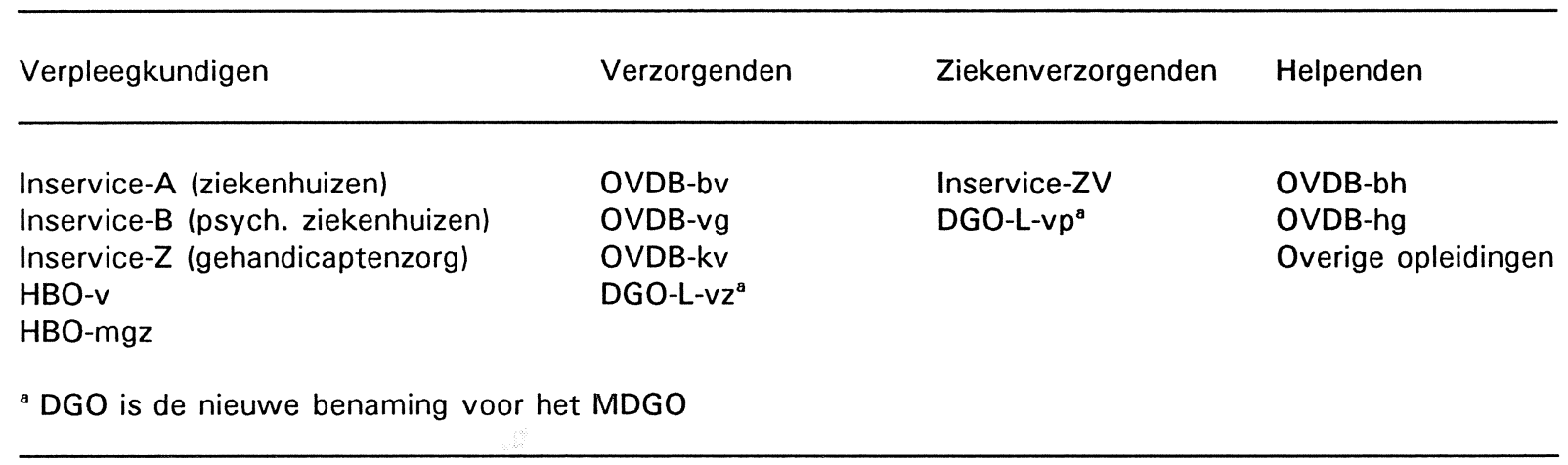

11. De instroom van herintreders en andere niet-schoolverlaters is, zoals reeds is aangegeven, verdisconteerd in de vervangingsvraag. 
Figuur 2.5. Aantal gediplomeerden van opleidingen voor verpleegkundigen, ziekenverzorgenden, verzorgenden en helpenden 1985/1986 - 1990/1991
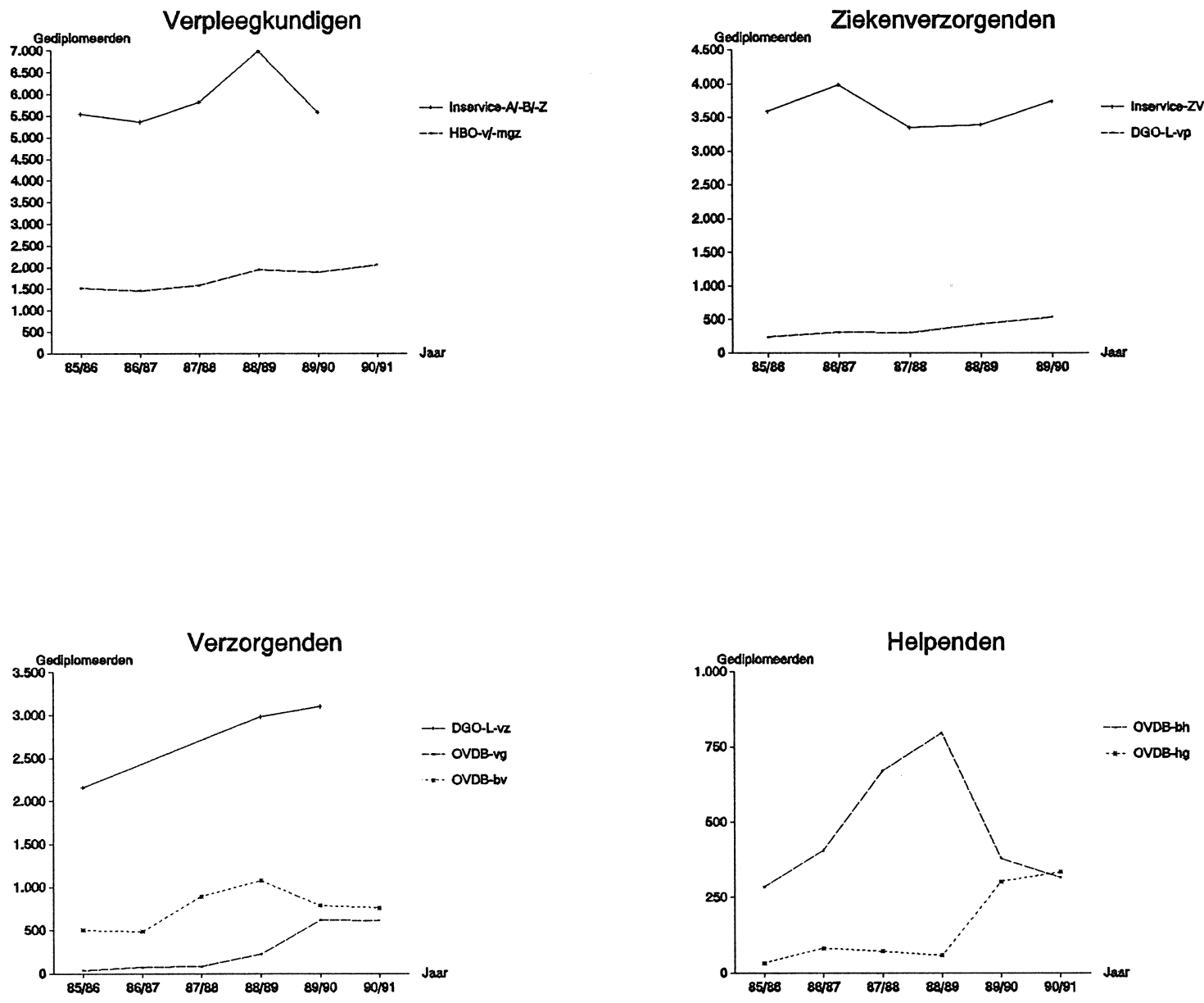

Bron: Ministerie WVC, CBS, OVDB, ROA

Figuur 2.5 geeft een overzicht van de ontwikkeling van het aantal gediplomeerden in de afgelopen jaren. De opleidingen zijn daarbij ingedeeld naar de beroepsgroep waarvoor zij opleiden. Bij de opleidingen voor verpleegkundigen is het aantal afgestudeerden van de inservice-opleidingen $A, B$ en $Z$ halverwege de jaren tachtig eerst licht gedaald, vervolgens eind jaren tachtig fors gestegen en daarna weer gedaald naar het niveau van halverwege de jaren tachtig. Het geschetste verloop illustreert de voor het imago van de zorgsector vaak fnuikende instabiliteit van de uitstroom van de inservice-opleidingen. De gediplomeerde uitstroom van verpleegkundig opgeleiden op HBO-niveau is de afgelopen jaren licht gestegen, met eveneens een iets sterkere stijging in het studiejaar 1988/1989. In het algemeen vertoont de uitstroom van deze opleidingen een veel stabieler beeld dan bij de inservice-opleidingen. Voor de verpleegkundige beroepen is de uitstroom uit het inservice-onderwijs echter veel belangrijker dan de 
uitstroom uit het $\mathrm{HBO}$-onderwijs.

Ook voor de ziekenverzorgenden is het aanbod van gediplomeerden van het inservice-onderwijs van groter belang dan het aanbod afkomstig uit het initiële dagonderwijs (DGO-L-vp). Het aantal gediplomeerden uit het DGO-L-vp is daarentegen de laatste jaren continu gegroeid. De gediplomeerde uitstroom uit de Inservice-ZV heeft echter, evenals bij de Inservice-A, -B en -Z de afgelopen jaren nogal gefluctueerd en is in 1989/1990 weer op het niveau van 1985/1986.

De gediplomeerde uitstroom uit het DGO-L-vz, die relevant is voor de beroepsgroep verzorgenden, is in de afgelopen jaren fors toegenomen. Tot het begin van de jaren negentig is het aantal gediplomeerden van de leerlingwezen-opleidingen (OVDB) gestegen. Begin jaren negentig is aan deze toename een einde gekomen.

De ontwikkelingen in het aantal gediplomeerden van opleidingen voor helpende functies in de zorgsector laat zich als volgt samenvatten ${ }^{12}$. Hoewel het aantal gediplomeerde bejaardenhelpenden (OVDB-bh) tussen 1985/1986 en 1988/1989 bijna is verdrievoudigd, bedraagt de gediplomeerde uitstroom in het studiejaar 1990/1991 nog maar ongeveer 250 personen. Het aantal gediplomeerden van de opleiding voor gezinshelpende (OVDB-hg) is sinds 1988/1989 snel toegenomen.

\section{Bestemming van schoolverlaters}

Gegevens over het aantal gediplomeerden zijn echter niet voldoende om de instroom in de zorgberoepen en/of zorgsector weer te geven. In de eerste plaats stroomt een deel van de gediplomeerden door naar een vervolgopleiding in het dagonderwijs. Een belangrijk deel hiervan zal overigens wel een vervolgstudie in dezelfde richting kiezen, zodat zij op een later tijdstip alsnog beschikbaar komen voor de arbeidsmarkt in de zorgsector, echter wel op een hoger deskundigheidsniveau. In de tweede plaats gaat een deel van de afgestudeerden naar een werkkring buiten de zorgsector. Tenslotte zal een aantal gediplomeerden zich helemaal niet aanbieden op de arbeidsmarkt. Tabel 2.19 geeft een beeld van de belangrijkste bezigheid op het moment van de enquête van de gediplomeerden van de bovengenoemde MBO- en HBOgezondheidszorgopleidingen. Voor de $\mathrm{MBO}^{\prime}$ ers betreft het de situatie circa éen jaar na het behalen van het diploma, terwijl het bij de HBO'ers om de situatie na ongeveer anderhalf jaar na afstuderen gaat.

Van alle gediplomeerde MBO-schoolverlaters blijkt ruim de helft zich aan te bieden op de arbeidsmarkt. Hiervan is slechts een klein deel werkzoekend. Ongeveer één op de drie MBOschoolverlaters is na de opleiding een vervolgopleiding gaan volgen. Daarnaast vervult $12 \%$ van schoolverlaters met een MBO-diploma zijn militaire of vervangende dienstplicht. Van de gediplomeerde schoolverlaters van het DGO-L-vp is bijna tweederde na de opleiding gaan

12. Hierbij dient men zich te realiseren dat bij het recruteren van helpenden in de praktijk niet alleen schoolverlaters van de twee hier genoemde leerlingwezenopleidingen worden aangetrokken. 
werken. Bij het DGO-L-Vz is dit zelfs $89 \%$. Van deze laatste groep heeft nog geen $10 \%$ voor een vervolgopleiding gekozen. Uit aanvullende gegevens uit het RUBS-onderzoek blijkt dat van de werkenden met een diploma DGO-L-vz slechts $5 \%$ in een niet-verpleegkundig/verzorgend beroep is terecht gekomen. Onder de werkende schoolverlaters van het DGO-L-vp heeft slechts $2 \%$ een baan buiten dit beroepsdomein.

Tabel 2.19. Bestemming van gediplomeerde schoolverlaters naar opleidingsrichting 1992.

\begin{tabular}{|c|c|c|c|c|c|}
\hline Opleiding & $\begin{array}{c}\text { werk }^{\mathrm{a}} \\
\%\end{array}$ & $\begin{array}{c}\text { studie } \\
\%\end{array}$ & $\begin{array}{c}\text { Bestemming } \\
\text { werkloos } \\
\%\end{array}$ & $\begin{array}{l}\text { dienstplicht } \\
\%\end{array}$ & $\begin{array}{c}\text { anders } \\
\%\end{array}$ \\
\hline DGO-L-vp & 62 & 34 & 1 & 1 & 1 \\
\hline DGO-L-Vz & 89 & 9 & 1 & 0 & 1 \\
\hline Totaal MBO & 51 & 34 & 2 & 12 & 1 \\
\hline HBO-v & 84 & 9 & 2 & 1 & 3 \\
\hline HBO-mgz & 87 & 3 & 6 & 0 & 5 \\
\hline Totaal HBO & 72 & 14 & 8 & 3 & 3 \\
\hline
\end{tabular}

Bron: RUBS 1992, HBO-Monitor 1992, ROA

Van alle pas afgestudeerden van het HBO heeft $72 \%$ een betaalde baan, terwijl $14 \%$ voor een vervolgstudie heeft gekozen. Daarnaast is $8 \%$ op het moment van de enquete werkzoekend en vervult nog eens $3 \%$ de dienstplicht. Onder de afgestudeerden met een HBO-v of een -mgzdiploma is het percentage werkenden relatief hoog. Zij zijn naar verhouding minder vaak verder gaan studeren, werkzoekend of in militaire dienst. Aanvullende gegevens uit de HBO-Monitor laten zien dat slechts $5 \%$ van de werkende afgestudeerden van het HBO-v en $7 \%$ van de werkende afgestudeerden van het HBO-mgz een beroep heeft dat niet tot de verpleegkundige of verzorgende beroepen wordt gerekend. 


\section{DE ARBEIDSMARKT IN DE ZORGSECTOR OP MIDDELLANGE TERMIJN}

\subsection{Inleiding}

Voorafgaand aan de bespreking van de lange-termijn-arbeidsmarktontwikkelingen in de zorgsector aan de hand van de CPB-scenario's, wordt in dit hoofdstuk eerst een raming voor de middellange termijn gepresenteerd, toegespitst op de vier onderscheiden beroepsgroepen. De middellange-termijn-ontwikkeling wordt daarbij niet gezien als een momentopname van léén van) de lange-termijn-scenario's, maar wordt, in navolging van het CPB, apart geanalyseerd. De prognoses worden derhalve gerelateerd aan de middellange-termijn-ramingen voor de periode 1993-1998, die zijn gepubliceerd in het Centraal Economisch Plan 1993 (CPB, 1993). Daarbij wordt, lettend op de huidige economische situatie, uitgegaan van het behoedzame scenario. Daarbij moet worden opgemerkt dat de economische groei in dit behoedzame scenario tot 1998 zelfs lager is dan bij het doormodder-scenario Global Shift. Binnen de CPB-raming voor de kwartaire dienstverlening wordt in dit hoofdstuk geen verdere invulling gegeven van het de komende jaren gevoerde overheidsbeleid ten aanzien van de zorgsector.

In het behoedzame CPB-scenario voor de middellange-termijn is er sprake van een beperkte werkgelegenheidsgroei van slechts $0,7 \%$ per jaar. De beroepsbevolking neemt naar verwachting iets sterker toe, zodat er per saldo een lichte stijging van de werkloosheid zal optreden. De werkgelegenheidsgroei in de kwartaire dienstverlening is echter aanmerkelijk groter dan het gemiddelde. Het CPB verwacht hier een toename van het aantal werkenden van gemiddeld $1,9 \%$ per jaar.

Bij de middellange-termijn-raming wordt er van uitgegaan dat de recente ontwikkelingen in het gebruik van de diverse zorgsectoren, voor zover relevant, zich voortzetten. Bovendien wordt rekening gehouden met de verwachte verschuivingen in de demografische opbouw van de bevolking. Verder wordt er vanuit gegaan dat er niet of nauwelijks aanvullende beleidsmaatregelen ten aanzien van de zorgsector worden getroffen die evidente trendbreuken zouden kunnen bewerkstelligen, anders dan reeds door het CPB is verdisconteerd in de raming van de werkgelegenheid in de kwartaire diensten.

Achtereenvolgens zal in dit hoofdstuk worden ingegaan op de verwachte uitbreidingsvraag, de vervangingsvraag, het aantal baanopeningen, de instroom van schoolverlaters en ten slotte de, op basis van deze onderliggende ontwikkelingen, verwachte toekomstige arbeidsmarktsituatie voor de vier onderscheiden beroepsgroepen. Deze prognoses hebben alle betrekking op de landelijke ontwikkeling. Daarnaast zal bij de bespreking van de uitbreidingsvraag ook een indicatie worden gegeven van de verschillen in de werkgelegenheidsontwikkeling tussen de provincies.

\subsection{Uitbreidingsvraag}

De toename en verdere vergrijzing van de bevolking, alsmede de trendmatige groei van de 
zorgbehoefte, leidt er toe dat de werkgelegenheid in de zorgsector in de periode 1993-1998 met ongeveer 40.000 arbeidsplaatsen zal toenemen. Dit komt neer op een gemiddelde jaarlijkse groei van $2,8 \%$, hetgeen duidelijk hoger is dan de werkgelegenheidsgroei van $1,9 \%$ die door het CPB voor de kwartaire diensten wordt verwacht. Dit stemt overeen met het feit dat ook in de afgelopen 15 jaar de werkgelegenheid in de zorgsector harder is gegroeid dan de werkgelegenheid in de totale kwartaire dienstverlening.

Een groot deel van de verwachte werkgelegenheidsgroei heeft te maken met de toenemende behoefte aan ouderenzorg vanwege de verdergaande vergrijzing van de bevolking van ons land. Doordat de vergrijzing een verhoudingsgewijs minder zware invloed heeft op de zorgvraag in de ziekenhuizen, zal in deze sector de werkgelegenheidstoename geringer zijn.

De forse werkgelegenheidsgroei in de ouderenzorg zorgt ervoor dat de uitbreidingsvraag naar verzorgenden eveneens relatief groot is. Tabel 3.1 laat zien dat er in de periode 1993-1998 in totaal ruim 12.000 nieuwe arbeidsplaatsen voor verzorgenden ontstaan. De gemiddelde jaarlijkse werkgelegenheidsgroei bedraagt daarmee ruim $5 \%$. De uitbreidingsvraag naar helpenden is relatief gering. De jaarlijkse stijging van het aantal arbeidsplaatsen bedraagt gemiddeld ongeveer $1 \%$. Per saldo betekent dit dat de werkgelegenheid voor helpenden in de periode 1993-1998 met 4.400 personen toeneemt.

Tabel 3.1. Uitbreidingsvraag per beroepsgroep 1993-1998 (totaal aantal en gemiddelde jaarlijkse groei)

\begin{tabular}{lcc}
\hline Beroepsgroep & aantal & $\%$ \\
\hline Verpleegkundigen & 13.100 & 2,4 \\
Ziekenverzorgenden & 10.300 & 3,9 \\
Verzorgenden & 12.300 & 5,1 \\
Helpenden & 4.400 & 1,1 \\
Totaal & 40.100 & 2,8 \\
\hline
\end{tabular}

Bron: ROA

De relatieve werkgelegenheidsgroei voor verpleegkundigen is iets lager dan het gemiddelde. Absoluut gezien is de uitbreidingsvraag voor deze beroepsgroep echter het grootst. Voor ziekenverzorgenden wordt een bovengemiddelde werkgelegenheidsgroei van 3,9\% per jaar verwacht. Ook dit heeft te maken met de toenemende zorgvraag als gevolg van het groter aantal ouderen in ons land.

\section{Regionale prognoses}

De werkgelegenheidsontwikkeling in de zorgsector is niet in iedere provincie gelijk. In een qua bevolking sterk groeiende provincie als Flevoland is de verwachte werkgelegenheidstoename in het algemeen hoger. Ook in provincies waar de bevolking sterker vergrijst dan landelijk het geval 
is, zal de uitbreidingsvraag in de zorgsector groter zijn. Tabel 3.2 geeft een beeld van de afwijking van de provinciale werkgelegenheidsgroei ten opzichte van de landelijke prognose.

Zoals mocht worden verwacht, neemt vooral in de provincie Flevoland de werkgelegenheid fors toe. De verwachte werkgelegenheidstoename in de zorgsector is in deze provincie maar liefst $10 \%$-punt hoger dan het landelijk gemiddelde. Ook in Noord-Brabant en Limburg wordt er een bovengemiddelde groei van de werkgelegenheid verwacht. Dit heeft vooral te maken met de in deze provincies iets sterkere vergrijzing van de bevolking. In de provincies Groningen en Friesland, alsook in Noord-Holland, Zuid-Holland en Zeeland is de toename van het aantal ouderen verhoudingsgewijs lager dan in de rest van Nederland. Daardoor wordt er voor deze provincies een iets lagere groei van de werkgelegenheid verwacht dan voor de rest van Nederland.

Voor de onderscheiden beroepsgroepen is het beeld ongeveer gelijk aan het totaalbeeld per provincie. In Drenthe is er echter naar verwachting een grotere werkgelegenheidsgroei voor de verpleegkundigen. Voor Gelderland is er daarentegen sprake van een bovengemiddelde werkgelegenheidsgroei voor de helpenden. Tegen het provinciale beeld in geldt voor de provincie Zuid-Holland dat de verwachte werkgelegenheidsgroei voor helpenden ongeveer gelijk is aan het landelijk gemiddelde.

Tabel 3.2. Uitbreidingsvraag per beroepsgroep en provincie 1993-1998 (afwijking ten opzichte van het landelijke beeld)

$\begin{array}{lllllllllllllllllllll}\text { Beroepsgroep } & \text { GR } & \text { FR } & \text { DR } & \text { OV } & \text { GL } & \text { UT } & \text { NH } & \text { ZH } & \text { ZL } & \text { NB } & \text { LB } & \text { FL } & \text { NL }\end{array}$

verpleegkundigen

Ziekenverzorgenden

Verzorgenden

Helpenden

Totaal

_- = provinciale groei is tenminste $2 \%$-punt lager dan landelijke groei

- $\quad=$ provinciale groei is tussen $1 \%$-punt en $2 \%$-punt lager dan landelijke groei

$0=$ provinciale groei is ongeveer gelijk aan het landelijk gemiddelde

$+\quad=$ provinciale groei is tussen $1 \%$-punt en $2 \%$-punt hoger dan landelijke groei

$++=$ provinciale groei is tenminste $2 \%$-punt hoger dan landelijke groei

Bron: ROA

\subsection{Vervangingsvraag}

Naast de uitbreidingsvraag bestaat er een grote behoefte aan schoolverlaters vanwege de vervangingsvraag. Deze vervangingsvraag ontstaat in de eerste plaats doordat arbeidskrachten zich van de arbeidsmarkt terugtrekken in verband met pensionering, arbeidsongeschiktheid e.d. In de zorgsector waar relatief veel vrouwen werkzaam zijn is er daarnaast een belangrijke 
uitstroom van werkenden vanwege de geboorte en opvoeding van de kinderen. Ook ontstaat er een vervangingsbehoefte doordat mensen de zorgsector verlaten en zich op een ander arbeidsmarktsegment aanbieden. Aan de andere kant zijn er echter ook arbeidskrachten die vanuit andere bedrijfssectoren instromen in de zorgsector. Daarnaast is er in de zorgsector een zeer omvangrijke instroom van herintredende vrouwen. Deze instroom van herintreders wordt in dit rapport niet expliciet in kaart gebracht, maar wordt volledig verdisconteerd met de vervangingsvraag ${ }^{13}$. Als gevolg daarvan is de totale vervangingsbehoefte aan schoolverlaters lager dan het totale netto verloop. Tabel 3.3 geeft een overzicht van de verwachte vervangingsvraag naar schoolverlaters in de periode 1993-1998, verbijzonderd naar beroepsgroep.

De totale vervangingsvraag naar schoolverlaters in de zorgsector bedraagt ruim 40.000 personen, ofwel gemiddeld 3\% per jaar. Erg opvallend is daarbij de lage vervangingsvraag naar verzorgenden. De totale vervangingsbehoefte aan schoolverlaters bedraagt voor deze beroepsgroep in de periode 1993-1998 slechts 600 personen, overeenkomend met jaarlijks $0,3 \%$ van de werkgelegenheid. Dit komt omdat vooral in de gezinszorg een groot gedeelte van de uitstroom zal kunnen worden opgevangen door herintreders en degenen die vanuit andere sectoren overstappen naar een (deeltijd)baan in de zorgsector. Ook bij de helpenden is de vervangingsbehoefte aan schoolverlaters relatief laag.

Tabel 3.3. Vervangingsvraag naar schoolverlaters per beroepsgroep 1993-1998 (totaal aantal en gemiddeld jaarlijks percentage)

\begin{tabular}{lrr} 
Beroepsgroep & aantal & $\%$ \\
\hline verpleegkundigen & 24.500 & 4,3 \\
Ziekenverzorgenden & 11.100 & 4,2 \\
Verzorgenden & 600 & 0,3 \\
Helpenden & 7.300 & 1,9 \\
Totaal & 43.600 & 3,0 \\
\hline
\end{tabular}

Bron: ROA

De totale vervangingsbehoefte aan schoolverlaters met een opleiding tot verpleegkundige is ruim $4 \%$ gemiddeld per jaar. In de periode 1993-1998 bedraagt de vervangingsvraag naar verpleegkundigen in totaal bijna 25.000 personen, hetgeen betekent dat meer dan de helft van de totale vervangingsbehoefte in de zorgsector betrekking heeft op verpleegkundigen. De vervangingsvraag naar ziekenverzorgenden is de komende vijf jaar ruim 11.000 personen.

13. Dit betekent dat ook de uitbreidingsvraag, als gepresenteerd in paragraaf 3.2, volledig door schoolverlaters moet worden opgevuld. 


\subsection{Baanopeningen}

De uitbreidingsvraag en de vervangingsvraag vormen samen het totaal aantal baanopeningen voor schoolverlaters. In tabel 3.4 wordt een overzicht gegeven van het totaal aantal verwachte baanopeningen in de periode 1993-1998, verbijzonderd naar beroepsgroep. Tevens is in de tabel een onderscheid gemaakt naar het aandeel van de uitbreidingsvraag en de vervangingsvraag in het totaal aantal baanopeningen.

De totale voor de middellange termijn verwachte behoefte aan bijna 84.000 schoolverlaters in de zorgsector hangt voor $48 \%$ samen met de werkgelegenheidsgroei en voor de resterende $52 \%$ met de vervangingsvraag. Tussen de diverse beroepsgroepen in de zorg zijn er op dit punt echter grote verschillen. Van het totaal aantal baanopeningen zijn er meer dan 37.000, ofwel ongeveer $45 \%$, voor verpleegkundigen. In verhouding tot het totale werkgelegenheidsaandeel van verpleegkundigen in de zorgsector van circa $20 \%$ is dat erg veel. Ongeveer twee derde van de totale vraag naar verpleegkundigen hangt samen met de vervangingsbehoefte. Ook voor de helpenden wordt het merendeel van de in totaal bijna 12.000 baanopeningen veroorzaakt door de vervangingsvraag. Bij de ziekenverzorgenden is de totale vraag ongeveer gelijk verdeeld over de uitbreidings- en de vervangingsvraag. Opvallend is echter het beeld bij de verzorgenden: van de in totaal 13.000 baanopeningen in de periode $1993-1998$ is slechts $5 \%$ het gevolg van de vervangingsbehoefte. Dit lage percentage is zowel het gevolg van een relatief hoge uitbreidingsvraag, als van een verhoudingsgewijs lage vervangingsbehoefte.

Tabel 3.4. Aantal baanopeningen en verdeling over uitbreidingsvraag en vervangingsvraag per beroepsgroep 1993-1998

\begin{tabular}{lccc}
\hline Beroepsgroep & aantal & $\begin{array}{c}\text { uitbreidingsvraag } \\
\%\end{array}$ & $\begin{array}{c}\text { vervangingsvraag } \\
\%\end{array}$ \\
& & & 65 \\
Verpleegkundigen & 37.600 & 45 & 52 \\
Ziekenverzorgenden & 21.400 & 95 & 5 \\
Verzorgenden & 13.000 & 38 & 62 \\
Helpenden & 11.700 & 48 & 52 \\
Totaal & 83.700 & &
\end{tabular}

Bron: ROA

\subsection{Instroom van schoolverlaters}

De totale behoefte aan schoolverlaters in de periode 1993-1998 zou moeten worden opgevangen door de arbeidsmarktinstroom van schoolverlaters vanuit de opleidingen die zijn gericht op de verpleegkundige en verzorgende beroepen in de gezondheidszorg. Tabel 3.5 geeft aan hoe groot de instroom van schoolverlaters in de periode 1993-1998 voor de onderscheiden beroepsgroepen naar verwachting zal zijn. 
Tabel 3.5. Instroom van schoolverlaters per beroepsgroep 1993-1998 (totaal aantal en gemiddeld jaarlijks percentage)

\begin{tabular}{lrc}
\hline Beroepsgroep & aantal & $\%$ \\
\hline Verpleegkundigen & 33.800 & 5,7 \\
Ziekenverzorgenden & 16.900 & 6,2 \\
Verzorgenden & 16.500 & 6,7 \\
Helpenden & 4.000 & 1,0 \\
Totaal & 71.200 & 4,8 \\
\hline
\end{tabular}

Bron: ROA

In totaal stromen er de komende vijf jaar ruim 70.000 schoolverlaters in op de arbeidsmarkt in de zorgsector. Het merendeel daarvan heeft een opleiding tot verpleegkundige gevolgd. In de periode 1993-1998 zullen bijna 34.000 schoolverlaters vanuit de opleidingen dit arbeidsmarktsegment instromen. Dit is gemiddeld jaarlijks bijna $6 \%$ van de werkgelegenheid. Voor de ziekenverzorgenden en de verzorgenden worden voor de middellange termijn iets hogere instroompercentages verwacht van ruim $6 \%$ tot bijna $7 \%$ gemiddeld per jaar.

Voor de beroepsgroep helpenden wordt slechts een zeer geringe (directe) arbeidsmarktinstroom van schoolverlaters verwacht. In totaal bieden zich in de periode 1993-1998 slechts 4.000 schoolverlaters zich voor deze beroepsgroep aan. Daarbij moet wel worden bedacht dat voor het beroep van helpenden in de praktijk de opleidingseisen minder stringent zijn. Aangezien er in het algemeen sprake zal zijn van een ruime arbeidsmarkt voor VBO-opgeleiden in de meer verzorgende richtingen (zie ROA,1993), zal door de zorgsector relatief eenvoudig extra aanbod van schoolverlaters, eventueel na bijscholing, kunnen worden gerecruteerd. Bovendien zou een deel van de werkzaamheden van helpenden ook door alpha-hulpen e.d. kunnen worden verricht.

\subsection{Toekomstige arbeidsmarktsituatie}

De vergelijking van de toekomstige vraag- en aanbodstromen geeft het in tabel 3.6 weergegeven beeld van aanbod- en vraagoverschotten. Gezien de in de vorige paragraaf aangegeven verwachte lage directe arbeidsmarktinstroom van helpenden is het niet verrassend dat deze beroepsgroep geconfronteerd wordt met het grootste aanbodtekort. Zoals echter reeds is opgemerkt, mag echter worden aangenomen dat bij de verwachte ruime arbeidsmarkt voor VBO-opgeleiden in het algemeen de recrutering van helpenden toch weinig problematisch zal zijn. Het 'ex ante' verwachte tekort bij de beroepsgroep helpenden zal derhalve waarschijnlijk feitelijk niet of nauwelijks optreden.

Voor de ziekenverzorgenden is het probleem echter nijpender. Er wordt voor deze beroepsgroep een tekort aan 4.500 schoolverlaters verwacht. Dit betekent dat bijna $8 \%$ van de arbeidsplaatsen in 1998 niet kan worden vervuld. Met name de verpleeghuizen krijgen hierdoor te kampen 
met een tekort aan arbeidskrachten, hetgeen ongetwijfeld invloed zal hebben op de werkdruk in deze sector. Er wordt voor de middellange termijn eveneens een, zij het wat geringer tekort aan verpleegkundigen verwacht. Dit kan in vrijwel alle sectoren leiden tot knelpunten bij de werving van nieuwe arbeidskrachten. Gezien de verwachte verschillen in de werkgelegenheidsgroei tussen de provincies, mag worden aangenomen dat vooral de provincies Noord-Brabant en Limburg te kampen krijgen met recruteringsproblemen van verpleegkundigen en ziekenverzorgenden. In de provincies Groningen, Friesland, Zeeland en Noord-Holland treden er mogelijk minder grote knelpunten op. De grote werkgelegenheidsgroei die voor de provincie Flevoland wordt verwacht, kan waarschijnlijk worden opgevangen door een arbeidsmarktinstroom van schoolverlaters uit de omringende provincies.

Tabel 3.11. Aanbodoverschot of -tekort per beroepsgroep in 1998 (totaal aantal en relatief ten opzichte van de verwachte vraag in 1998)

\begin{tabular}{lrr} 
Beroepsgroep & aantal & $\%$ \\
\hline Verpleegkundigen & & $-3,2$ \\
Ziekenverzorgenden $_{\text {Verzorgenden }}$ & -3.800 & $-7,7$ \\
Helpenden $^{\mathrm{a}}$ & -4.500 & 6,3 \\
& 3.500 & $-9,6$ \\
Totaal & -7.800 & $-4,0$
\end{tabular}

a Vanwege de verwachte ruime arbeidsmarkt voor VBO-opgeleiden in de verzorgende richting in het algemeen, zal dit tekort feitelijk niet optreden.

Bron: ROA

Het aanbod van schoolverlaters met een opleiding tot verzorgende is ruim voldoende om aan de totale vraag te voldoen. Het aanbodoverschot bedraagt bijna 4.000 personen, hetgeen overeenkomt met circa $6,5 \%$ van de verwachte vraag naar arbeidskrachten in 1998. Vanwege de grote verwachte werkgelegenheidsgroei voor verzorgenden in de ouderenzorg kunnen er bij deze zorgvoorzieningen overigens wel enige recruteringsproblemen voorkomen. 


\section{TOEKOMSTSCENARIO'S VOOR DE NEDERLANDSE ECONOMIE}

\subsection{Inleiding}

Het CPB heeft in 1992 voor de derde maal een lange-termijn-raming van de Nederlandse economie opgesteld: Nederland in Drievoud (CPB, 1992a). In tegenstelling tot de eerdere langetermijn-ramingen waarbij een lage, een hoge en een middenvariant werd opgesteld, geeft de meest recente scenariostudie meer de mogelijke bandbreedten van de toekomstige ontwikkelingen van de Nederlandse economie aan, mede onderbouwd op basis van mogelijke ontwikkelingen in de wereldeconomie. Deze lange-termijn-scenario's voor de wereldeconomie zijn gepresenteerd in het rapport Scanning the future (CPB, 1992b). In de CPB-studie worden voor de Nederlandse economie drie toekomstscenario's uitgewerkt voor de periode 1990-2015:

- Global Shift (GS);

- Balanced Growth (BG);

- European Renaissance (EUR).

In dit hoofdstuk wordt ingegaan op de hoofdlijnen van deze scenario-studie. Vanzelfsprekend wordt daarbij de nadruk gelegd op de verwachte ontwikkeling van de zorgsector binnen de scenario' $s^{14}$. Ook de aan deze ontwikkelingen mede ten grondslag liggende veronderstellingen over de wereldeconomie en de (totale) Nederlandse economie worden echter kort besproken. Per scenario wordt achtereenvolgens aandacht besteed aan:

- internationale ontwikkelingen;

- nationale ontwikkelingen;

- ontwikkelingen op de arbeidsmarkt;

- ontwikkelingen in de gezondheidszorg.

Vervolgens worden de drie scenario's nog eens kort samengevat en met elkaar vergeleken. Daarbij wordt bovendien nagegaan welke gevolgen de verschillende scenario's hebben voor de werkgelegenheidsontwikkeling in Nederland in het algemeen en voor de zorgsector in het bijzonder.

\subsection{Global Shift}

\section{Internationale ontwikkelingen}

Binnen het Global Shift scenario is er op wereldschaal sprake van een zeer snelle technologische ontwikkeling. Deze technologische ontwikkeling doet zich met name voor in Oost-Azië, Japan en de Verenigde Staten. Het economisch zwaartepunt verschuift daardoor verder naar de

14. Bij de beschrijving van de gezondheidszorg is, behalve van het rapport Nederland in drievoud, veelal gebruik gemaakt van het CPB-Onderzoeksmemorandum dat specifiek op de toekomstscenario's in de zorgsector is gericht (Zant, 1992). Overigens moet worden beseft dat het CPB in deze studie de gehele sector 'Overig kwartair' als de zorgsector bestempeld. Deze sector bevat bijvoorbeeld ook de 'Maatschappelijke dienstverlening e.d.' en 'Cultuur, sport en recreatie'. 
Verenigde Staten, Japan en de Dynamic Asian Economics (DAE's). Noodzakelijke voorwaarden voor deze snelle technologische ontwikkeling zijn onder meer creatief ondernemerschap en een sterke concurrentie. Op wereldschaal vindt er in dit scenario een vergaande liberalisering van de handel plaats, waarbij het Vrije-Markt-perspectief ${ }^{15}$ overheerst.

Het Global Shift scenario gaat er echter vanuit dat er binnen Europa in de periode 1990-2005 geen verdergaande liberalisering van de internationale handel plaatsvindt. Het scenario veronderstelt een stagnatie van de Europese integratie. De nationale overheden gaan de toetredings-belemmeringen tot de eigen markten verhogen, omdat Europa de technologische ontwikkeling in de Verenigde Staten, Japan en de DAE's niet kan volgen. De toenemende stagnatie van de Europese economie leidt er toe dat nationalistische en protectionistische tendensen binnen Europa aan kracht winnen. Het scenario wordt erg typerend ook wel aangeduid als het 'doormodder-scenario'.

Rond het jaar 2005 bereikt de economische positie van West-Europa een dieptepunt. Het Global Shift scenario verwacht dat er vanaf 2005 in Europa een scherpe bewustwording ontstaat voor de precaire situatie waarin de economie verkeert. Men wordt zich er van bewust dat krachtige veranderingen noodzakelijk zijn om de welvaartsgroei in Europa te continueren. Dit zal resulteren in harde maatregelen om de bestaande rigiditeiten op de goederenmarkt en de arbeidsmarkt te doorbreken. Door een sterke beleidsconcurrentie tussen de lidstaten van de Europese Gemeenschap (EG) komt de verdere Europese integratie tot stand. Verder worden in dit scenario in de periode na 2005 de Europese verzorgingsstaten in versneld tempo versoberd en vereenvoudigd.

\section{Nationale ontwikkelingen}

In het Global Shift scenario heeft Nederland als klein land verhoudingsgewijs veel hinder van het stagneren van de Europese integratie en van het blijven voortbestaan van toetredingsbarrières tot nationale markten. Het wordt duidelijk dat de Nederlandse economie in belangrijke mate is gespecialiseerd in activiteiten die naar verwachting op langere termijn slechts een zeer beperkte groei zullen kennen. Om en nabij het jaar 2005 dringt het besef door dat de Nederlandse economie moet worden geherstructureerd in de richting van hoogwaardiger en meer kennisintensieve marktsegmenten.

15. Het Vrije-Marktperspectief is ontleend aan de Oostenrijkse school van Schumpeter en Hayek. Verondersteld wordt dat economische vooruitgang gepaard gaat met pijnlijke aanpassingsprocessen. De technologische vooruitgang wordt in grote mate bepaald door het bestaan van vele concurrentievormen. Dit houdt automatisch in dat er naast 'winnaars' ook 'verliezers' zullen zijn. De markt bepaalt hoe de economie zich ontwikkelt en welke technologische vernieuwingen succesvol zijn. De rol van de overheid is in dit perspectief zeer beperkt. $\mathrm{Er}$ is in dit perspectief een grote aversie tegen staatsbedrijven en zelfs de 'klassieke' overheidstaken worden sceptisch behandeld. Essentieel is dat de overheid evenveel onzekerheid over de toekomst heeft als de bedrijven. Aangezien echter verkeerde overheidsbeslissingen niet (kunnen) worden gecorrigeerd door de markt, kan verkeerd overheidsbeleid lang standhouden. 
$\mathrm{Er}$ is in dit scenario sprake van toenemende migratie en een verdergaande inactiviteit van de potentiële beroepsbevolking, hetgeen voortdurende overschrijdingen van de Rijksbegroting tot gevolg heeft. Samenhangend hiermee zullen hervormingen van het openbaar bestuur in de zin van meer financiële en bestuurlijke verzelfstandiging op niets uitlopen. De overheid probeert in het Global Shift scenario het in 1991 ingezette beleid ter beperking van het aantal arbeidsongeschikten en het ziekteverzuim, door te zetten. In de loop van de jaren negentig zal echter blijken dat dit beleid slechts in beperkte mate effectief is. Het Global Shift scenario verwacht dat het aantal arbeidsongeschikten in de loop van de jaren negentig weer gaat stijgen. Na het jaar 2000 zal dit aantal oplopen tot meer dan 1.250.000.

\section{Ontwikkelingen op de arbeidsmarkt}

Het Global Shift scenario veronderstelt dat de Nederlandse arbeidsmarkt, zoals ook momenteel het geval is, wordt gekenmerkt door een beperkte flexibiliteit. De koopkrachtontwikkeling van de uitkeringen blijft ongeveer parallel verlopen met de lonen, hetgeen tot gevolg heeft dat de replacement rate ${ }^{16}$ niet lager wordt en ook het reserveringsloon ${ }^{17}$ slechts weinig verandert. Het Global Shift scenario veronderstelt tevens dat er in toenemende mate sprake zal zijn van insiders-outsiders effecten ${ }^{18}$ en een afwenteling van de collectieve lastendruk. Als gevolg daarvan vindt er in onvoldoende mate een afname plaats van de reële loonvoet, waardoor de arbeidsinkomensquote stijgt. Het uiteindelijke gevolg hiervan is, dat er een sterk duale arbeidsmarkt tot stand komt met aan de ene kant goed opgeleide, relatief baanzekere werknemers en aan de andere kant een groeiende groep, vaak laaggeschoolde, langdurig werklozen en arbeidsongeschikten. Tot deze groep behoort een groeiend aantal allochtonen. In dit scenario wordt aangenomen dat het aantal werklozen en arbeidsongeschikten tegen het jaar 2005 tot boven de twee miljoen gestegen is.

De overheid gaat, als reactie op de toenemende werkloosheid, een activerend arbeidsmarktbeleid voeren. Zo zullen scholingsfaciliteiten en werkervaringsplaatsen worden uitgebreid. Dit activerende arbeidsmarktbeleid zal worden geflankeerd door een harder sanctiebeleid in de sociale zekerheid. Dit beleid zal echter weldra vastlopen omdat aan de ene kant de dalende werkgelegenheid in de bedrijvensector een vlotte uitstroom vanuit de arbeidsmarktprogramma's naar arbeidsplaatsen in de marktsector verhindert en aan de andere kant het aanbod voor deze programma's door de toenemende werkloosheid en immigratie blijft stijgen. Als gevolg daarvan verdwijnt in Global Shift de consensus tussen overheden, uitvoeringsorganisaties en sociale partners om tot aanscherping van het sanctiebeleid te komen. Op lange termijn zal blijken dat

16. De replacement rate is de verhouding tussen de netto sociale uitkering en het bij werken te verdienen netto loon.

17. Het reserveringsloon is het minimale loon waarbij een werkloze bereid is een baan te accepteren.

18. Onder insiders-outsiders effecten wordt verstaan dat de uitkomst van de loononderhandelingen in grote mate worden bepaald door de werkzame, baanzekere en beter geschoolde werknemers (insiders), terwijl de belangen van werklozen, herintreders en migranten (outsiders) slechts een minimale invloed op het loonvormingsproces hebben. Dit heeft tot gevolg dat er eerder een stijging van de reële lonen zal plaatsvinden dan een toename van het aantal arbeidsplaatsen. 
het systeem sociaal en economisch onaanvaardbaar is en zal men er rond 2005 toe over gaan diverse beleidsmaatregelen versneld door te voeren.

\section{Ontwikkelingen in de gezondheidszorg}

In het Global Shift scenario wordt er van uitgegaan dat in de periode 1990-2005 geen efficiëntieverbeteringen in de gezondheidszorg worden gerealiseerd. De volumegroei van de kwartaire diensten blijft gelijk opgaan met de groei van het reële nationaal inkomen. Door de grote interne verdeeldheid tussen de verschillende belangengroepen (de aanbieders van zorg, de zorgverzekeraars, de consumentenorganisaties en de vakbonden), zal het niet mogelijk blijken te zijn een stelselherziening door te voeren. De pogingen van de overheid om fundamentele veranderingen in het stelsel van de gezondheidszorg aan te brengen, ketsen af op dit gebrek aan consensus. De plannen van de commissie Dekker en het plan Simons zijn definitief van de baan.

Dit alles zal er toe leiden dat het huidige systeem van aanbodwetgeving als beheersingsinstrument van de overheid zal blijven bestaan, evenals de bestaande financieringsstructuur. De overheid zal op de stijgende kosten reageren met een nog stringenter budgetteringsbeleid. Het probleem daarbij is echter dat op den duur de budgettering niet meer zal werken, door al dan niet bewuste overschrijdingen van de opgelegde budgetten door de zorgaanbieders. Deze laatste worden daarbij gesteund door de publieke opinie vanwege de steeds langere wachttijden in de gezondheidszorg of de uitsluiting van bepaalde vormen van zorg op basis van onvoldoende urgentie.

Het Global Shift scenario gaat er verder van uit dat de machtspositie van de aanbieders van zorg gehandhaafd blijft. Dit zal er toe leiden dat er slechts een zeer beperkte produktiviteitsstijging zal plaatsvinden. Ook inefficiënties in het aanbod van zorg kunnen blijven voortbestaan. Als gevolg hiervan gaan particuliere zorgverzekeraars een sterkere risico-selectie toepassen. Doordat meer mensen via de Wet Toegang Ziektekostenverzekering (WTZ), in een standaardpakketpolis terecht zullen komen, zullen de verzekeringspremies sterk toenemen, mede als gevolg van hogere 'poolingsbijdragen', die moeten worden betaald als solidariteit met andere, moeilijk verzekerbare, personen (bijvoorbeeld bejaarden). Door aanbodrantsoenering van zorg vanuit de overheid, zal de zorgsector zich buiten het officiële circuit verder ontwikkelen. Vragers en aanbieders van zorgverlening omzeilen de officiële zorginstellingen om zo de wachttijden en de beperkte behandelingsmethode te vermijden.

Verwacht wordt dat het Global Shift scenario tevens zal leiden tot een ongebreidelde groei van medische technologie, omdat de medici bij het toepassen van nieuwe technologieën zich louter laten leiden door medische overwegingen. De kostenaspecten zijn niet of nauwelijks van belang, daar deze altijd worden vergoed en niet voor concurrentie hoeft te worden gevreesd. De technologische ontwikkeling zal vooral plaatsvinden in de intramurale zorg en veel minder in de extramurale zorg, daar er in de extramurale zorg slechts beperkte mogelijkheden zijn om inkomensgenererende technologieën te implementeren. 
Rond het jaar 2005 heeft in de gezondheidszorg evenals in andere bedrijfssectoren een abrupte beleidsreactie plaats. Door de opgelopen premiedruk, de forse solidariteitsheffingen en de inflexibele, inefficiënte en patiëntvriendelijke zorgverlening, is de tijd rijp om in snel tempo het stelsel van de gezondheidszorg te reorganiseren. Deze reorganisatie gaat gepaard met een drastische sanering voor zowel de aanbodzijde als voor de verzekeraars. De prijsstijgingen blijven na 2005 beperkt, zodat de collectieve lastendruk van de gezondheidszorg nauwelijks meer stijgt.

\subsection{Balanced Growth}

\section{Internationale ontwikkelingen}

In het Balanced Growth scenario wordt verondersteld dat er op wereldschaal sprake is van een "krachtige, multipolaire economische groei, waarin tevens belangrijke vorderingen worden gemaakt op weg naar een ecologisch duurzame ontwikkeling" (CPB, 1992a, blz. 112). Deze sterke economische groei kan tot stand komen doordat er in dit scenario, om in CPB-termen te spreken, een evenwicht tussen het Vrije-Markt-perspectief en het Coördinatie-perspectief ${ }^{19}$ wordt gevonden. Dit heeft als gevolg dat daar waar mogelijk de handel wordt geliberaliseerd en dat daar waar marktfalen wordt geconstateerd de overheden op verantwoorde wijze ingrijpen. Deze ontwikkeling zal er zelfs toe leiden dat Afrika en Latijns-Amerika een substantiële economische groei van ongeveer $5 \%$ per jaar gaan realiseren.

Voor Europa schetst Balanced Growth het beeld van een vergaande liberalisering van de internationale handel. Toetredingsbelemmeringen op de goederenmarkten, de arbeidsmarkt, alsmede op de markt voor technologische kennis zullen worden geslecht. Daardoor is een snelle diffusie van technologische innovaties mogelijk en wordt de concurrentie bevorderd. Het Europese integratieproces ontwikkelt zich 'bottom-up' als gevolg van marktkrachten en beleidsconcurrentie tussen de nationale overheden van de lidstaten. De EG zal zich verder ontwikkelen binnen het kader van de interne markt en de Economische en Monetaire Unie (EMU). De Europese integratie zal zich echter beperken tot economische integratie.

\section{Nationale ontwikkelingen}

In Nederland vindt een herdefiniëring van de rol van de overheid plaats. De overheid gaat evenals in de rest van de wereld meer aandacht besteden aan het stimuleren van marktwerking en concurrentie. Tevens concentreert de overheid zich meer op de uitvoering van de klassieke

19. Het Coördinatieperspectief is vooral gebaseerd op het gedachtengoed van Keynes. Daarbij wordt er vanuit gegaan dat door het bestaan van onzekerheid, rationeel gedrag op individueel niveau kan leiden tot onevenwichtigheden op macro-niveau. Door deze onzekerheid gaan ook niet strikt economische overwegingen een belangrijke rol spelen. Volgens Keynes kan economische vooruitgang vooral worden bevorderd door stabilisering van toekomstverwachtingen. Het overheidsbeleid wordt dan ook gekenmerkt door een stabiliserend monetair en budgettair beleid en door diverse vormen van regelgeving. 
overheidstaken zoals openbaar bestuur, onderwijs en infrastructuur. Daarbij zal de overheid haar regelgeving zoveel mogelijk beperken. Ook vindt er een fundamentele herziening plaats van de verzorgingsstaat en het belastingstelsel. Dit heeft een aantal opvallende gevolgen:

- de duur van de loongerelateerde uitkeringen wordt beperkt tot maximaal 2 jaar;

- er wordt een stelsel met een negatieve inkomstenbelasting ingevoerd (basisinkomen), waardoor het minimumloon overbodig wordt;

- het belastingstelsel wordt volledig geïndividualiseerd, dat wil zeggen dat er noch een toets op het partnerinkomen noch een toets op de woonsituatie zal plaatsvinden.

\section{Ontwikkelingen op de arbeidsmarkt}

Voor de arbeidsmarkt veronderstelt het Balanced Growth scenario dat de overheid de regelgeving met betrekking tot de ontslagwetgeving en de flexibele arbeidsrelaties versoepelt. Bovendien wordt ervan uitgegaan dat de overheid zich in gaat spannen om de vrije vestiging van 'vrije' beroepsbeoefenaren (notarissen, medisch specialisten e.d.) te bevorderen. Mede hierdoor, alsmede door de wijzigingen in het belastingstelsel zal de werkloosheid op termijn dalen tot een frictieniveau $(2,5 \%)$. Bovendien is de werkloosheid gelijkmatiger over de verschillende opleidingscategorieën verspreid.

\section{Ontwikkelingen in de gezondheidszorg}

Binnen het Balanced Growth scenario wordt er van uitgegaan dat de overheid er in slaagt een verdergaande stelselwijziging in de gezondheidszorg door te voeren. In het nieuwe stelsel zal $85 \%$ van de zorgsector in een basisverzekering worden ondergebracht. Van deze $85 \%$ zal $60 \%$ punt worden geïnd door de belastingdienst op basis van inkomensafhankelijke premies. Daarnaast zal 20\%-punt via nominale premies, vrijwillige eigen risico's en/of eigen bijdragen worden geïnd door de zorgverzekeraars. Ten slotte wordt $5 \%$-punt gefinancierd via verplichte eigen bijdragen en eigen risico's. De inkomensafhankelijke premies worden in een centrale kas gestort waarna deze naar rato van de ingebrachte risico's over de verzekeraars worden verdeeld. De overheid zorgt er voor dat het basispakket aan zorg wordt gegarandeerd en waakt ook over de kwaliteit van de gezondheidszorg. Het Balanced Growth scenario veronderstelt tevens dat de overheid het vestigingsbeleid voor de aanbieders van zorg afschaft. Daarbij kan zich echter een probleem voordoen ten aanzien van de toegankelijkheid van voorzieningen die niet in het basispakket zijn opgenomen. Deze voorzieningen zouden onbereikbaar kunnen worden voor de sociaal zwakkeren in de samenleving.

Het Balanced Growth scenario gaat er bovendien van uit dat het voor alle partijen in de zorgsector is toegestaan om winst te maken. Verder krijgen de zorgverzekeraars de verantwoordelijkheid voor uitvoerende werkzaamheden met betrekking tot de financiering van de individuele zorgconsumptie. Hier staat echter wel tegenover dat voor het basispakket geen enkele vorm van risicoselectie is toegestaan. Voor de aanvullende verzekeringen zijn vormen van selectie, eigen risico of verandering van de inhoud van het pakket daarentegen wel toegestaan. Deze grotere financiële verantwoordelijkheid betekent dat ziekenfondsen deskundigheid op het gebied 
van vermogensbelegging moeten gaan ontwikkelen. Aangezien ziekenfondsen hier weinig ervaring mee hebben, is het niet uitgesloten dat een sanering van enige ziekenfondsen zal plaatsvinden.

De grotere financiële onafhankelijkheid van de zorgverzekeraars zal er tevens toe leiden dat de verzekeraars de aanbieders van zorg kritisch gaan beoordelen op de diensten die zij aanbieden en meer belang zullen gaan hechten aan kosten- en efficiency-overwegingen bij de keuze van zorgaanbieders voor het pakket dat zij de verzekerden gaan aanbieden. De reden hiervoor is dat verzekerden vrij zijn in de keuze van hun zorgverzekeraar en bovendien vrij zijn om van verzekeraar te veranderen. Het Balanced Growth scenario veronderstelt dat door deze toename van de concurrentie in de zorgsector bij zowel zorgverzekeraars als bij zorgaanbieders een relatief hoge produktiviteitsstijging wordt gerealiseerd.

Zoals reeds werd aangegeven, is binnen dit scenario de economische groei hoog. Dit vereenvoudigt de financiering van technologische vernieuwingen binnen zowel de intramurale als de extramurale zorgsector. Bovendien worden technologische vernieuwingen binnen dit scenario bevorderd, omdat ze een belangrijk middel zijn in de concurrentiestrijd tussen zorgaanbieders. Desalniettemin zullen bij dergelijke investeringsbeslissingen, als gevolg van de heersende concurrentieverhoudingen, kostenoverwegingen belangrijk zijn. De zorgaanbieders worden derhalve aan de ene kant geconfronteerd met de noodzaak om door technologische vernieuwingen hun concurrentiepositie te versterken, terwijl zij aan de andere kant worden beperkt door budgetrestricties en verlies aan omzet door te hoge prijzen. Daarbij kunnen overschrijdingen van het budget uiteindelijk zelfs leiden tot een faillissement. De toename van concurrentie en de hieruit voortvloeiende toename van de efficiëntie in de gezondheidszorg, zullen er echter niet toe leiden dat er een eind komt aan de ontwikkeling van de stijgende kosten in de gezondheidszorg.

\subsection{European Renaissance}

\section{Internationale ontwikkelingen}

Het European Renaissance scenario veronderstelt dat de wisselwerking tussen technologische ontwikkeling, schaalfactoren en internationalisatie op langere termijn tot minder competitieve marktstructuren zal leiden. Er ontstaan op veel markten hoge toetredingsbarrières door de vereiste zeer hoge R\&D-uitgaven. Als gevolg daarvan vindt er op wereldwijde schaal oligopolievorming plaats. Om de risico's te beperken zoeken de grote ondernemingen toenadering tot de nationale overheden. Door deze ontwikkelingen komt in dit scenario de nadruk te liggen op het Coördinatie-perspectief.

Het European Renaissance scenario gaat er van uit dat de economische achteruitgang van de Verenigde Staten, het inbedden van het 'nieuwe' Duitsland in Europa en het noodzakelijke antwoord op de technologie-wedloop met Japan en de Dynamic Asean Economies het Europese integratieproces zullen bevorderen. Deze verdergaande Europese integratie zorgt er tevens voor 
dat er een actief technologie-, energie- en milieubeleid kan worden gevoerd. Bovendien kan daardoor het functioneren van de Europese goederen- en arbeidsmarkten aanzienlijk verbeteren.

\section{Nationale ontwikkelingen}

Voor Nederland betekent het verdergaande Europese integratieproces dat het monetaire beleid door de Europese Centrale Bank wordt gevoerd en het begrotingsbeleid van de nationale overheden wordt onderworpen aan globale regels die op EG-niveau zijn vastgesteld. Tal van grensoverschrijdende beleidsvraagstukken op het terrein van milieu, energie, infrastructuur, samenwerking met Oost-Europa, defensie, buitenlandse politiek en handelspolitiek zullen in European Renaissance van Den Haag naar Brussel verschuiven. Aan de andere kant zal de besluitvorming en beleidsuitvoering bij vraagstukken op het gebied van arbeidsmarktbeleid, sociale zekerheid, volkshuisvesting en onderwijs, op basis van efficiency-overwegingen, verschuiven naar regionale of lokale overheden en uitvoeringsorganisaties op het gebied van arbeidsvoorziening, sociale zekerheid, onderwijs en gezondheidszorg.

\section{Ontwikkelingen op de arbeidsmarkt}

Binnen het European Renaissance scenario vindt er in de sociale zekerheid een sterke accentverschuiving plaats van inkomensgarantie bij inactiviteit naar een activerend arbeidsmarktbeleid. De overheid schept meer mogelijkheden tot scholing en werkervaring in combinatie met financiële prikkels en dwang na een bepaalde duur van de werkloosheid. Zo zullen mensen onder de dertig jaar die langer dan 6 maanden werkloos zijn, werk, scholing of een werkervaringsplaats moeten accepteren. Werklozen boven de dertig jaar hebben na twee jaar een plicht tot scholing of het accepteren van een werkervaringsplaats. Indien men hier niet aan wil voldoen, wordt men bestraft met een forse vermindering van de uitkering. De overheid zal verder de arbeidsmarktrelevante uitkeringen versoberen en gedeeltelijk ontkoppelen van de contractlonen.

Het CPB doet slechts weinig expliciete uitspraken over de wijze waarop binnen het European Renaissance scenario de bestaande rigiditeiten op de arbeidsmarkt worden aangepakt. Het scenario geeft alleen aan dat:

- werkgevers controleerbare inspanningen gaan doen ter inschakeling van zwakke groepen (etnische minderheden, gedeeltelijk arbeidsongeschikten etc.) in het arbeidsproces;

- de vakbeweging bereid is om bestaande belemmeringen voor de creatie van laagbetaalde lonen in CAO's weg te nemen;

- het begrip passende arbeid aanzienlijk wordt verruimd, voor zowel arbeidsongeschikten als langdurig werklozen.

\section{Ontwikkelingen in de gezondheidszorg}

Het European Renaissance scenario veronderstelt dat er in de gezondheidszorg met succes een stelselwijziging wordt doorgevoerd. De zorgverzekeraars worden deels gebudgetteerd en zijn deels afhankelijk van de door henzelf vastgestelde nominale premies. Er komt een verplichte 
basisverzekering waarin $95 \%$ van de huidige zorgvoorzieningen is opgenomen. Van dit basispakket wordt $85 \%$-punt gefinancierd door middel van inkomensafhankelijke premies, die worden geïnd via de belastingdienst. De overige 10\%-punt wordt gefinancierd uit nominale premies, die door de zorgverzekeraars zelf worden geïnd. De overheid stelt in dit scenario het macro-budget voor het collectief gefinancierde deel van de basisverzekering vast. In het scenario is het zowel voor zorgverzekeraars als voor aanbieders van zorg niet toegestaan om winst te maken. Het huidige vestigingsbeleid voor aanbieders van zorg blijft gehandhaafd.

In samenwerking met de zorgverzekeraars gaat de overheid de inefficiëntie in de zorgsector aanpakken door middel van regelmatig terugkerende uitvoerige vergelijkende onderzoeken naar de medische praktijk van individuele instellingen van intramurale zorg, specialisten en huisartsen. Bovendien gaat de overheid zich steeds nadrukkelijker richten op kwaliteitscontrole, waarbij zij zelf overigens zoveel mogelijk op afstand probeert te blijven. Hoewel het overheidsbeleid er op is gericht om de positie van de zorgverzekeraars te versterken, zal zij de zorgverzekeraars tegelijkertijd goed in de gaten moeten houden. De uitgangsposities van de zorgverzekeraars lopen namelijk sterk uiteen, hetgeen tot uitdrukking komt in hun specifieke deskundigheid, de samenstelling van het verzekerdenbestand, de bedrijfsvoering en de reservepositie. Deze verschillende uitgangsposities van de zorgverzekeraars zijn mogelijk van doorslaggevende invloed op de marktsituatie die uiteindelijk tot stand komt. De overheid moet aan de ene kant ten aanzien van de basisverzekering een goede samenwerking tussen zorgverzekeraars tot stand brengen, terwijl aan de andere kant voor de aanvullende verzekering concurrentie tussen de verzekeraars wenselijk wordt geacht. Ten slotte zal de overheid in dit scenario fors gaan investeren in de technologische ontwikkeling van de extramurale zorg.

Door de in European Renaissance voorgestelde stelselherziening wordt de positie van de zorgverzekeraars versterkt, waardoor zij beter in staat zijn om adequaat tegenspel te bieden aan de zorgaanbieders. Verder zullen door de vereenvoudigde aanbodwetgeving inefficiënties afnemen en zullen de aanbieders van zorg meer ruimte krijgen om zorg op maat aan te bieden.

In dit scenario groeit de intramurale sector uit tot een gespecialiseerde high-tech sector. Veel kleine behandelingen die nu nog in de intramurale zorg plaatsvinden, zullen worden overgenomen door poliklinieken, huisartsen en kleine gezondheidscentra. De specifiek verzorgende functies zullen worden overgenomen door instellingen met een hotelfunctie en de thuiszorg. Dit zal dan ook leiden tot een forse groei van de extramurale sector. Door de in het European Renaissance scenario veronderstelde overheidsinvesteringen in de technologische ontwikkeling van de extramurale zorg zal de intramurale zorg op een aantal gebieden uit de markt worden geprezen, waardoor de efficiëntie en dus de produktiviteit binnen de gezondheidszorg zal stijgen.

In het European Renaissance scenario zal eveneens een goede basis ontstaan voor relatief kleine regionale of lokale gezondheidscentra waarin het aanbod en de financiering van de zorg zijn geïntegreerd. De behoefte aan deze gezondheidscentra komt deels voort uit zorginhoudelijke trends, zoals zorg op maat, een geïntegreerde aanpak van gezondheidsproblemen, de behande- 
ling of verzorging in de woonomgeving, maar komt vooral ook voort uit kostenoverwegingen.

\subsection{De drie scenario's samengevat}

Eén van de belangrijkste factoren die de totale zorgconsumptie bepalen, is de demografische ontwikkeling. Tabel 4.1 geeft daarom een overzicht van enkele belangrijke demografische kengetallen. Daarbij worden de voor de drie scenario's verwachte ontwikkelingen in de omvang en de samenstelling van de Nederlandse bevolking in de periode 1990-2015 bovendien vergeleken met de ontwikkelingen die zich hierin in het verleden hebben voorgedaan.

Tabel 4.1. Enkele demografische kengetallen voor Nederland

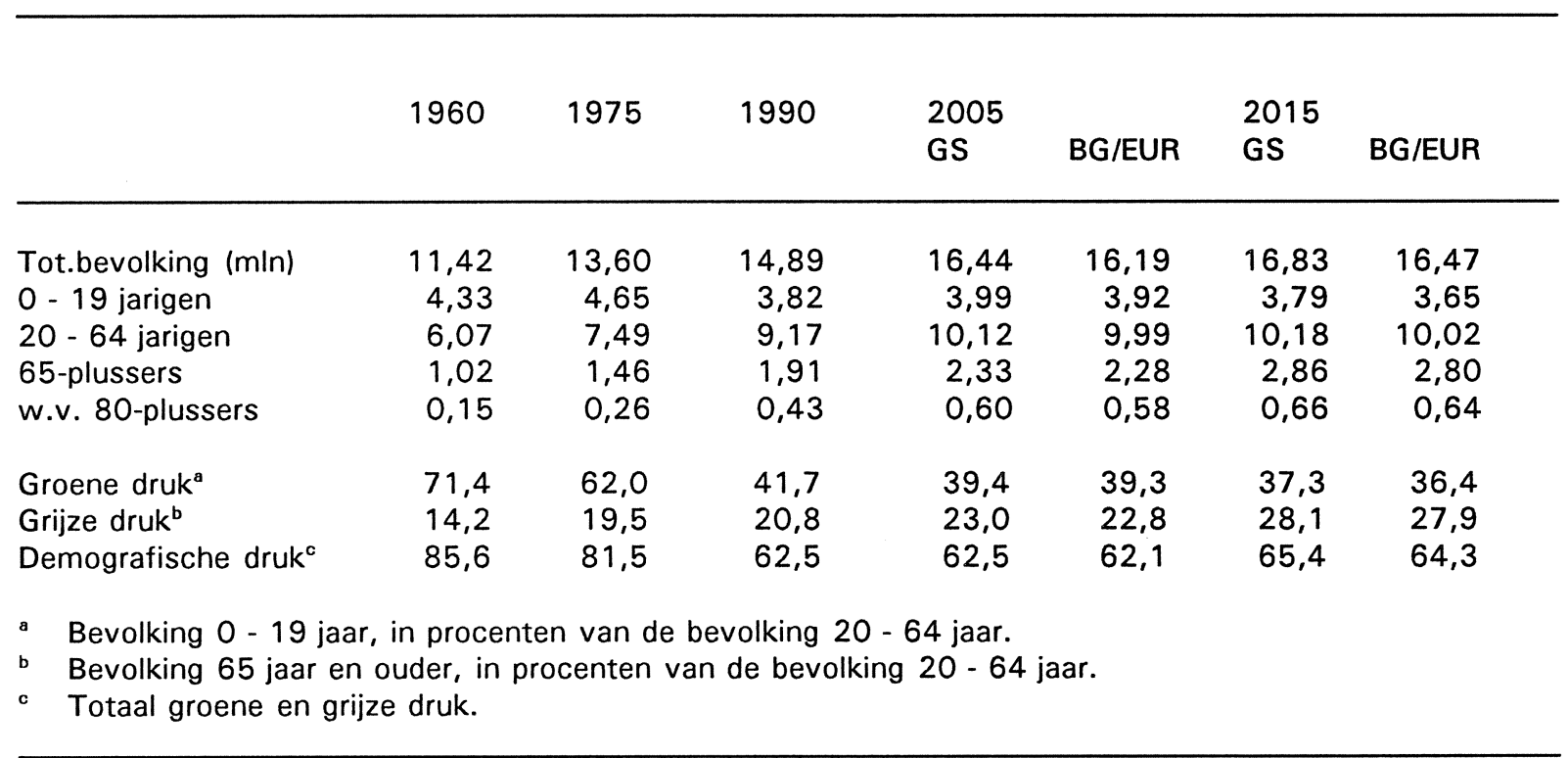

Bron: $\mathrm{CPB}$

De bevolkingsgroei die zich de afgelopen decennia heeft voorgedaan, zal zich slechts in beperkte mate voortzetten. De samenstelling van de bevolking wijzigt echter aanzienlijk. Aangenomen mag worden dat in de komende decennia het aantal ouderen zowel absoluut als relatief gezien verder zal toenemen. Er kan zelfs worden gesproken over een dubbele vergrijzing, doordat onder de ouderen het percentage 80-plussers aanzienlijk zal groeien. Tabel 4.1 laat tevens zien dat de ontgroening in Nederland zich naar verwachting enigszins stabiliseert.

Schema 4.1 geeft een samenvattend overzicht van de belangrijkste veronderstellingen met betrekking tot de ontwikkelingen in de gezondheidszorg voor de drie scenario's. In tabel 4.2 zijn nog enkele andere belangrijke indicatoren voor de drie scenario's op een rijtje gezet. De waarde van het Bruto Binnenlands Produkt (BBP) neemt naar verwachting voor alle scenario's sterk toe. Bij het Global Shift scenario is deze waardestijging echter vooral het gevolg van een forse prijsstijging. Het volume van het BBP neemt slechts toe met gemiddeld 1,5\% tot 2,3\% per jaar. Voor het European Renaissance scenario is dit $2,7 \%$ tot $3,0 \%$, terwijl binnen het Balanced Growth scenario het BBP-volume met gemiddeld maar liefst 3,2\% tot 3,3\% toeneemt. 
Het CPB gaat ervan uit dat de kosten van de zorg ${ }^{20}$ binnen alle scenario's in aanzienlijke mate zullen toenemen. Het grootste deel van deze kostenstijging is het gevolg van zeer forse prijsstijgingen. Deze prijsstijgingen worden veroorzaakt door de stijging van de loonkosten, die noodzakelijk is om de verhoogde werkdruk voor verpleegkundigen te compenseren. In volumina nemen de 'kosten' van de zorg toe met bijna 2\% per jaar in Global Shift en met ongeveer 3\% per jaar in de beide andere scenario's. Per capita komt dit neer op een toename, variërend van jaarlijks gemiddeld $1,0 \%$ in de periode $1991-2005$ in het Global Shift scenario tot 2,9\% in 2006-2015 in Balanced Growth.

Schema 4.1. Enkele belangrijke scenario-veronderstellingen met betrekking tot de ontwikkelingen in de gezondheidszorg

Global Shift

- Tot 2005 vinden er geen beleidswijzigingen plaats.

- De collectieve lastendruk loopt tot 2005 sterk op.

- $\quad$ Er is sprake van een toenemende regulering en hogere solidariteitsheffingen.

- Rond 2005 vindt een abrupte beleidsreactie plaats.

Balanced Growth

- Er wordt een nieuw stelsel voor de gezondheidszorg ingevoerd. In dit stelsel zijn, onder meer in de vorm van eigen bijdragen en eigen risico's, sterke financiële prikkels opgenomen.

- Door de overheid wordt een doeltreffend mededingingsbeleid gevoerd.

- Er is slechts een geringe stijging van de collectieve lastendruk.

European Renaissance

- Het doorvoeren van een stelselwijziging, waarbij wordt uitgegaan van een vrij omvattende basisverzekering, leidt tot een verbetering van de efficiency en de effectiviteit.

- De overheid stelt het macro-budget voor de basisverzekering vast. Dit leidt tot kostenbeheersing in de gezondheidszorg.

- Het aandeel van de gezondheidszorg in de nationale werkgelegenheid en internationaal inkomen blijft toenemen.

De voor dit onderzoek belangrijkste veranderingen betreffen vanzelfsprekend de ontwikkelingen op de arbeidsmarkt. In het Global Shift scenario wordt voor de periode 1991-2005 een geringe afname van de totale werkgelegenheid verwacht. In de zorgsector is er echter sprake van een betrekkelijk grote toename van de werkgelegenheid, zodat ook het aandeel van de zorgsector in de totale werkgelegenheid fors toeneemt. Voor de periode 2006-2015 ziet de situatie er binnen dit scenario echter geheel anders uit. De werkgelegenheidsgroei in de zorgsector neemt iets af, terwijl de totale werkgelegenheid juist gaat toenemen. Hierdoor neemt het werkgelegenheidsaandeel van de zorgsector in deze periode iets af. De arbeidsparticipatie van vrouwen neemt in dit scenario in de periode 1991-2005 niet toe. Na de totale economische crash in het jaar 2005 zal de arbeidsparticipatie van vrouwen met gemiddeld bijna $1 \%$ per jaar stijgen, hetgeen over de periode 2006-2015 neerkomt op een totale stijging van 5\%-punt.

20. Zoals reeds eerder opgemerkt hanteert het CPB een erg brede definitie van de zorgsector door ook de 'Maatschappelijke dienstverlening e.d.' en de sector 'Cultuur sport en recreatie' hierbij te rekenen. 
In het Balanced Growth scenario wordt voor de totale economie een werkgelegenheidstoename van circa $1 \%$ per jaar verwacht. De werkgelegenheidsgroei in de zorgsector is echter met bijna $2,5 \%$ per jaar fors groter. Het aandeel van de zorgsector in de totale werkgelegenheid neemt derhalve aanzienlijk toe. Door de in paragraaf 4.3 genoemde forse sanering van het sociale zekerheidsstelsel zal de arbeidsparticipatie van vrouwen in dit scenario toenemen, zowel door de instroom van nieuwkomers als door herintreders. Aangezien er in de gezondheidszorg voornamelijk vrouwen werkzaam zijn en het verloop uit de sector erg hoog is, zal een toename van de arbeidsparticipatie van vrouwen leiden tot een groei van het arbeidsaanbod in de gezondheidszorg. Hoewel de vraag naar personeel in de toekomst zal blijven toenemen, zorgen produktiviteitsstijging en substitutie in combinatie met de extra instroom van vrouwen met een verzorgende opleiding derhalve voor voldoende tegenwicht. Het CPB acht het dan ook onwaarschijnlijk dat er binnen dit scenario een opwaartse druk op de lonen gaat plaatsvinden.

Tabel 4.2. Enkele kerncijfers voor de drie scenario's (jaarlijkse procentuele mutaties)

\begin{tabular}{llllll}
\hline & \multicolumn{2}{c}{ GS } & \multicolumn{2}{c}{ EUR } \\
Scenario & \multicolumn{2}{c}{ BG } & \multicolumn{2}{c}{ GS }
\end{tabular}

\begin{tabular}{|c|c|c|c|c|c|c|}
\hline \multicolumn{7}{|l|}{$B B P$} \\
\hline Waarde & 7,2 & 5,0 & 7,6 & 5,5 & 6,6 & 5,6 \\
\hline Volume & 3,3 & 3,2 & 1,5 & 2,3 & 2,7 & 3,0 \\
\hline Prijs & 3,8 & 1,8 & 6,0 & 3,1 & 3,8 & 2,5 \\
\hline \multicolumn{7}{|l|}{ Kosten gezondheidszorg } \\
\hline Waarde & 8,1 & 6,6 & 9,4 & 5,3 & 8,0 & 6,7 \\
\hline Volume & 3,0 & 3,1 & 1,7 & 1,8 & 2,8 & 2,9 \\
\hline Prijs & 5,0 & 3,4 & 7,6 & 3,4 & 5,1 & 3,7 \\
\hline Bevolking & 0,6 & 0,2 & 0,7 & 0,2 & 0,6 & 0,2 \\
\hline Zorgvolume per hoofd & 2,4 & 2,9 & 1,0 & 1,6 & 2,2 & 2,7 \\
\hline \multicolumn{7}{|l|}{ Werkgelegenheid } \\
\hline Totaal & 1,0 & 0,9 & $-0,1$ & 1,0 & 0,7 & 0,7 \\
\hline Gezondheidszorg & 2,4 & 2,4 & 1,7 & 0,7 & 2,4 & 2,0 \\
\hline
\end{tabular}

Bron: CPB

Het CPB doet, net als in het Global Shift scenario, geen expliciete uitspraken over de veranderingen die in het European Renaissance scenario op de arbeidsmarkt in de gezondheidszorg zullen plaatsvinden. Uit tabel 4.2 blijkt wel dat in de periode 1991-2005 de groei van de werkgelegenheid in de gezondheidszorg 1,7\%-punt hoger is dan de totale groei van de werkgelegenheid. In de periode 2006-2015 is de groei van de werkgelegenheid in de gezondheidszorg 1,3\%-punt hoger dan de totale werkgelegenheidsgroei. In het European Renaissance scenario neemt de participatie van vrouwen met $14 \%$-punt toe. Dit betekent dat de arbeidsparticipatie van vrouwen 4\%-punt minder stijgt dan in het Balanced Growth scenario, maar $9 \%$ punt meer toeneemt dan in het Global Shift scenario. 


\section{GLOBAL SHIFT}

\subsection{Inleiding}

In dit hoofdstuk zal een beeld worden geschetst van de arbeidsmarktontwikkelingen in de zorgsector in het Global Shift scenario. Daarbij wordt ingegaan op de ontwikkelingen in zowel de onderscheiden deelsectoren als de onderscheiden beroepsgroepen. Achtereenvolgens komen de te verwachten toekomstige stromen op de arbeidsmarkt aan de orde: de uitbreidingsvraag (werkgelegenheidsontwikkeling), de vervangingsvraag, het totaal aantal baanopeningen, de instroom van schoolverlaters en de uit de vraag-aanbod confrontatie voortvloeiende verwachte arbeidsmarktsituatie in het jaar 2005. Eerst wordt een algemene karakterisering van het Global Shift scenario gegeven, toegespitst op de verschillende prognose-elementen. Vervolgens wordt in kwantitatieve zin aangegeven hoe de arbeidsmarkt in de zorgsector zich tot het jaar 2005 volgens Global Shift gaat ontwikkelen.

\section{Uitbreidingsvraag}

In het Global Shift scenario is er tot het jaar 2005 slechts sprake van een jaarlijkse economische groei van 1,5\%. De werkgelegenheidsontwikkeling in ons land zal daardoor geheel stagneren en naar verwachting zelfs inkrimpen met $0,1 \%$ per jaar. Voor de kwartaire dienstverlening wordt desalniettemin nog een toename van het aantal werkenden verwacht van $1,7 \%$.

Zoals reeds is aangegeven in hoofdstuk 4, worden er in dit scenario tot 2005 geen efficiencyverbeteringen in de zorgsector gerealiseerd. Wijzigingen in het stelsel van ziektekostenverzekering komen niet van de grond, vanwege de onderlinge verdeeldheid tussen de aanbieders van zorg, de verzekeraars, patiëntenorganisaties enz. Ook het financieringssysteem in de gezondheidszorg wordt niet of nauwelijks gewijzigd. Dit betekent onder meer dat de medisch specialisten, evenals momenteel het geval is, per verrichting worden betaald. Er worden in het financieringssysteem ook geen prikkels ingebouwd voor een meer doelmatige werkwijze in de zorgsector. Daardoor is er in dit scenario nauwelijks sprake van substitutie van de zorgverlening tussen de diverse deelsectoren.

Dit alles zal leiden tot een forse stijging van de kosten van de gezondheidszorg met maar liefst $9,4 \%$ per jaar (zie tabel 4.2). Een groot deel van deze kostenstijging is het gevolg van de prijsontwikkelingen van medische verrichtingen, medicijnen e.d. Vanwege deze kostenstijgingen zal de overheid het bestaande budgetteringssysteem nog stringenter willen toepassen. De gestelde budgetten worden echter bewust door de zorgaanbieders, onder druk van de publieke opinie, overschreden. De medici laten zich bij (investerings-)beslissingen louter leiden door medische overwegingen, terwijl financiële overwegingen niet of nauwelijks een rol spelen. Daardoor worden meer efficiënte behandelingswijzen en efficiency-verhogende organisatorische vernieuwingen slechts marginaal geïntroduceerd. Dit leidt er toe dat er in het Global Shift scenario vooral in de deelsectoren binnen de intramurale zorgverlening sprake is van een voortgaande technologische ontwikkeling, die weinig bijdraagt aan de verbetering van de produk- 
tiviteit in de zorgverlening.

Dit betekent dat de ontwikkeling van de werkgelegenheid in de zorgsector vooral door de demografische druk wordt bepaald. In de eerste plaats is er sprake van een volume-effect. Mede vanwege de toenemende immigratie van Afrikanen en Oost-Europeanen zal het aantal personen dat een beroep op de zorgverlening doet groter zijn. Bovendien zal als gevolg van de toenemende vergrijzing, de werkgelegenheid in alle onderscheiden zorgsectoren fors toenemen. Dit heeft vanzelfsprekend voornamelijk gevolgen voor de deelsectoren, waar vooral ouderen gebruik van maken. Naast de bejaardenoorden zijn dit de psychiatrische ziekenhuizen en de verpleeghuizen. Pogingen om een groter deel van de intramurale zorgverlening voor ouderen te 'extramuraliseren' stranden door acties van belangengroepen binnen de intramurale zorg.

Niet alleen door de demografische ontwikkeling, maar ook als gevolg van een, mede door de technologische ontwikkelingen gestimuleerde, trendmatige toename van het gebruik van de verschillende voorzieningen in de gezondheidszorg, zal de werkgelegenheid in vrijwel alle deelsectoren toenemen. Deze trendmatige groei wordt mede veroorzaakt doordat er in het bestaande stelsel van de gezondheidszorg voor de burgers nauwelijks financiële prikkels bestaan om tot een efficiënter gebruik van de zorgvoorzieningen over te gaan. Hierdoor zullen de individuele (verzekerings)kosten van de gezondheidszorg stijgen, mede als gevolg van de stijgende 'poolingsbijdragen'.

\section{Vervangingsvraag}

In dit scenario blijft de participatiegraad van de bevolking de komende jaren op een relatief laag niveau. Maatregelen om de arbeidsongeschiktheid en het ziekteverzuim terug te dringen zijn nauwelijks effectief. Niet alleen worden op grote schaal binnen de CAO's aanvullende voorzieningen overeengekomen, maar ook het begrip 'passende arbeid' vindt in de praktijk weinig ingang. Voor de zorgsector betekent dit onder meer dat het personeelsverloop van met name vrouwen in de zorgsector op een hoog niveau blijft liggen, waardoor er een grote (vervangings)behoefte aan schoolverlaters bestaat. In de beroepsgroepen verzorgenden en helpenden wordt een relatief groot deel van de totale vervangingsbehoefte opgevangen door arbeidskrachten die instromen vanuit andere beroepsgroepen buiten de zorgsector of door herintreders. Door de hogere en meer specifieke opleidingseisen voor verpleegkundigen en ziekenverzorgenden, is de instroom in de intramurale zorgverlening van wat oudere arbeidskrachten, aanmerkelijk geringer. Dit wordt nog versterkt door de onregelmatige werktijden die het werken in de beroepen verpleegkundige en ziekenverzorgende voor veel herintreders minder aantrekkelijk maakt. Bovendien is er vooral bij deze beroepen sprake van een hoge doorstroom van jongere arbeidskrachten, die na korte tijd werkzaam te zijn geweest in de zorgsector vanwege de hoge werkdruk en de geringe loopbaanperspectieven uitwijken naar een ander werkveld. Dit alles betekent dat er vooral voor de vier onderscheiden deelsectoren binnen de intramurale zorg een relatief grote vervangingsvraag naar schoolverlaters bestaat. Daarmee samenhangend is met name voor de beroepsgroepen verpleegkundige en ziekenverzorgende de vervangingsvraag naar schoolverlaters relatief hoog. 
Als gevolg van de rigiditeiten in het belastingstelsel en het stelsel van sociale voorzieningen zal vooral voor vrouwen die geen kostwinner zijn, de aantrekkelijkheid van een kleine deeltijdbaan in de zorgsector niet toenemen. Het netto (gezins)inkomen zal immers nauwelijks toenemen door het accepteren van een kleine baan, terwijl aan de andere kant de kosten van bijvoorbeeld kinderopvang wel op het gezinsbudget drukken. Dit maakt dat het aantal herintreders in dit scenario beperkt blijft, waardoor een relatief groot deel van de totale vervangingsbehoefte door schoolverlaters moet worden ingevuld.

\section{Instroom van schoolverlaters}

Bij de studie- en beroepskeuze van jongeren spelen arbeidsmarktoverwegingen in onvoldoende mate een rol. Jongeren laten zich niet leiden door verwachte overschotten of tekorten op de arbeidsmarkt, maar baseren hun studiekeuze, behalve op hun eigen preferenties, louter op de actuele arbeidsmarktsituatie of hun percepties daarvan, waardoor de sterke schommelingen in de instroom van nieuwkomers (de zogenaamde 'varkenscycli') op deze arbeidsmarktsegmenten zullen blijven voortbestaan. Daarbij worden de cycli nog versterkt door de fluctuerende opleidingsbereidheid bij de zorginstellingen met betrekking tot hun inservice-opleidingen. De instroom van jongens op de beroepssegmenten in de zorgsector zal ook klein blijven. Bij de meisjes blijft echter een relatief groot deel voor de zorgberoepen kiezen. Al met al betekent dit dat er, terwijl er macro-economisch sprake is van een aanbodoverschot, op diverse deelmarkten tekorten aan arbeidskrachten blijven bestaan. Maatregelen van Arbeidsvoorziening om bepaalde knelpunten door middel van een preventief arbeidsmarktbeleid te voorkomen, hebben nauwelijks resultaat, mede vanwege de al genoemde rigiditeiten in het sociale zekerheids- en belastingstelsel.

\subsection{Uitbreidingsvraag}

Door de groei en de vergrijzing van de bevolking is er in Global Shift tot het jaar 2005 sprake van een werkgelegenheidsgroei in de zorgsector van gemiddeld 3,2\% per jaar, een groeipercentage dat aanzienlijk hoger ligt dan de jaarlijkse werkgelegenheidsgroei in de kwartaire dienstverlening van $1,7 \%$. Dit betekent dat de al jaren voortgaande trend van een groter beslag van de zorgberoepen op de totale werkgelegenheid in de kwartaire dienstverlening zal aanhouden. Tabel 5.1 laat zien dat in de bejaardenoorden de behoefte aan uitbreiding van het aantal arbeidsplaatsen het grootst is. In de periode 1993-2005 bedraagt de uitbreidingsvraag in deze deelsector maar liefst bijna 40.000 personen, hetgeen overeenkomt met een werkgelegenheidsgroei van ruim $5 \%$ per jaar. Ook in de sectoren psychiatrische ziekenhuizen en verpleeghuizen gaat er van de demografische druk een sterke opwaartse impuls uit op de werkgelegenheidsontwikkeling. De werkgelegenheid in deze sectoren stijgt hierdoor jaarlijks gemiddeld met respectievelijk $5 \%$ en $4,1 \%$.

In de andere deelsectoren binnen de zorg is de groei van het aantal arbeidsplaatsen verhoudingsgewijs minder groot, ofschoon ook in deze sectoren de verwachte jaarlijkse stijging van de werkgelegenheid gemiddeld ongeveer $2 \%$ bedraagt. In absolute termen is de werkgelegenheids- 
groei echter ook in deze sectoren aanzienlijk. Zo bedraagt de werkgelegenheidstoename in de gezinszorg ruim 25.000 personen. In de ziekenhuizen komen er in Global Shift de komende 12 jaar ruim 15.000 arbeidsplaatsen voor verpleegkundig en verzorgend personeel bij. In de sectoren gehandicaptenzorg en het kruiswerk neemt de werkgelegenheid met ruim 5.000 toe.

Tabel 5.1. Uitbreidingsvraag per deelsector scenario Global Shift 1993-2005 (totaal aantal en gemiddelde jaarlijkse groei)

\begin{tabular}{lrc}
\hline Deelsector & aantal & $\%$ \\
\hline Ziekenhuizen & 15.200 & 1,9 \\
Psychiatrische ziekenhuizen & 11.200 & 5,0 \\
Verpleeghuizen & 23.700 & 4,1 \\
Gehandicaptenzorg & 5.800 & 2,4 \\
Gezinszorg & 26.600 & 2,2 \\
Kruiswerk & 5.300 & 2,2 \\
Bejaardenoorden & 38.800 & 5,3 \\
& & 3,2 \\
\hline
\end{tabular}

Bron: ROA

De werkgelegenheidsdruk die op de sector bejaardenoorden ontstaat vindt zijn weerslag in de extra behoefte aan verzorgenden. Ook in de gezinszorg zal een groot deel van de extra zorg door verzorgenden worden uitgeoefend. Als gevolg daarvan zal de uitbreidingsvraag naar verzorgenden de komende jaren erg hoog zijn. In totaal komen er in deze beroepsgroep in de periode 1993-2005 maar liefst 40.000 arbeidsplaatsen bij. Dit komt neer op een jaarlijkse werkgelegenheidstoename van $5,5 \%$. Bijna $70 \%$ van deze totale werkgelegenheidsgroei voor verzorgenden komt voort uit de toenemende zorgbehoefte in de bejaardenoorden.

Tabel 5.2. Uitbreidingsvraag per beroepsgroep scenario Global Shift 1993-2005 (totaal aantal en gemiddelde jaarlijkse groeil

\begin{tabular}{lcc} 
Beroepsgroep & aantal & $\%$ \\
\hline Verpleegkundigen & 38.500 & 2,6 \\
Ziekenverzorgenden & 30.000 & 4,0 \\
Verzorgenden & 40.800 & 5,5 \\
Helpenden & 17.500 & 1,7 \\
Totaal & 126.800 & 3,2 \\
\hline
\end{tabular}

Bron: ROA

De additionele behoefte aan ziekenverzorgenden tot het jaar 2005 bedraagt circa 30.000 personen. Ongeveer twee derde van deze extra werkgelegenheid zal zijn geconcentreerd in de verpleeghuizen waar, zoals gezegd, door het toenemend aantal ouderen een sterk groeiende zorgbehoefte ontstaat. Ook de groeiende zorgvraag in de bejaardenoorden zal voor een deel door ziekenverzorgenden moeten worden opgevangen. 
De werkgelegenheidsontwikkeling voor verpleegkundigen en vooral helpenden blijft met respectievelijk $2,5 \%$ en $1,7 \%$ gemiddeld per jaar iets achter bij het algehele beeld van een sterk groeiende zorgsector. De achterblijvende groei van de werkgelegenheid voor helpenden wordt veroorzaakt doordat deze beroepsgroep zowel in de gezinszorg als in de bejaardenoorden terrein verliest. De relatief lagere werkgelegenheidsgroei voor verpleegkundigen hangt voornamelijk samen met de, in verhouding tot de andere zorgsectoren, lagere werkgelegenheidsgroei in de ziekenhuizen. Ruim een derde van de totale uitbreidingsvraag naar verpleegkundigen is afkomstig van deze sector. De extra werkgelegenheid in de bejaardenoorden komt slechts voor een zeer beperkt deel bij de verpleegkundigen terecht. Wel leidt de fors toenemende zorgbehoefte in de psychiatrische ziekenhuizen er toe dat er in deze sector ook een sterke behoefte aan extra verpleegkundigen zal ontstaan. In de periode 1993-2005 zal de werkgelegenheid voor verpleegkundigen in deze sector in totaal met maar liefst $80 \%$ toenemen.

\subsection{Vervangingsvraag}

Doordat in Global Shift de participatie van vrouwen op de arbeidsmarkt in het algemeen laag blijft, zal de uitstroom van werkenden uit de zorgsector op een hoog niveau blijven liggen. Derhalve is er sprake van een vrij grote vervangingsvraag naar schoolverlaters in de zorg. De vervangingsbehoefte bedraagt circa $4 \%$ gemiddeld per jaar. Bij dit cijfer is reeds rekening gehouden met de verwachte instroom van herintreders en degenen die eerst een beroep buiten de zorgsector hebben uitgeoefend, zodat de hier gepresenteerde vervangingsvraag, alsmede de in de vorige paragraaf gepresenteerde uitbreidingsvraag volledig door schoolverlaters zou moeten worden vervuld.

Tabel 5.3. Vervangingsvraag naar schoolverlaters per deelsector scenario Global Shift 1993-2005 (totaal aantal en gemiddeld jaarlijks percentage)

\begin{tabular}{lrc} 
Deelsector & aantal & $\%$ \\
\hline Ziekenhuizen & 44.300 & 4,8 \\
Psychiatrische ziekenhuizen & 9.700 & 4,5 \\
Verpleeghuizen & 27.900 & 4,7 \\
Gehandicaptenzorg & 11.700 & 4,3 \\
Gezinszorg & 41.600 & 3,2 \\
Kruiswerk & 6.200 & 2,5 \\
Bejaardenoorden & 23.100 & 3,5 \\
Totaal & 164.400 & 3,9 \\
\hline
\end{tabular}

Bron: ROA

Uit tabel 5.3 blijkt dat vooral in de intramurale zorgverlening de behoefte aan schoolverlaters, vanwege de vervanging van de uitstromende arbeidskrachten groot is. In totaal bedraagt de vervangingsvraag in de intramurale zorg ruim 90.000 personen, hetgeen overeenkomt met een gemiddeld jaarlijks percentage van circa 4,5. Ongeveer de helft van deze vervangingsbehoefte 
doet zich voor in de ziekenhuizen. In deze sector zullen ongeveer in totaal 45.000 bestaande arbeidsplaatsen opnieuw door schoolverlaters moeten worden ingevuld, dat wil zeggen jaarlijks gemiddeld $4,8 \%$.

In de drie onderscheiden deelsectoren binnen de extramurale zorg is de vervangingsvraag naar schoolverlaters verhoudingsgewijs lager. Dit heeft vooral te maken met het feit dat in deze sectoren de instroom van niet-schoolverlaters, zoals herintredende vrouwen en degenen die eerst enkele jaren een ander beroep hebben uitgeoefend, relatief groot is. Deze instroom van wat oudere arbeidskrachten is vooral bij de helpenden en de verzorgenden belangrijk, mede als gevolg van de lagere opleidingsvereisten voor deze beroepsgroepen. Tabel 5.4 geeft een overzicht van de totale vervangingsvraag naar schoolverlaters in de periode 1993-2005, verbijzonderd naar beroepsgroep.

Tabel 5.4. Vervangingsvraag naar schoolverlaters per beroepsgroep scenario Global Shift 1993-2005 (totaal aantal en gemiddeld jaarlijks percentage)

\begin{tabular}{lcc} 
Beroepsgroep & aantal & $\%$ \\
\hline Verpleegkundigen & 73.900 & 4,5 \\
Ziekenverzorgenden & 35.300 & 4,6 \\
Verzorgenden & 16.900 & 2,7 \\
Helpenden & 38.300 & 3,4 \\
Totaal & 164.400 & 3,9 \\
\hline
\end{tabular}

Bron: ROA

De vervangingsvraag naar zowel verpleegkundigen als ziekenverzorgenden is ongeveer $4,5 \%$ gemiddeld per jaar. Voor de verpleegkundigen komt dit neer op een totale vervangingsbehoefte aan schoolverlaters van bijna 75.000 in de periode 1993-2005. De vervangingsvraag naar ziekenverzorgenden bedraagt in deze periode ongeveer 35.000. De vervangingsbehoefte aan verzorgenden is met 17.000 personen, ofwel $2,7 \%$ gemiddeld per jaar duidelijk lager. Bij de helpenden is de uitstroom van arbeidskrachten groter dan bij de verzorgenden. De vervangingsbehoefte aan schoolverlaters is voor deze beroepsgroep jaarlijks $3,4 \%$.

\subsection{Baanopeningen}

De uitbreidingsvraag en de vervangingsvraag vormen samen het totaal aantal baanopeningen, ofwel de totale behoefte aan schoolverlaters in de toekomstige periode. In tabel $\mathbf{5 . 5}$ wordt per deelsector aangegeven hoe groot het aantal baanopeningen tot 2005 zal zijn. Daarbij wordt tevens weergegeven welk deel van de totale vraag naar schoolverlaters het gevolg is van de werkgelegenheidsgroei en welk deel samenhangt met de vervangingsbehoefte.

Het merendeel van het totaal aantal toekomstige baanopeningen wordt veroorzaakt door de 
vervangingsbehoefte. Van de totale behoefte aan schoolverlaters van bijna 300.000 personen hangt $56 \%$ samen met de vervangingsvraag. In de sector ziekenhuizen is zelfs drie kwart van de ongeveer 60.000 baanopeningen het gevolg van de vervangingsbehoefte. Ook in de gehandicaptenzorg is een relatief groot deel van de totale vraag een gevolg van de vervangingsvraag.

De tabel laat verder zien dat in de sterk groeiende sectoren psychiatrische ziekenhuizen en bejaardenoorden de totale vraag voor meer dan de helft samenhangt met de uitbreidingsvraag. In de laatstgenoemde sector is de totale behoefte aan schoolverlaters tot 2005 bijna 62.000 personen. In de gezinszorg is de totale vraag zelfs nog groter. Ruim 68.000 schoolverlaters zijn in deze sector nodig om enerzijds de toenemende zorgbehoefte op te vangen en anderzijds de uitstroom van werkenden te compenseren.

Tabel 5.5. Totaal aantal baanopeningen en procentuele verdeling over uitbreidingsvraag en vervangingsvraag per deelsector scenario Global Shift 1993-2005

\begin{tabular}{lccc}
\hline Deelsector & aantal & $\begin{array}{c}\text { uitbreidingsvraag } \\
\%\end{array}$ & $\begin{array}{c}\text { vervangingsvraag } \\
\%\end{array}$ \\
\hline & & 26 & 74 \\
Ziekenhuizen & 59.500 & 54 & 46 \\
Psychiatrische ziekenhuizen & 20.900 & 46 & 54 \\
Verpleeghuizen & 51.600 & 34 & 68 \\
Gehandicaptenzorg & 17.100 & 39 & 61 \\
Gezinszorg & 68.200 & 46 & 54 \\
Kruiswerk & 11.500 & 63 & 37 \\
Bejaardenoorden & 61.900 & 44 & 56 \\
Totaal & 291.200 & & \\
\hline
\end{tabular}

Bron: ROA

Tabel 5.6 geeft vervolgens het in het Global Shift scenario verwachte aantal baanopeningen, verbijzonderd naar beroepsgroep. Van het totaal aantal baanopeningen zijn er ongeveer $40 \%$ voor verpleegkundigen. Daarvan is ongeveer een derde vanwege de werkgelegenheidsgroei en twee derde vanwege de vervangingsbehoefte. De totale vraag naar ziekenverzorgenden bedraagt ongeveer 65.000 personen. Circa twee derde deel daarvan is geconcentreerd in de sector verpleeghuizen.

De vervangingsbehoefte naar schoolverlaters met een opleiding tot verzorgende is relatief hoog. Dit hangt vooral samen met de grote werkgelegenheidsgroei in de sector bejaardenoorden en de gezinszorg. Dit maakt dat maar liefst $70 \%$ van de baanopeningen voor verzorgenden het gevolg is van de positieve werkgelegenheidsontwikkeling. Bij de helpenden wordt daarentegen slechts $30 \%$ van de totale vraag veroorzaakt door de uitbreidingsvraag. Zowel in de gezinszorg als in de bejaardenoorden blijft de werkgelegenheidsgroei voor helpenden achter bij de sectorale ontwikkelingen. 
Tabel 5.6. Totaal aantal baanopeningen en procentuele verdeling over uitbreidingsvraag en vervangingsvraag per beroepsgroep scenario Global Shift 1993-2005

\begin{tabular}{lccc}
\hline Beroepsgroep & aantal & $\begin{array}{c}\text { uitbreidingsvraag } \\
\%\end{array}$ & $\begin{array}{c}\text { vervangingsvraag } \\
\%\end{array}$ \\
\hline Verpleegkundigen & 112.400 & 34 & 66 \\
Ziekenverzorgenden & 65.200 & 46 & 54 \\
Verzorgenden & 57.800 & 71 & 29 \\
Helpenden & 55.700 & 30 & 70 \\
Totaal & 291.200 & 44 & 56 \\
\hline
\end{tabular}

Bron: ROA

In tabel 5.7 wordt het aantal in Global Shift verwachte baanopeningen verbijzonderd naar zowel deelsector als beroepsgroep. Van alle baanopeningen voor verpleegkundigen heeft de helft betrekking op de sector ziekenhuizen. De psychiatrische ziekenhuizen en de gehandicaptenzorg vertegenwoordigen beide ongeveer $15 \%$ van het totaal aantal baanopeningen voor verpleegkundigen. Voor de ziekenverzorgenden is de sector verpleeghuizen het belangrijkste. Bijna drie kwart van de baanopeningen voor ziekenverzorgenden doet zich in deze sector voor. Daarnaast heeft een aanzienlijk deel van de baanopeningen voor deze beroepsgroep betrekking op de bejaardenoorden.

Tabel 5.7. Aantal baanopeningen verbijzonderd naar deelsector en beroepsgroep scenario Global Shift 1993-2005

\begin{tabular}{lrrrr}
\hline Deelsector & verpleeg- & $\begin{array}{l}\text { Beroepsgroep } \\
\text { zieken- } \\
\text { verzorgenden }\end{array}$ & verzorgenden & helpenden \\
\hline Ziekenhuizen & 56.500 & 3.000 & - & - \\
Psychiatrische ziekenhuizen & 17.800 & 3.100 & - & - \\
Verpleeghuizen & 9.800 & 41.800 & - & - \\
Gehandicaptenzorg & 16.900 & 600 & - & - \\
Gezinszorg & 5.900 & 2.700 & 2.900 & - \\
Kruiswerk & 5.500 & 14.000 & 35.900 & 6.500 \\
Bejaardenoorden & & & - & - \\
\hline
\end{tabular}

Bron: ROA

Van de in totaal bijna 60.000 baanopeningen voor verzorgenden heeft meer dan $60 \%$ betrekking op de vraag naar nieuwkomers in de sector bejaardenoorden. Ruim $30 \%$ van de baanopeningen heeft betrekking op de gezinszorg. Deze sector heeft de grootste behoefte aan schoolverlaters voor het beroep van helpenden. Maar liefst bijna $90 \%$ van alle baanopeningen voor helpenden vloeit voort uit de vraag naar schoolverlaters in deze sector. 


\subsection{Instroom van schoolverlaters}

Tegenover de totale behoefte aan schoolverlaters in de periode 1993-2005 als gevolg van de verwachte werkgelegenheidsgroei en de vervangingsvraag, staat de totale arbeidsmarktinstroom die verwacht mag worden vanuit de opleidingen die zijn gericht op de vier beroepsgroepen in de zorgsectoren. In tabel 5.8 staat aangegeven hoe groot het nieuwe aanbod van schoolverlaters in Global Shift zal zijn.

Tabel 5.8. Instroom van schoolverlaters per beroepsgroep scenario Global Shift 1993-2005 (totaal aantal en gemiddeld jaarlijks percentage)

\begin{tabular}{lrc} 
Beroepsgroep & aantal & $\%$ \\
\hline Verpleegkundigen & 74.800 & 4,5 \\
Ziekenverzorgenden & 36.700 & 4,7 \\
Verzorgenden & 40.600 & 5,5 \\
Helpenden & 8.000 & 0,8 \\
Totaal & 160.100 & 3,8 \\
\hline
\end{tabular}

Bron: ROA

Van het totaal aantal schoolverlaters dat de komende 12 jaar op de arbeidsmarkt zal instromen, bieden er zich in Global Shift ruim 160.000 aan in de zorgsector. Dit is ongeveer $7 \%$ van de totale arbeidsmarktinstroom in die periode. lets minder dan de helft van dit nieuwe aanbod zal bestaan uit verpleegkundigen. Relatief gezien bedraagt het aanbod van schoolverlaters jaarlijks ongeveer $4,5 \%$ van de werkgelegenheid voor deze beroepsgroep. Ook voor de ziekenverzorgenden wordt een dergelijk instroompercentage van schoolverlaters verwacht. Het percentage schoolverlaters dat met een opleiding tot verzorgende op de markt gaat komen is met jaarlijks gemiddeld $5,5 \%$ iets groter.

Een opvallend lage instroom van schoolverlaters wordt verwacht voor de beroepsgroep helpenden. Volgens deze 'ex-ante raming' komen er circa 8.000 schoolverlaters op de markt. Daarbij moet wel worden opgemerkt dat voor de instroom voor deze beroepsgroep, vanwege de minder stringente opleidingseisen, eveneens kan worden geput uit een groot reservoir van verzorgend opgeleiden op VBO- of MBO-K-niveau. Gezien de in het Global Shift scenario verwachte overschotten voor deze opleidingscategorieën is een additionele instroom, eventueel na extra bijscholing, naar de beroepsgroep helpenden niet onwaarschijnlijk.

\subsection{Toekomstige arbeidsmarktsituatie}

De confrontatie van de toekomstige vraag naar en het toekomstig aanbod van schoolverlaters geeft een inzicht in de toekomstige kwantitatieve verhoudingen op de arbeidsmarkt voor de verschillende zorgberoepen. Tegen het algehele beeld van Global Shift in, waarbij er sprake is 
van een grote werkloosheid op alle niveaus, krijgt de zorgsector opvallend genoeg te maken met enorme problemen in de personeelsvoorziening.

De vraag-aanbod-confrontatie in tabel 5.9 laat zien dat het tekort aan helpenden zowel in absolute als in relatieve zin het grootst is. Zoals echter reeds in paragraaf 5.5 is opgemerkt, zullen er voor deze beroepsgroep waarschijnlijk geen grote recruteringsproblemen optreden, vanwege de hoge werkloosheid onder lager opgeleiden. Aangenomen mag worden dat vanuit deze groep, mogelijk na aanvullende scholing, voldoende helpenden kunnen worden geworven. Dit temeer daar een deel van het werk als gevolg van deze ontwikkelingen waarschijnlijk zal verschuiven naar werkenden op het laagste deskundigheidsniveau (alpha-hulpen). Bovendien zullen de reeds werkende helpenden mogelijk enige uren per week extra gaan werken, waardoor reeds aan een deel van de vraag kan worden voldaan.

Tabel 5.9. Aanbodoverschot of -tekort per beroepsgroep scenario Global Shift in 2005 (totaal aantal en relatief ten opzichte van de verwachte vraag in 2005)

\begin{tabular}{|c|c|c|}
\hline Beroepsgroep & aantal & $\%$ \\
\hline Verpleegkundigen & -37.600 & $-26,0$ \\
\hline Ziekenverzorgenden & -28.600 & $-35,8$ \\
\hline Verzorgenden & -17.200 & $-20,1$ \\
\hline Helpenden ${ }^{a}$ & -47.700 & $-49,7$ \\
\hline Totaal & -131.100 & $-32,2$ \\
\hline
\end{tabular}

a Vanwege de verwachte ruime arbeidsmarkt voor VBO-opgeleiden in de verzorgende richting in het algemeen, zal dit tekort feitelijk niet of nauwelijks optreden.

Bron: ROA

In het Global Shift scenario zullen er wel omvangrijke tekorten aan vooral ziekenverzorgenden ontstaan. Deze tekorten zullen zich met name in de verpleeghuizen en in mindere mate in de bejaardenoorden manifesteren. Door het toenemend aantal ouderen is er in deze sectoren een sterke groei van de zorgbehoefte. Het totale tekort kan oplopen tot maar liefst bijna $\mathbf{3 0 . 0 0 0}$ personen, hetgeen overeenkomt met circa $35 \%$ van de totale verwachte vraag naar personeel in 2005.

Het totale tekort aan verpleegkundigen bedraagt in 2005 zelfs bijna 40.000 personen. Dit betekent dat ruim een kwart van het totaal aantal arbeidsplaatsen in 2005 niet zou kunnen worden vervuld. Deze knelpunten gaan zich vooral in de intramurale zorgverlening voordoen. Daarbinnen zijn de tekorten in de psychiatrische ziekenhuizen naar verwachting verhoudingsgewijs het grootst. In de gehandicaptenzorg zal daarentegen het tekort aan verpleegkundigen relatief lager zijn. Het kruiswerk krijgt nauwelijks met personeelstekorten aan verpleegkundigen te maken. De instroom vanuit de HBO-opleidingen in deze sector zal ruim voldoende zijn om aan de vraag naar schoolverlaters te voldoen. 
Het tekort aan verzorgenden maakt dat aan de grotere zorgbehoefte in de gezinszorg niet volledig kan worden voldaan. Een deel van de zorgtaken in deze sector kan in feite niet worden uitgevoerd. Verder hebben ook de bejaardenoorden, naast een duidelijk tekort aan ziekenverzorgenden, te kampen met een aanbodtekort van verzorgenden.

De tekorten aan verpleegkundigen en ziekenverzorgenden zullen enerzijds leiden tot werkdrukverhoging en een toenemende arbeidsonrust in de diverse zorgsectoren. Anderzijds zal er een opwaartse druk op de lonen van deze beroepsgroepen ontstaan, waardoor de door de overheid vastgestelde budgetten telkens worden overschreden en de wachtrijen voor de verschillende zorgsectoren maatschappelijk onaanvaardbare proporties zullen aannemen.

Zoals reeds is opgemerkt, treden de tekorten aan personeel in de zorgsector op bij een in zijn algemeenheid zeer ruime arbeidsmarkt. Zoals ook in de jaren tachtig is gebleken, zijn dergelijke aanbodtekorten ondanks de in het algemeen hoge werkloosheid bij de beroepsgroepen in de zorgsector, waarvoor strikte opleidingsvereisten bestaan, doorgaans moeilijk op basis van een korte-termijn-beleid te bestrijden. Onder meer door de remmende werking van het belastingstelsel op de arbeidsmarktparticipatie van niet-kostwinners kan men er niet in slagen om voldoende personeel voor de zorgsectoren te krijgen. Daarnaast is er sprake van een laag blijvende arbeidsmarktparticipatie doordat maatregelen om het aantal arbeidsongeschikten en het ziekteverzuim terug te dringen in Global Shift niet goed van de grond komen. Ook de Arbeidsvoorzieningsorganisatie lukt het niet om voldoende personeel voor de bestaande vacatures te recruteren, vooral omdat er voor (om- of bij-)scholing voor beroepen in de zorgsector onvoldoende animo bestaat, vanwege het slechte imago van het werk in deze sector.

De enorme onevenwichtigheidsproblemen in de zorgsector leiden ertoe dat er rond 2005 een abrupte beleidsreactie plaatsvindt. Binnen een tijdsbestek van enkele jaren wordt het stelsel van de gezondheidszorg gereorganiseerd. Er zullen in versneld tempo eigen bijdragen en eigen risico's worden ingevoerd. Verder worden de premies voor een groot deel nominaal geheven, hetgeen onomstotelijk pijnlijke consequenties heeft voor de koopkrachtontwikkeling.

Deze beleidswijziging zorgt ervoor dat na 2005 de collectieve druk van de gezondheidszorg afneemt. De prijsstijgingen die, zoals is opgemerkt, tot 2005 omvangrijk zijn, blijven voortaan beperkt. De werkgelegenheid zal na 2005 minder sterk groeien en zelfs achterblijven bij de macro-economische ontwikkeling. 


\section{BALANCED GROWTH}

\subsection{Inleiding}

In dit hoofdstuk zal een beeld worden geschetst van de arbeidsmarktontwikkelingen voor de zorgsector, zoals die verwacht kunnen worden binnen het Balanced Growth scenario. Evenals in het voorgaande hoofdstuk zal daarbij achtereenvolgens worden ingegaan op de uitbreidingsvraag, de vervangingsvraag, het daaruit resulterend totaal aantal baanopeningen, de verwachte instroom van schoolverlaters en de uit de vraag- en aanbodontwikkelingen resulterende verwachte arbeidsmarktsituatie voor het jaar 2005. Daarbij zal eerst, in aansluiting op het in hoofdstuk 4 in algemene termen beschreven karakter van het Balanced Growth scenario, nader worden ingegaan op de ontwikkelingen die in dit scenario binnen de zorgsector mogen worden verwacht en daarmee meer specifiek van invloed zullen zijn op de arbeidsmarktontwikkelingen in de verschillende deelsectoren van de gezondheidszorg. Vervolgens zal in kwantitatieve termen een beeld worden geschetst van de verschillende prognose-onderdelen. Ten slotte zal de toekomstige arbeidsmarktsituatie in de zorgsector in het jaar 2005 volgens het Balanced Growth scenario worden belicht.

\section{Uitbreidingsvraag}

Zoals in hoofdstuk 4 reeds werd aangegeven, is er bij het Balanced Growth scenario sprake van een relatief hoge economische groei van $3,3 \%$ per jaar. Mede hierdoor is de werkgelegenheidstoename in dit scenario het grootst. De positieve ontwikkeling die de Nederlandse economie doormaakt, vergroot ook de financiële ruimte voor de kwartaire dienstverlening, waarvoor binnen dit scenario een bovengemiddelde werkgelegenheidstoename van $2,4 \%$ per jaar wordt verwacht. De toenemende financiële ruimte maakt het tevens mogelijk de wachtlijsten in de zorgsector te verkorten.

Een belangrijke veronderstelling binnen dit scenario is dat een ingrijpende stelselherziening in de gezondheidszorg zal worden doorgevoerd, waarbij $85 \%$ van gezondheidszorgvoorzieningen in een basispakket wordt ondergebracht dat voor bijna drie kwart gefinancierd wordt uit inkomensafhankelijke premies, terwijl bijna een kwart van de kosten wordt opgebracht via nominale premies en het resterende deel wordt betaald vanuit eigen bijdragen en eigen risico's.

In het Balanced Growth scenario is er sprake van een snelle technologische ontwikkeling in zowel de intramurale als de extramurale sector, mede als gevolg van een sterke concurrentie tussen de verschillende aanbieders van zorg. Dit zal leiden tot aanzienlijke produktiviteitsstijgingen. De technologische ontwikkelingen zullen ook van grote invloed zijn op het werkgelegenheidsaandeel van de verplegende en verzorgende beroepen binnen de gezondheidszorg. Bovendien zal het leiden tot werkgelegenheidsverschuivingen tussen de verschillende deelsectoren. De binnen het huidige budgetteringssysteem bestaande belemmeringen voor de diffusie van nieuwe technologieën, zoals endoscopische chirurgie (zie Go, Schol en Gouma, 1993) worden weggenomen door het creëren van een adequate incentivestructuur. Dirksen, Ament, Go en 
Hupkens van der Elst (1994) geven aan dat verschuivingen van traditionele operaties naar endoscopische operaties tot een aanzienlijke verlaging van de gemiddelde ligduur van patiënten kunnen leiden. Zo is er bijvoorbeeld bij een endoscopische galblaasoperatie nog slechts sprake van een gemiddelde ligduur van 3,4 dagen, terwijl patiënten bij een traditionele operatie gemiddeld 10 dagen in het ziekenhuis liggen. Daar staat tegenover dat de kosten van de operatie zelf veel hoger liggen. Per saldo zijn de totale ziekenhuiskosten voor endoscopische en traditionele galblaasoperaties vrijwel gelijk. Ook een verder gaande diffusie van diagnostische laparoscopie kan leiden tot kortere ligduren van patiënten in ziekenhuizen, doordat veel sneller een adequate diagnose gesteld kan worden. Door met een laporoscoop de juiste diagnose te stellen bij een vermeende blindedarmontsteking kan enerzijds de gebruikelijke observatieperiode alvorens tot een operatie wordt overgegaan worden vermeden, terwijl anderzijds $10-15 \%$ van de operaties die achteraf niet nodig blijken te zijn, niet hoeven te worden verricht (zie Go en Van Erp, 1993).

Het op grote schaal invoeren van dergelijke technologieën zal er toe kunnen leiden dat de wachtrijen in de ziekenhuissector in belangrijke mate zullen afnemen. Afgezien van een eventuele toename van de gebruiksintensiteit voor de ziekenhuissector impliceert de diffusie van dergelijke technologieën echter een daling van het totaal aantal verpleegdagen in deze sector. Wel neemt de verpleegintensiteit per patiënt enigszins toe doordat voor iedere patiënt de relatief arbeidsintensieve 'turnover'-activiteiten (opname en ontslag) gehandhaafd blijven.

Al met al leidt de diffusie van de bovengenoemde nieuwe technologieën, vanwege de daling van het aantal ligdagen per patiënt en de kostenverschuiving in de richting van de operatiekosten, tot een daling van het werkgelegenheidsaandeel van verpleegkundigen en ziekenverzorgenden in de ziekenhuissector. Daardoor neemt ook het aandeel van de ziekenhuissector in de totale werkgelegenheid van deze beroepsgroepen af. Door de toegenomen intensiteit van de vereiste verpleging neemt het werkgelegenheidsaandeel van verpleegkundigen binnen de ziekenhuissector iets toe ten opzichte van dat van de ziekenverzorgenden.

De diffusie van endoscopische chirurgie heeft daarnaast gevolgen voor de zorgvraag in de wijkverpleging, de gezinszorg en de bejaardenoorden, vanwege de veel snellere hersteltijd na het ondergaan van een dergelijke operatie. Terwijl men bij een traditionele (galblaas)operatie gemiddeld pas 39 dagen na ontslag uit het ziekenhuis het huishoudelijk werk weer kan hervatten, is dit bij een endoscopische operatie reeds na 13 dagen het geval (Dirksen, Ament, Go en Hupkens van der Elst, 1994). Als gevolg daarvan zal de werkgelegenheid voor verzorgenden en helpenden in deze extramurale sectoren eveneens afnemen.

Bovendien zal als gevolg van de invoering van een systeem van 'managed care' een aanmerkelijke efficiency-verbetering tot stand worden gebracht. Managed care is gebaseerd op een informatiesysteem dat het mogelijk maakt het gehele zorgproces te kunnen volgen en indien nodig te kunnen bijsturen (zie Mantel, 1993). Daarbij gaat het om controleerbare afspraken voor opname, nut en noodzaak van diagnostisch onderzoek en medische handelingen die bij een patiënt worden verricht en een algehele evaluatie van de opname. In de ziekenhuissector zou 
het toepassen van managed care tot een afname van de gemiddelde ligduur van patiënten kunnen leiden van in totaal 9,5\% (zie Johnsson, 1991). Ook in de andere intramurale zorgsectoren biedt de invoering van managed care efficiency-voordelen. In de psychiatrische ziekenhuizen, verpleeghuizen en gehandicaptenzorg kan managed care vooral ook de vorm aannemen van 'case management', waarbij één persoon alle zorg rond een bepaalde patiënt coördineert, waardoor dubbel onderzoek of behandelingen kunnen worden voorkomen. De efficiency-winst die met managed care en case management geboekt kan worden zal al met al een drukkend effect hebben op de werkgelegenheidsgroei in de intramurale zorgsectoren.

Daarnaast zullen efficiency-overwegingen leiden tot substitutieprocessen van relatief dure zorgvormen naar goedkopere vormen van zorg. Doordat de aanspraken van verzekerden op zorg in functionele termen worden omschreven (zie ook Van der Zwan, Van Dijk en Borst-Eilers, 1993) en niet meer aan bepaalde voorzieningen zijn gekoppeld, zal een deel van de huidige verpleeghuiszorg niet langer in een verpleeghuis plaats vinden, maar worden aangeboden in bejaardenoorden en vooral ook in de thuissituatie. Door de afname van de wachtlijsten voor de verpleeghuizen zal er ook een, zij het vrij geringe, verschuiving plaatsvinden van de zorgverlening in ziekenhuizen naar de verpleeghuizen. De incentives voor een verhoogde efficiency leiden er verder toe dat een deel van de taken die eerst door de ziekenhuizen werden verricht worden overgeheveld naar de gezinszorg en het kruiswerk (Mantel, 1993). Vanuit de gehandicaptenzorg en de bejaardenoorden zal uit efficiency-overwegingen een deel van de zorgtaken worden overgeheveld naar de gezinszorg en de wijkverpleging.

Een deel van de gezinszorg valt in het nieuwe stelsel van de gezondheidszorg buiten het basispakket, terwijl er bovendien sprake is van aanzienlijk hogere eigen bijdragen in de gezinszorg en het kruiswerk. Dit zal een remmende werking hebben op de groei van deze deelsectoren. Ook zullen de gevraagde eigen bijdragen een sterk remmend effect hebben op de groei van de sector bejaardenoorden. Bejaardenoorden zullen worden omgevormd tot 'woon-zorg-complexen'. Een deel van ieder bejaardenoord zal dan worden ingericht als een soort verpleeghuis voor geriatrische patiënten, terwijl de andere delen van de instelling bestaan uit zelfstandige en niet-zelfstandige wooneenheden, waarbij de bewoners gebruik kunnen maken van gemeenschappelijke dienstverlening voor huishoudelijke, verzorgende of verpleegkundige hulp.

Ten slotte is er nog sprake van een geringe groei van het aantal werkzame personen in de zorgsector als gevolg van de toenemende mate waarin in deeltijd gewerkt wordt, mede als gevolg van de door het CPB veronderstelde introductie van een gegarandeerd basisinkomen.

\section{Vervangingsvraag}

De te verwachten vervangingsbehoefte wijkt in het Balanced Growth scenario aanzienlijk af van de vervangingsvraag in het Global Shift scenario. In de eerste plaats leidt de hogere participatie tot een aanzienlijk geringer personeelsverloop onder gehuwde vrouwen. Deze toename van de arbeidsmarktparticipatie is deels het gevolg van het afnemend aantal arbeidskrachten dat arbeidsongeschikt wordt, enerzijds vanwege de betere arbeidsomstandigheden in de zorgsector 
en anderzijds vanwege het gevoerde reïntegratiebeleid. Bovendien zal het verloop afnemen als gevolg van de meer marktconforme salariëring en secundaire arbeidsvoorwaarden (waaronder de werkdruk) in de zorgberoepen dan in het Global Shift scenario het geval is. Bovendien hebben de zorgberoepen daardoor een sterkere aantrekkingskracht op degenen die nu geen betaald werk verrichten. Daardoor neemt het aantal herintreders toe. Dit proces wordt nog versterkt doordat fiscale belemmeringen voor het accepteren van deeltijdbanen uit de weg worden geruimd.

Daar staat tegenover dat de intra- en intersectorale mobiliteit binnen de zorgsector zal toenemen, mede als gevolg van de meer evenwichtige situatie op de arbeidsmarkt. Deze grotere mobiliteitsmogelijkheden vergroten overigens de aantrekkelijkheid van de verpleegkundige en verzorgende beroepen. Als gevolg daarvan zal ook de vervangingsvraag die het gevolg is van de hoge doorstroom van jongere arbeidskrachten naar beroepen buiten de zorgsector vooral bij de verpleegkundigen en ziekenverzorgenden aanzienlijk verminderen.

\section{Instroom van schoolverlaters}

De betere werking van de arbeidsmarkt betekent ook dat jongeren bij hun studie- en beroepskeuze beter rekening kunnen houden met de kansen op werk in de verschillende werkterreinen. Dit maakt het mogelijk om in voldoende mate nieuwkomers te recruteren voor de verpleegkundige en verzorgende beroepen. De marktconforme salariëring en secundaire arbeidsvoorwaarden en de verbeterde mobiliteits- en loopbaanmogelijkheden in de zorgsector spelen daarbij een belangrijke rol, temeer ook daar deze factoren duidelijk bijdragen aan het betere imago van het werk in de zorgsector. Bovendien verbetert de aansluiting tussen onderwijs en arbeidsmarkt door de totstandkoming van een meer efficiënt opleidingsstelsel met adequaat op de verschillende deskundigheidsniveaus afgestemde 'koninklijke leerwegen'.

Het gemiddeld opleidingsniveau van de schoolverlaters gaat in het Balanced Growth scenario aanzienlijk omhoog. Enerzijds komt dit doordat de inefficiënte leerroutes van HAVO naar MBO en van VWO naar HBO duidelijk kleiner van omvang worden. Anderzijds is er met name bij meisjes een grote geneigdheid om na het MAVO of het VBO verder te leren in het DGO. Verder wordt in dit scenario een aanzienlijke rendementsverbetering in het leerlingwezen bewerkstelligd. Ten slotte is er sprake van een toenemende instroom van nieuwkomers op het laagste kwalificatieniveau (de beroepsgroep helpenden). Dit grotere aanbod wordt bewerkstelligd door de betere werking van de arbeidsmarkt voor de lagere opleidingscategorieën als gevolg van de grotere loonflexibiliteit en de versterkte incentives voor participatie op de arbeidsmarkt.

\subsection{Uitbreidingsvraag}

In Balanced Growth blijft de verwachte werkgelegenheidsgroei duidelijk achter bij de uitbreidingsvraag in het Global Shift scenario. Tabel 6.1 laat zien dat de werkgelegenheid in de zorgsector in de periode 1993-2005 naar verwachting in totaal met ruim 97.000 arbeidsplaatsen zal toenemen. Dat komt overeen met een groei van gemiddeld 2,5\% per jaar. Evenals in 
Global Shift is de demografische ontwikkeling een belangrijke oorzaak voor de werkgelegenheidsgroei in de zorgsector. In Balanced Growth wordt de zorgvraag bovendien gestimuleerd door de toegenomen financiële ruimte als gevolg van de hogere economische groei.

Tabel 6.1. Uitbreidingsvraag per deelsector scenario Balanced Growth 1993-2005 (totaal aantal en gemiddelde jaarlijkse groei)

\begin{tabular}{lrc} 
Deelsector & aantal & $\%$ \\
\hline Ziekenhuizen & 2.300 & 0,3 \\
Psychiatrische ziekenhuizen & 10.900 & 4,9 \\
Verpleeghuizen & 20.500 & 3,7 \\
Gehandicaptenzorg & 3.900 & 1,7 \\
Gezinszorg & 27.300 & 2,3 \\
Kruiswerk & 7.300 & 2,9 \\
Bejaardenoorden & 25.100 & 3,8 \\
Totaal & & 2,5 \\
\hline
\end{tabular}

Bron: ROA

Het afremmen van de werkgelegenheidsgroei is dan ook geheel toe te schrijven aan het gevoerde beleid ten aanzien van de verschillende zorgsectoren. De geringere groei is vooral het gevolg van de aanzienlijk hogere eigen bijdragen, de omvorming en de personeelsbesparingen als gevolg van de substitutieprocessen van relatief dure zorgvormen naar goedkopere vormen van zorg. Maar ook de diffusie van produktiviteitsverhogende technologische vernieuwingen in de ziekenhuizen, de invoering van 'managed care' systemen en de omvorming van bejaardenoorden in 'woon-zorg-complexen' heeft een remmende werking op de werkgelegenheidsontwikkeling.

De werkgelegenheidstoename is, met een groeipercentage van bijna gemiddeld $5 \%$ per jaar, verhoudingsgewijs het grootst bij de psychiatrische ziekenhuizen. Deze groei wijkt niet veel af van de verwachte uitbreidingsvraag in deze deelsector in het Global Shift scenario. Ook bij de bejaardenoorden en de verpleeghuizen is de uitbreidingsvraag relatief hoog als gevolg van de sterke doorwerking van de demografische druk op de zorgvraag in deze sectoren. Met name bij de bejaardenoorden valt de werkgelegenheidsgroei echter veel lager uit dan bij Global Shift. Daarbij gaat het om een verschil van circa 14.000 arbeidsplaatsen. De verhoging van de eigen bijdragen in deze deelsector en de omvorming van bejaardenoorden in woon-zorg-complexen zijn daarvan de belangrijkste oorzaken. Desalniettemin bedraagt de werkgelegenheidstoename bij de bejaardenoorden altijd nog ruim 25.000 arbeidsplaatsen.

Ook in de ziekenhuissector blijft de uitbreidingsvraag sterk achter bij die in het Global Shift scenario. Er wordt slechts een werkgelegenheidsgroei van gemiddeld $0,3 \%$ per jaar verwacht. De sterke afremming van de werkgelegenheidsgroei in deze sector is voor meer dan de helft het gevolg van de substitutie van intramurale zorg door extramurale zorg. Daarnaast draagt de 
diffusie van produktiviteitsverhogende technologische ontwikkelingen en de introductie van 'managed care' systemen aanzienlijk bij aan het afremmen van de werkgelegenheidstoename in deze deelsector. Daarbij wordt opgemerkt dat de besparing in de werkgelegenheid vooral bij de verpleegkundige en verzorgende beroepen plaatsvindt en in veel geringere mate bij de artsen, medisch specialisten e.d.

Daarentegen wordt in het Balanced Growth scenario voor de gezinszorg en het kruiswerk een ietwat grotere uitbreidingsvraag verwacht dan bij Global Shift. Daarbij gaat het bij de gezinszorg om maar liefst ruim 27.000 nieuwe arbeidsplaatsen. Deze hogere werkgelegenheidsgroei is enerzijds toe te schrijven aan de grotere financiële ruimte voor de zorgsector in het algemeen, maar daarnaast ook aan de substitutie van zorgtaken van intramurale sectoren naar deze extramurale deelsectoren. Daar staat overigens tegenover dat de verhoging van eigen bijdragen ook in deze sector een substantieel remmende werking heeft op de werkgelegenheidsontwikkeling.

In het Balanced Growth scenario blijft voor alle beroepsgroepen de uitbreidingsvraag achter bij de in het Global Shift scenario verwachte werkgelegenheidstoename. De werkgelegenheidstoename is evenals bij Global Shift verhoudingsgewijs het grootst voor de verzorgenden. De gemiddelde jaarlijkse groei van de werkgelegenheid bedraagt voor deze beroepsgroep $4,6 \%$. Daarbij is er sprake van in totaal circa 32.000 nieuwe arbeidsplaatsen, ruim $\mathbf{8 . 0 0 0}$ minder dan bij Global Shift. Deze geringere groei is vooral het gevolg van de verhoogde eigen bijdragen in de extramurale sector en de omvorming van bejaardenoorden in woon-zorg-complexen. Ook bij de ziekenverzorgenden is de uitbreidingsvraag relatief hoog. Het achterblijven van de werkgelegenheidstoename in deze beroepsgroep ten opzichte van het Global Shift scenario is voor bijna de helft het gevolg van de substitutie van zorgverlening in de verpleeghuizen door extramurale zorg.

Tabel 6.2. Uitbreidingsvraag per beroepsgroep scenario Balanced Growth 1993-2005 (totaal aantal en gemiddelde jaarlijkse groei)

\begin{tabular}{lcc} 
Beroepsgroep & aantal & $\%$ \\
\hline Verpleegkundigen & 24.600 & 1,8 \\
Ziekenverzorgenden & 24.400 & 3,4 \\
Verzorgenden & 32.100 & 4,6 \\
Helpenden & 16.100 & 1,6 \\
Totaal & 97.200 & 2,5 \\
\hline
\end{tabular}

Bron: ROA

Bij de verpleegkundigen en de helpenden is er slechts sprake van een gemiddelde jaarlijkse werkgelegenheidsgroei van respectievelijk $1,6 \%$ en $1,8 \%$. Vooral bij de verpleegkundigen is het verschil met het Global Shift scenario groot. Balanced Growth verwacht voor deze beroepsgroep 
circa 14.000 nieuwe arbeidsplaatsen minder dan in het Global Shift scenario. De sterke afremming van de werkgelegenheidstoename voor deze beroepsgroep is vooral toe te schrijven aan de personeelsbesparing die gepaard gaat met de substitutieprocessen van de intramurale zorgsectoren naar de extramurale sectoren. Daarnaast draagt ook de diffusie van produktiviteitsverhogende technologische ontwikkelingen in de ziekenhuissector en de introductie van 'managed care' in de intramurale sectoren in aanzienlijke mate bij aan de reductie van de werkgelegenheidstoename voor deze beroepsgroep.

\subsection{Vervangingsvraag}

Vanwege de aanzienlijk hogere participatiegraad van vrouwen en de betere concurrentiepositie van de zorgberoepen op de arbeidsmarkt is de vervangingsvraag naar schoolverlaters in het Balanced Growth scenario nog niet de helft van de vervangingsbehoefte aan schoolverlaters die in het Global Shift scenario wordt verwacht. Uit tabel 6.3 blijkt dat in totaal tot het jaar 2005 naar verwachting bijna 70.000 arbeidsplaatsen moeten worden opgevuld door schoolverlaters die in deze periode instromen op de arbeidsmarkt. Dit is gemiddeld gezien nog geen $2 \%$ per jaar en maar liefst 95.000 arbeidsplaatsen minder dan bij Global Shift. Zoals reeds eerder is aangegeven, is bij deze vervangingsvraagprognose de op grond van de participatiegraadontwikkelingen verwachte instroom van herintreders volledig verdisconteerd, zodat de vervangingsvraag, en overigens ook de uitbreidingsvraag, volledig door schoolverlaters moet worden opgevangen.

Tabel 6.3. Vervangingsvraag naar schoolverlaters per deelsector scenario Balanced Growth 1993-2005 (totaal aantal en gemiddeld jaarlijks percentage)

$\begin{array}{lll}\text { Deelsector } & \text { aantal } & \%\end{array}$

$\begin{array}{lrr}\text { Ziekenhuizen } & 13.000 & 1,7 \\ \text { Psychiatrische ziekenhuizen } & 3.300 & 1,8 \\ \text { Verpleeghuizen } & 8.300 & 1,7 \\ \text { Gehandicaptenzorg } & 2.500 & 1,1 \\ \text { Gezinszorg } & 28.100 & 2,3 \\ \text { Kruiswerk } & 3.300 & 1,5 \\ \text { Bejaardenoorden } & 10.500 & 1,8 \\ & & 1,9 \\ \text { Totaal } & 69.100 & \end{array}$

Bron: ROA

In tegenstelling tot het Global Shift scenario, is bij Balanced Growth de vervangsbehoefte aan schoolverlaters relatief gezien niet het hoogst bij de intramurale sectoren, maar bij de gezinszorg. De gemiddelde jaarlijkse vervangingsvraag bedraagt hier 2,3\%. Daarbij gaat het om ruim 28.000 vrijkomende arbeidsplaatsen die door schoolverlaters dienen te worden opgevuld. In alle andere deelsectoren zijn de verschillen met Global Shift verhoudingsgewijs veel groter. Zo is bij de ziekenhuizen, de psychiatrische ziekenhuizen en de verpleeghuizen de vervangsbehoefte aan 
schoolverlaters gemiddeld nog geen $2 \%$, tegenover ruim $4,5 \%$ in het Global Shift scenario. De vervangingsvraag in de ziekenhuissector wordt mede afgeremd door de geringere doorstroom van jongere verpleegkundigen en ziekenverzorgenden naar beroepen buiten de zorgsector, als gevolg van de betere arbeidsvoorwaarden voor de werkenden in deze beroepsgroepen. In totaal heeft de vervangingsvraag naar schoolverlaters in deze sector tot het jaar 2005 in Balanced Growth slechts betrekking op 13.000 arbeidsplaatsen, tegenover circa 44.000 in het Global Shift scenario.

In de gehandicaptenzorg is de vervangingsvraag, met een gemiddelde jaarlijkse vervangingsbehoefte van ruim $1 \%$ erg gering. Tot het jaar 2005 gaat het daarbij slechts om 2.500 arbeidsplaatsen, tegenover maar liefst bijna 12.000 vrijkomende arbeidsplaatsen voor schoolverlaters in het Global Shift scenario. In de beide andere extramurale sectoren, het kruiswerk en de bejaardenoorden, ligt de vervangingsbehoefte aan schoolverlaters bij Balanced Growth verhoudingsgewijs ongeveer op hetzelfde niveau als in de intramurale sectoren. In absolute aantallen is de vervangingsvraag in de deelsector bejaardenoorden nog niet de helft van de vervangingsbehoefte in deze sector bij Global Shift. Daarbij moeten er naar verwachting bij de bejaardenoorden tot het jaar 2005 ruim 10.000 arbeidsplaatsen worden opgevuld door de tot die tijd op de arbeidsmarkt instromende schoolverlaters.

Tabel 6.4. Vervangingsvraag naar schoolverlaters per beroepsgroep scenario Balanced Growth 1993-2005 (totaal aantal en gemiddeld jaarlijks percentage)

\begin{tabular}{lrc} 
Beroepsgroep & aantal & $\%$ \\
\hline Verpleegkundigen & 22.000 & 1,6 \\
Ziekenverzorgenden & 10.700 & 1,6 \\
Verzorgenden & 9.600 & 1,6 \\
Helpenden & 26.800 & 2,5 \\
Totaal & 69.100 & 1,9 \\
\hline
\end{tabular}

Bron: ROA

Tabel 6.4 geeft een overzicht van de vervangingsvraag in Balanced Growth, verbijzonderd naar beroepsgroep. Verhoudingsgewijs is de vervangingingsbehoefte aan schoolverlaters het grootst bij de helpenden, met een gemiddelde jaarlijkse vervangingsbehoefte van $2,5 \%$. Bij de drie andere beroepsgroepen ligt de vervangingsvraag op het lage niveau van nog geen 1,6\% gemiddeld per jaar. In vergelijking met Global Shift is de vervangingsvraag vooral veel kleiner bij de verpleegkundigen en de ziekenverzorgenden. Daarbij is er in Balanced Growth tot 2005 slechts sprake van een vervangingsbehoefte aan verpleegkundigen van 22.000 arbeidsplaatsen, tegenover maar liefst bijna 74.000 arbeidsplaatsen in Global Shift. Voor de ziekenverzorgenden bedraagt de vervangingsbehoefte in het Balanced Growth scenario bijna 11.000 personen, tegenover ruim 35.000 personen in het Global Shift scenario. Deze verschillen illustreren het enorme belang van de participatiegraadontwikkeling voor de (netto) uitstroom van arbeidskrach- 
ten bij deze beide beroepsgroepen. Bovendien wordt de vervangingsbehoefte aan schoolverlaters, zoals gezegd, bij beide beroepsgroepen in het Balanced Growth scenario afgeremd door de geringere doorstroom van jonge arbeidskrachten naar werkvelden buiten de zorgsector.

\subsection{Baanopeningen}

Tabel 6.5 geeft een beeld van het totaal aantal baanopeningen dat tot het jaar 2005 in het Balanced Growth scenario voor de verschillende deelsectoren, op basis van de hierboven beschreven uitbreidingsvraag- en vervangingsvraagontwikkelingen, wordt verwacht. Het totaal aantal baanopeningen in Balanced Growth bedraagt ruim 165.000 arbeidsplaatsen, nog geen $60 \%$ van het in Global Shift verwachte aantal baanopeningen. Het grootste deel van de totale vraag naar schoolverlaters heeft betrekking op nieuwe arbeidsplaatsen als gevolg van de werkgelegenheidsgroei. Bij een vergelijking met het totaal aantal baanopeningen bij Global Shift, is de geringere vraag naar schoolverlaters bij Balanced Growth voor het grootste deel het gevolg van de aanzienlijk lagere vervangingsbehoefte.

Tabel 6.5. Aantal baanopeningen en procentuele verdeling over uitbreidingsvraag en vervangingsvraag per deelsector scenario Balanced Growth 1993-2005

\begin{tabular}{lccc}
\hline Deelsector & aantal & $\begin{array}{c}\text { uitbreidingsvraag } \\
\%\end{array}$ & $\begin{array}{c}\text { vervangingsvraag } \\
\%\end{array}$ \\
\hline Ziekenhuizen & & 15 & 85 \\
Psychiatrische ziekenhuizen & 15.300 & 77 & 23 \\
Verpleeghuizen & 14.200 & 71 & 29 \\
Gehandicaptenzorg & 28.700 & 60 & 40 \\
Gezinszorg & 6.400 & 49 & 51 \\
Kruiswerk & 55.500 & 69 & 31 \\
Bejaardenoorden & 10.600 & 71 & 29 \\
Totaal & 35.600 & 58 & 42 \\
\hline
\end{tabular}

Bron: ROA

Bij de verpleeghuizen, de bejaardenoorden en het kruiswerk heeft circa $70 \%$ van het totaal aantal baanopeningen betrekking op nieuwe arbeidsplaatsen als gevolg van de uitbreidingsvraag. Voor de sector psychiatrische ziekenhuizen geldt zelfs dat meer dan drie kwart van het aantal baanopeningen het gevolg is van de uitbreidingsvraag. In de gezinszorg zijn vervangingsvraag en uitbreidingsvraag beide goed voor ongeveer de helft van de baanopeningen. Daarentegen vloeit het overgrote deel van de totale vraag naar schoolverlaters bij de ziekenhuizen voort uit de vervangingsvraag. Het totaal aantal baanopeningen in deze sector bedraagt tot 2005 slechts 15.300 arbeidsplaatsen, ongeveer een kwart van de totale vraag naar schoolverlaters in deze sector bij Global Shift. Ook in de gehandicaptenzorg, de bejaardenoorden, de verpleeghuizen en de psychiatrische ziekenhuizen is het totaal aantal baanopeningen veel lager dan bij het Global Shift scenario. Voor het grootste deel is dit het gevolg van de lagere vervangingsbehoefte. In de 
gezinszorg is het aantal baanopeningen in Balanced Growth weliswaar ook duidelijker lager dan in Global Shift, maar deze sector is in het Balanced Growth scenario al met al toch goed voor een derde van het totaal aantal toekomstige baanopeningen. Bij het kruiswerk is de totale vraag naar schoolverlaters slechts iets kleiner dan in het Global Shift scenario. In deze sector wordt bij Balanced Growth de wat lagere vervangingsvraag gecompenseerd door een hogere werkgelegenheidstoename.

In tabel 6.6 wordt de totale vraag naar schoolverlaters verbijzonderd naar beroepsgroep. Uit de tabel valt op te maken dat bij de ziekenverzorgenden en de verzorgenden het grootste deel van de baanopeningen betrekking heeft op de uitbreidingsvraag. Bij de verpleegkundigen is de verhouding tussen uitbreidingsvraag en vervangingsvraag vrijwel fifty-fifty. Daarentegen zijn de meeste baanopeningen voor helpenden toe te schrijven aan de vervangingsvraag.

Tabel 6.6. Aantal baanopeningen en procentuele verdeling over uitbreidingsvraag en vervangingsvraag per beroepsgroep scenario Balanced Growth 1993-2005

\begin{tabular}{lccc}
\hline Beroepsgroep & aantal & $\begin{array}{c}\text { uitbreidingsvraag } \\
\%\end{array}$ & $\begin{array}{c}\text { vervangingsvraag } \\
\%\end{array}$ \\
\hline Verpleegkundigen & 46.600 & 53 & 47 \\
Ziekenverzorgenden & 35.100 & 70 & 30 \\
Verzorgenden & 41.700 & 77 & 23 \\
Helpenden & 42.900 & 38 & 62 \\
Totaal & 166.300 & 58 & 42 \\
\hline
\end{tabular}

Bron: ROA

Opvallend genoeg ligt het totaal aantal baanopeningen voor de vier onderscheiden beroepsgroepen vrij dicht bij elkaar, uiteenlopend van 35.000 baanopeningen voor ziekenverzorgenden tot bijna 47.000 baanopeningen voor verpleegkundigen. Bij de laatste beroepsgroep is de totale vraag naar schoolverlaters in Balanced Growth nog niet de helft van het aantal baanopeningen voor deze beroepsgroep in Global Shift. In dit laatste scenario is er sprake van maar liefst ruim 112.000 baanopeningen voor verpleegkundigen. Het geringere aantal baanopeningen in deze beroepsgroep is voor het grootste deel het gevolg van de lagere vervangingsvraag. Bij de ziekenverzorgenden is het totaal aantal baanopeningen eveneens veel lager dan in het Global Shift scenario. Ook in deze beroepsgroep is dit vooral het gevolg van de lagere vervangingsbehoefte. Voor de beroepsgroepen verzorgende en helpende geldt evenzeer dat het aandeel van de vervangingsvraag in het totaal aantal baanopeningen in Balanced Growth lager ligt dan in Global Shift. Daardoor is ook het totaal aantal baanopeningen voor deze beroepsgroepen in het Balanced Growth scenario geringer.

Tabel 6.7 geeft een overzicht van het totaal aantal in het Balanced Growth scenario verwachte baanopeningen tot 2005, verbijzonderd naar zowel deelsector als beroepsgroep. Bij de verpleegkundigen doen de meeste baanopeningen zich voor in de ziekenhuizen en de psychiatri- 
sche ziekenhuizen. Met uitzondering van het kruiswerk, en in iets mindere mate ook de psychiatrische ziekenhuizen, ligt het aantal baanopeningen voor deze beroepsgroep in alle deelsectoren op een aanzienlijk lager niveau dan in Global Shift. Vooral in de ziekenhuizen en de gehandicaptenzorg zijn de verschillen met Global Shift wat dit betreft het grootst. Bij de ziekenverzorgenden heeft het overgrote deel van de baanopeningen voor schoolverlaters betrekking op de sector verpleeghuizen. Tot het jaar 2005 worden er in deze sector bij Balanced Growth ruim 23.000 baanopeningen voor ziekenverzorgenden verwacht. Met uitzondering van het kruiswerk is ook bij deze beroepsgroep over de gehele linie het aantal baanopeningen veel lager dan in het Global Shift scenario.

Bij de verzorgenden doen de meeste baanopeningen zich voor in de gezinszorg en de bejaardenoorden. Vooral in deze laatstgenoemde sector is het totaal aantal baanopeningen echter aanmerkelijk kleiner dan in het Global Shift scenario. Bij de helpenden is de gezinszorg goed voor ruim $90 \%$ van de baanopeningen voor schoolverlaters. Zowel in de gezinszorg als in de bejaardenoorden blijft ook voor deze beroepsgroep het totaal aantal baanopeningen achter bij de totale vraag in het Global Shift scenario.

Tabel 6.7. Aantal baanopeningen verbijzonderd naar deelsector en beroepsgroep scenario Balanced Growth 1993-2005

\begin{tabular}{lccrc}
\hline Deelsector & verpleeg- & $\begin{array}{l}\text { Beroepsgroep } \\
\text { zieken- } \\
\text { verzorgenden }\end{array}$ & verzorgenden & helpenden \\
\hline Ziekenhuizen & 15.400 & 700 & - & - \\
$\begin{array}{l}\text { Psychiatrische ziekenhuizen } \\
\text { Verpleeghuizen }\end{array}$ & 15.100 & 2.100 & - & - \\
Gehandicaptenzorg & 5.400 & 23.300 & - & - \\
Gezinszorg & 6.200 & 200 & - & 39.500 \\
Kruiswerk & 5.300 & 2.600 & 15.900 & - \\
Bejaardenoorden & 2.200 & 7.000 & 23.100 & 3.400 \\
\hline
\end{tabular}

Bron: ROA

\subsection{Instroom van schoolverlaters}

Tegenover het geringere aantal baanopeningen in vergelijking met het Global Shift scenario staat in Balanced Growth een wat hogere instroom van schoolverlaters op de arbeidsmarkt voor de zorgsector. Tabel 6.8 laat zien dat in Balanced Growth in de periode 1993-2005 in totaal ruim 170.000 schoolverlaters voor het eerst op zoek gaan naar een baan in de zorgsector. Verhoudingsgewijs is de arbeidsmarktinstroom het hoogst bij de verzorgenden, met een gemiddelde jaarlijkse instroom van $6 \%$. Daarentegen is de instroom van schoolverlaters relatief het laagst bij de verpleegkundigen. Voor deze beroepsgroep bedraagt de toekomstige instroom gemiddeld ruim $3 \%$ per jaar. De beide andere beroepsgroepen nemen wat betreft de instroom van schoolverlaters een middenpositie in, al ligt de arbeidsmarktinstroom bij ziekenverzorgenden 
gemiddeld toch bijna een procent-punt hoger dan bij de helpenden.

In absolute aantallen is de arbeidsmarktinstroom van schoolverlaters het grootst bij de verpleegkundigen. In totaal zullen zich in Balanced Growth tot 2005 ruim 50.000 schoolverlaters aanmelden voor een baan als verpleegkundige. Dit aantal is echter opvallend veel lager dan de verwachte arbeidsmarktinstroom van schoolverlaters op dit beroepssegment in het Global Shift scenario (circa 75.000). Deze geringere instroom van schoolverlaters is deels toe te schrijven aan de grotere doorstroom van HAVO-leerlingen naar het HBO in plaats van naar het DGO. Daarnaast neemt de arbeidsmarktinstroom van schoolverlaters af als gevolg van het afsluiten van de mogelijkheid voor MAVO- en VBO-gediplomeerden om direct in te stromen in de inservice-opleidingen die opleiden voor het hoogste deskundigheidsniveau. Daar staat tegenover dat de doorstroom van MAVO- en VBO-leerlingen naar het DGO toeneemt.

Tabel 6.8. Instroom van schoolverlaters per beroepsgroep scenario Balanced Growth 1993-2005 (totaal aantal en gemiddeld jaarlijks percentage)

\begin{tabular}{lrr} 
Beroepsgroep & aantal & $\%$ \\
\hline Verpleegkundigen & 50.200 & 3,3 \\
Ziekenverzorgenden & 35.200 & 4,6 \\
Verzorgenden & 44.500 & 6,0 \\
Helpenden & 42.900 & 3,7 \\
Totaal & 172.800 & 4,1
\end{tabular}

Bron: ROA

Tegenover de in Balanced Growth lagere arbeidsmarktinstroom van verpleegkundigen, staat dat de instroom van schoolverlaters bij de helpenden juist op een veel hoger niveau ligt dan in Global Shift. Dit veel grotere aanbod van schoolverlaters voor een functie als helpende is vooral het gevolg van het beter functioneren van de arbeidsmarkt voor de lagere opleidingscategorieën, vanwege de sterkere prikkels voor participatie op de arbeidsmarkt en de grotere loonflexibiliteit.

Bij de verzorgenden is de in Balanced Growth verwachte arbeidsmarktinstroom van schoolverlaters wat groter dan in het Global Shift scenario, als gevolg van het toenemende aantal jongeren dat na het MAVO of het VBO een opleiding in het DGO gaat volgen. Bij de ziekenverzorgenden ligt de instroom van schoolverlaters op de arbeidsmarkt vrijwel op hetzelfde niveau als in het Global Shift scenario.

\subsection{Toekomstige arbeidsmarktsituatie}

In tabel 6.9 wordt een overzicht gegeven van de op basis van de bovenstaande ontwikkelingen volgens het Balanced Growth scenario voor het jaar 2005 verwachte aanbodoverschotten of -tekorten op de vier onderscheiden beroepssegmenten. Uit de tabel blijkt dat de in Global Shift 
verwachte aanbodtekorten voor verpleegkundigen, ziekenverzorgenden en verzorgenden zich in Balanced Growth in het geheel niet zullen voordoen.

De tabel laat zien dat de totale vraag naar schoolverlaters in Balanced Growth in 2005 vrijwel in evenwicht is met de arbeidsmarktinstroom van schoolverlaters. Bij de verpleegkundigen ligt het aanbodoverschot van 2,8\% ongeveer op een niveau dat doorgaans gezien wordt als het voor een adequate werking van de arbeidsmarkt vereiste frictiewerkloosheidsniveau. Bij de verzorgenden is het verwachte aanbodoverschot slechts een fractie hoger: $3,6 \%$.

Tabel 6.9. Aanbodoverschot of -tekort per beroepsgroep scenario Balanced Growth in 2005 (totaal aantal en relatief ten opzichte van de verwachte vraag in 2005)

\begin{tabular}{lrr}
\hline Beroepsgroep & aantal & $\%$ \\
\hline Verpleegkundigen & 3.600 & 2,8 \\
Ziekenverzorgenden & 200 & 0,2 \\
Verzorgenden & 2.800 & 3,6 \\
Helpenden & 0 & 0,0 \\
Totaal & 6.500 & 1,7 \\
\hline
\end{tabular}

Bron: ROA

Het aanbodoverschot bij de ziekenverzorgenden ligt daarentegen duidelijk onder het frictiewerkloosheidsniveau, zodat de sectoren waar sprake is van veel baanopeningen voor deze beroepsgroep enige knelpunten kunnen ondervinden bij de werving van adequaat opgeleid personeel. Hierbij gaat het met name om de verpleeghuizen en de bejaardenoorden. Voor de helpenden wordt verwacht dat vraag en aanbod geheel met elkaar in evenwicht zijn. Zoals gezegd, bewerkstelligt de verbeterde werking van de arbeidsmarkt voor de lagere opleidingsniveaus dat het arbeidsaanbod toereikend zal zijn om de baanopeningen voor schoolverlaters zonder grote recruteringsproblemen op te kunnen vullen. 


\section{EUROPEAN RENAISSANCE}

\subsection{Inleiding}

In dit hoofdstuk worden de arbeidsmarktontwikkelingen in de zorgsector volgens het European Renaissance scenario gepresenteerd. Het hoofdstuk heeft dezelfde opzet als de beide voorgaande hoofdstukkken. Na een verdere uitwerking van het in hoofdstuk 4 globaal beschreven karakter van het European Renaissance scenario, zal achtereenvolgens worden ingegaan op de verwachte ontwikkelingen aan de vraag- en aanbodzijde van de arbeidsmarkt in de zorgsector. Daarbij zal een verbijzondering worden gemaakt naar deelsector en beroepsgroep. Ten slotte wordt op basis van een confrontatie van de vraag- en aanbodontwikkelingen een beeld geschetst van de voor het jaar 2005 verwachte arbeidsmarktsituatie voor de vier in deze studie onderscheiden beroepsgroepen in de zorgsector.

\section{Uitbreidingsvraag}

In het European Renaissance scenario is, evenals in het Balanced Growth scenario sprake van een relatief hoge economische groei, al blijft het tot het jaar 2005 verwachte gemiddelde jaarlijkse groeipercentage van $2,7 \%$ iets achter bij de groeiverwachtingen in het Balanced Growth scenario. Hoewel de jaarlijkse groei van de totale werkgelegenheid van $0,7 \%$ ook enigszins achter blijft bij de werkgelegenheidsontwikkeling in het Balanced Growth scenario, ligt de verwachte werkgelegenheidstoename in de kwartaire dienstverlening in beide scenario's op hetzelfde niveau (gemiddeld $2,4 \%$ per jaar).

In het European Renaissance scenario ligt de nadruk op het Coördinatie-perspectief. Zoals in hoofdstuk 4 reeds is aangegeven, wordt verondersteld dat er in de gezondsheidszorg met succes een stelselwijziging wordt doorgevoerd. Daarbij zal $95 \%$ van de huidige zorgvoorzieningen in een verplichte basisverzekering worden opgenomen.

Doordat de zorgverzekeraars beter in staat zijn om tegenspel te bieden aan de zorgaanbieders en de aanbieders door de vereenvoudigde aanbodwetgeving ook in staat worden gesteld om zorg op maat aan te bieden, zullen aanzienlijke efficiency-voordelen kunnen worden gerealiseerd. Deze efficiëncy-voordelen worden in de ziekenhuissector voornamelijk behaald door de produktiviteitsstijgingen die voortvloeien uit de diffusie van technologische vernieuwingen. Ook hier worden de binnen het huidige budgetteringssysteem voor ziekenhuizen bestaande belemmeringen voor de diffusie van endoscopische chirurgie, diagnostische laparoscopie e.d. weggenomen. Dit leidt enerzijds tot een aanzienlijke daling van het aantal verpleegdagen in de ziekenhuissector, terwijl bovendien vanwege de veel snellere hersteltijd de zorgvraag in de wijkverpleging, de gezinszorg en de bejaardenoorden afneemt (zie ook Balanced Growth). Wel wordt het tempo van het diffusieproces van deze technologische vernieuwingen enigszins afgeremd door het tekortschietende aanbod van medisch specialisten, een bottleneck die voortvloeit uit de langere operatieduur bij endoscopische chirurgie (zie Dirksen, Ament, Go en Hupkens van der Elst, 1994). 
De nadruk die de overheid gaat leggen op de kwaliteitscontrole zal eveneens in aanzienlijke mate kunnen bijdragen aan efficiency-verbeteringen in de verschillende zorgsectoren. Door 'utilization review' zullen de zorgverzekeraars de kosten van behandelingsprocessen goed kunnen evalueren. Daarbij vergelijkt men individuele patiënt- of instellingsgegevens met de statistische gemiddelden uit de verzamelde geaggregeerde data (zie Feldstein, 1988). De zorginstellingen zullen op deze kwaliteitscontroles zelf ook inspelen door het invoeren van 'case management' e.d.

Een belangrijk kenmerk van het European Renaissance scenario is ook de 'extramuralisering' van de zorgsector als gevolg van het aanbieden van 'zorg op maat'. De deelsectoren in de intramurale sector stoten taken af. Deels zullen deze door de thuiszorg worden overgenomen. De efficiency van de zorgsector als geheel verbetert door dit substitutieproces aanzienlijk. De ziekenhuizen zullen daarbij in belangrijke mate hun 'hotelfunctie' verliezen, waardoor het aandeel van verpleegkundigen en vooral ook van ziekenverzorgenden in de totale werkgelegenheid in deze deelsector verder zal afnemen. Ook het aantal opnamen in psychiatrische ziekenhuizen, verpleeghuizen en de instellingen voor gehandicaptenzorg wordt afgeremd door vaker en langer gebruik te blijven maken van de voorzieningen in het kruiswerk en de gezinszorg. Bovendien zal door de overheidsinvesteringen in de technologische ontwikkeling van de extramurale zorg, de intramurale zorg op een aantal gebieden uit de markt worden geprezen. Veel kleine behandelingen die nu nog in de ziekenhuissector plaatsvinden, zullen daardoor kunnen worden overgenomen door poliklinieken, huisartsen en kleine gezondheidscentra. Daarnaast zullen er ook verschuivingen optreden in de zorgvraag van de verpleeghuizen en de gehandicaptenzorg naar de thuiszorg. Ten slotte zal er door de verkleining van de wachtlijsten van de verpleeghuizen ook een geringe verschuiving plaatsvinden van de zorgverlening in ziekenhuizen naar de verpleeghuizen.

\section{Vervangingsvraag}

Vanwege de hogere participatie van vrouwen in het arbeidsproces is er ook in het European Renaissance scenario sprake van een aanzienlijke daling van de vervangingsbehoefte. Daarnaast neemt het verloop af als gevolg van de meer marktconforme salariëring en de verbeterde secundaire arbeidsvoorwaarden. Evenals in het Balanced Growth scenario, gaat er door de dalende instroom van arbeidskrachten uit de gezondheidssector in de WAO een remmende werking op de vervangingsbehoefte uit, vooral samenhangend met het sterk aangescherpte reïntegratiebeleid en de ARBO-wetgeving.

In tegenstelling tot het Balanced Growth scenario is de arbeidsmobiliteit tussen de deelsectoren binnen de zorgsector beperkt, mede doordat in European Renaissance meer arbeidskrachten een inservice-opleiding of een opleiding in het leerlingwezen hebben gevolgd, die in tegenstelling tot de dagopleidingen specifiek gericht zijn op een bepaalde deelsector. Wel zal bij de verpleegkundigen en ziekenverzorgenden door de verbeterde opleidingen en de studie- en beroepskeuzevoorlichting de hoge doorstroom van jongere arbeidskrachten naar beroepen buiten de zorgsector aanzienlijk verminderen. Ook de verbeterde secundaire arbeidsvoorwaarden en het 
vermijden van ontslag van werkenden direct na het behalen van het diploma van een inserviceopleiding zal daar in niet onbelangrijke mate toe bijdragen.

\section{Instroom van schoolverlaters}

Doordat binnen het arbeidsvoorwaardenoverleg een goede basis is gelegd voor een adequaat opleidings- en bijscholingsbeleid in de verschillende deelsectoren langs duale leerwegen, zijn de zorginstellingen beter in staat nieuwkomers te recruteren voor de verschillende zorgberoepen. Ook het verbeterde imago van het werk in de zorgsector speelt daarbij een rol.

In tegenstelling tot het Balanced Growth scenario wordt de grotere arbeidsmarktinstroom van schoolverlaters vooral gerealiseerd via deze duale leertrajecten, waarbij ook jongens in toenemende mate deze opleidingen gaan volgen. Ook is er in dit scenario, net als in Balanced Growth, sprake van een forse rendementsverbetering bij het leerlingwezen. De aantrekkelijkheid van deze opleidingen wordt daarnaast vooral vergroot door de verbeterde financieringsgrondslag, waardoor extreme cyclische fluctuaties in de leerlingenaantallen van de inserviceopleidingen tot het verleden behoren. Dit wordt bewerkstelligd door de introductie van opleidingsfondsen, die inhouden dat zorgsectoren een bepaald percentage van de loonsom voor de verpleegkundige en verzorgende beroepen aan initiële opleidingen en vervolgcursussen besteden. Daarbij staan individuele zorginstellingen voor de keus om een bepaald percentage van hun loonsom te besteden aan het opleiden van nieuwkomers, of indien ze niet zelf willen of kunnen opleiden (een deel van) dit geld te storten in een opleidingsfonds. Zo'n opleidingsfonds gebruikt dit geld voor de financiering van de inservice-opleiding bij zorginstellingen die een grotere opleidingsinspanning willen verrichten dan is vereist.

In aansluiting daarop wordt de arbeidsmarktinstroom van nieuwkomers in de zorgsector eveneens bevorderd door de intensieve bemoeienis van de Arbeidsvoorzieningsorganisatie met om- en bijscholingstrajecten gericht op de verschillende zorgsectoren. De basis voor dit Arbeidsvoorzieningsbeleid wordt gevormd door de convenanten ten aanzien van de afstemming tussen onderwijs en arbeidsmarkt die op regionaal niveau worden afgesloten. Naast de scholingsinstrumenten van de Arbeidsvoorzieningsorganisatie spelen daarbij ook de Jeugdwerkgarantieregelingen en banenpools een belangrijke rol. Langs deze weg is er vooral ook sprake van een aanzienlijke toename van de arbeidsinstroom van helpenden.

\subsection{Uitbreidingsvraag}

Ook in European Renaissance blijft de uitbreidingsvraag in de zorgsector duidelijk achter bij de verwachte werkgelegenheidsgroei in het Global Shift scenario. Wel is de werkgelegenheidstoename wat groter dan bij Balanced Growth. Zoals tabel 7.1 laat zien wordt er in European Renaissance voor de periode 1993-2005 in totaal een uitbreidingsvraag van 105.000 arbeidsplaatsen verwacht. Dit betekent dat de werkgelegenheid in de zorgsector met gemiddeld 2,7\% per jaar toeneemt. Evenals in de beide andere scenario's is deze groei grotendeels toe te schrijven aan de vergrijzing van de bevolking in ons land. Daarnaast stimuleert de als gevolg van 
de relatief hoge economische groei toegenomen financiële ruimte de maatschappelijke vraag naar zorg.

Tabel 7.1. Uitbreidingsvraag per deelsector scenario European Renaissance 1993-2005 (totaal aantal en gemiddelde jaarlijkse groei)

\begin{tabular}{lrr} 
Deelsector & aantal & $\%$ \\
\hline Ziekenhuizen & & \\
Psychiatrische ziekenhuizen & 4.100 & 0,6 \\
Verpleeghuizen & 10.000 & 4,6 \\
Gehandicaptenzorg & 18.500 & 3,4 \\
Gezinszorg & 3.200 & 1,4 \\
Kruiswerk & 34.700 & 2,8 \\
Bejaardenoorden & 8.600 & 3,4 \\
Totaal & 26.000 & 3,9 \\
& 105.100 & 2,7 \\
\hline
\end{tabular}

Bron: ROA

Het achterblijven van de werkgelegenheidsgroei bij de hoge uitbreidingsvraag in Global Shift is voor een aanzienlijk deel toe te schrijven aan de personeelsbesparingen die voortvloeien uit de substitutie van duurdere naar goedkopere vormen van zorg ('zorg op maat'). Daarnaast dragen ook de efficiency-verbeteringen vanwege het doorvoeren van organisatorische vernieuwingen ('utilization review' en 'case management') bij tot het afremmen van de werkgelegenheidstoename in de zorgsector. Bovendien is er, zij het in iets mindere mate dan in Balanced Growth, sprake van een lagere werkgelegenheidsgroei door de diffusie van produktiviteitsverhogende technologische vernieuwingen. Evenals in Balanced Growth geldt ook in European Renaissance dat de werkgelegenheidsbesparing voor de verpleegkundige en verzorgende beroepen relatief groter is dan voor de medische beroepen.

Uit de tabel blijkt dat de uitbreidingsvraag evenals in het Balanced Growth scenario het grootst is bij de psychiatrische ziekenhuizen. De werkgelegenheidstoename in deze sector bedraagt gemiddeld ruim 4,5\% per jaar. Bij de bejaardenoorden, de verpleeghuizen en het kruiswerk ligt de uitbreidingsvraag eveneens boven de gemiddelde werkgelegenheidsgroei in de zorgsector. In overeenstemming met het beeld in Balanced Growth blijft vooral bij de bejaardenoorden de uitbreidingsvraag aanmerkelijk achter bij die voor deze deelsector in Global Shift wordt verwacht. Dit is het gevolg van de omzetting van bejaardenoorden in woon-zorg-complexen en de verschuiving van een deel van de bejaardenzorg naar de thuiszorg.

Bij een vergelijking van de uitbreidingsvraag per deelsector met de werkgelegenheidstoename in Balanced Growth valt op dat in European Renaissance vooral in de extramurale sectoren de uitbreidingsvraag op een iets hoger niveau ligt. Het grootst is dit verschil bij de gezinszorg, waar de uitbreidingsvraag zelfs ruim 7.000 arbeidsplaatsen hoger is. Deze verschillen zijn voor een groot deel toe te schrijven aan de hogere eigen bijdragen die in Balanced Growth worden gevraagd als men een beroep doet op extramurale zorgverlening. Daar komt nog bij dat in 
European Renaissance sprake is van een grotere substitutie van intra- door extramurale zorgverlening.

In de ziekenhuissector is de uitbreidingsvraag in European Renaissance eveneens wat groter dan in Balanced Growth, hoewel ook in deze deelsector de werkgelegenheidsgroei met gemiddeld slechts $0,6 \%$ per jaar sterk achterblijft bij de uitbreidingsvraag in het Global Shift scenario. Het verschil in werkgelegenheidsontwikkeling tussen Balanced Growth en European Renaissance is vooral het gevolg van het feit dat het diffusieproces van produktiviteitsverhogende technologische vernieuwingen in het laatstgenoemde scenario enigszins wordt afgeremd. Dit komt vooral doordat het tekortschietende aanbod van medisch specialisten een knelpunt vormt voor een snellere diffusie van endoscopische chirurgie e.d.

Ook in de gehandicaptenzorg is de uitbreidingingsvraag in European Renaissance erg laag. De gemiddelde jaarlijkse werkgelegenheidsgroei is nog geen $1,5 \%$. De toename van de werkgelegenheid in deze deelsector ligt daarmee zelfs onder het niveau van de uitbreidingsvraag in Balanced Growth. Dit is vooral het gevolg van de verder gaande organisatorische vernieuwingen in de vorm van utilization review en case management.

Tabel 7.2 laat zien dat evenals in beide andere scenario's de uitbreidingsvraag bij de verzorgenden verhoudingsgewijs het grootst is. Het gaat hier in totaal om 35.000 nieuwe arbeidsplaatsen, een werkgelegenheidstoename waarmee European Renaissance ten opzichte van beide andere scenario's een tussenpositie inneemt. Personeelsbesparingen als gevolg van de overheveling van zorgtaken van de relatief dure intramurale zorgsectoren naar de goedkopere extramurale zorg, zorgen voor het achterblijven van de werkgelegenheidsgroei bij Global Shift. Het niet doorvoeren van veel hogere eigen bijdragen voor de extramurale zorgverlening is de belangrijkste oorzaak voor de wat hogere uitbreidingsvraag voor verzorgenden in vergelijking met het Balanced Growth scenario.

Tabel 7.2. Uitbreidingsvraag per beroepsgroep scenario European Renaissance 1993-2005 (totaal aantal en gemiddelde jaarlijkse groei)

\begin{tabular}{lrc} 
Beroepsgroep & aantal & $\%$ \\
\hline Verpleegkundigen & 26.700 & 1,9 \\
Ziekenverzorgenden & 21.800 & 3,1 \\
Verzorgenden & 35.000 & 5,0 \\
Helpenden & 21.600 & 2,1 \\
Totaal & 105.100 & 2,7 \\
\hline
\end{tabular}

Bron: ROA

De werkgelegenheidstoename voor de ziekenverzorgenden is eveneens meer dan het gemiddelde voor de gehele zorgsector. De uitbreidingsvraag is met gemiddeld 3,1\% per jaar iets geringer 
dan in het Balanced Growth scenario. Dit is met name het gevolg van de meer omvangrijke substitutieprocessen van de intramurale zorg naar de extramurale zorgsectoren. Bij de verpleegkundigen en de helpenden ligt de uitbreidingsvraag daarentegen met een gemiddelde van circa $2 \%$ per jaar op een veel lager niveau. Vooral voor de helpenden is deze groei in European Renaissance wat hoger dan in Balanced Growth. Dit komt met name door het niet doorvoeren van hogere eigen bijdragen in de extramurale zorg en de in European Renaissance verder gaande substitutie van intra- naar extramurale zorgverlening.

\subsection{Vervangingsvraag}

De vervangingsbehoefte aan schoolverlaters ligt in European Renaissance op een iets hoger niveau dan in Balanced Growth. Uit tabel 7.3 blijkt dat gemiddeld jaarlijks 2,5\% van de bestaande arbeidsplaatsen opnieuw moet worden opgevuld door schoolverlaters die instromen op de arbeidsmarkt. In totaal gaat het daarbij tot 2005 om bijna 100.000 arbeidsplaatsen. Overigens blijft daarmee ook in European Renaissance de vervangingsvraag sterk achter bij die in Global Shift. In dat scenario is sprake van een totale vervangingsbehoefte van bijna 165.000 arbeidsplaatsen. Het verschil is ook hier voor het grootste deel het gevolg van de veel hogere arbeidsparticipatie van vrouwen waardoor er in vergelijking met Global Shift meer herintreders in de zorgsector zullen instromen, hetgeen het beslag dat op schoolverlaters moet worden gelegd kleiner maakt. Wel is de doorstroom van arbeidskrachten naar beroepen buiten de zorgsector wat groter dan in Balanced Growth, terwijl bovendien de participatiegraad in het algemeen in European Renaissance iets lager ligt.

Tabel 7.3. Vervangingsvraag naar schoolverlaters per deelsector scenario European Renaissance 19932005 (totaal aantal en gemiddeld jaarlijks percentage)

\begin{tabular}{lrc} 
Deelsector & aantal & $\%$ \\
\hline Ziekenhuizen & & \\
Psychiatrische ziekenhuizen & 16.900 & 2,1 \\
Verpleeghuizen & 4.200 & 2,2 \\
Gehandicaptenzorg & 10.700 & 2,1 \\
Gezinszorg & 3.500 & 1,5 \\
Kruiswerk & 40.900 & 3,2 \\
Bejaardenoorden & 4.300 & 1,9 \\
& 16.700 & 2,7 \\
Totaal & & 2,5
\end{tabular}

Bron: ROA

In de gezinszorg is de vervangingsvraag verhoudingsgewijs het grootst. In totaal moeten er in deze sector in de periode 1993-2005 ruim 40.000 arbeidsplaatsen door de arbeidsmarktinstroom van schoolverlaters worden opgevuld. Dit is een bijna even grote vervangingsbehoefte als in het Global Shift scenario. Evenals in Balanced Growth is de vervangingsvraag in het European Renaissance scenario vooral bij de intramurale sectoren veel geringer dan de vervan- 
$-86-$

gingsbehoefte in Global Shift. Daarbij ligt de vervangingsbehoefte aan schoolverlaters bij de ziekenhuizen, de psychiatrische ziekenhuizen en de verpleeghuizen net iets boven de $2 \%$ gemiddeld per jaar. Bij de gehandicaptenzorg is de vervangingsvraag net zoals in Balanced Growth nog kleiner, met een jaarlijks gemiddelde van 1,5\%. Naast de hogere participatiegraad die de vervangingsbehoefte aan schoolverlaters sterk drukt, is de lage vervangingsvraag in de intramurale sectoren ook toe te schrijven aan de geringere doorstroom van verpleegkundigen en ziekenverzorgenden naar beroepen buiten de zorgsector.

Vooral bij de bejaardenoorden is de vervangingsvraag in European Renaissance aanzienlijk groter dan in het Balanced Growth scenario. In totaal zullen in deze sector tot 2005 bijna 17.000 bestaande arbeidsplaatsen door schoolverlaters opnieuw moeten worden opgevuld. In het Balanced Growth scenario is er slechts een vervangingsbehoefte aan circa 10.000 schoolverlaters.

In tabel 7.4 wordt de in het European Renaissance scenario verwachte vervangingsvraag verbijzonderd naar beroepsgroep. Evenals in Balanced Growth is de vervangingsbehoefte met een jaarlijks gemiddelde van ruim $3 \%$ relatief het hoogst bij de helpenden. Al met al heeft bijna $40 \%$ van de totale vervangingsbehoefte in de zorgsector in European Renaissance betrekking op deze beroepsgroep. Bij de verzorgenden is de jaarlijkse vervangingsvraag gemiddeld bijna $3 \%$, een percentage dat aanmerkelijk hoger ligt dan de vervangingsbehoefte voor deze beroepsgroep in het Balanced Growth scenario.

Tabel 7.4. Vervangingsvraag naar schoolverlaters per beroepsgroep scenario European Renaissance 19932005 (totaal aantal en gemiddeld jaarlijks percentage)

\begin{tabular}{lcc} 
Beroepsgroep & aantal & $\%$ \\
\hline Verpleegkundigen & 28.700 & 2,0 \\
Ziekenverzorgenden & 13.900 & 2,1 \\
Verzorgenden & 17.800 & 2,9 \\
Helpenden & 36.800 & 3,3 \\
Totaal & 97.200 & 2,5 \\
\hline
\end{tabular}

Bron: ROA

Voor de verpleegkundigen en de ziekenverzorgenden is de vervangingsbehoefte aan schoolverlaters gemiddeld circa $2 \%$ per jaar. Dat is een iets hoger niveau dan de vervangingsvraag voor deze beroepsgroepen in Balanced Growth. Ook hier zijn de grote verschillen met de in het Global Shift scenario verwachte vervangingsvraag volledig toe te schrijven aan de hogere participatiegraad en de geringere doorstroom van arbeidskrachten naar beroepen buiten de zorgsector. 


\subsection{Baanopeningen}

In het European Renaissance scenario worden, zoals naar voren komt in tabel 7.5, tot 2005 in totaal ruim 200.000 baanopeningen voor schoolverlaters verwacht. Daarmee is de totale vraag naar schoolverlaters circa 35.000 personen hoger dan in Balanced Growth, maar ongeveer 90.000 personen lager dan in Global Shift. lets meer dan de helft van de baanopeningen vloeit voort uit de verwachte uitbreidingsvraag. Bij de psychiatrische ziekenhuizen, het kruiswerk en de bejaardenoorden is circa twee derde van het totaal aantal baanopeningen het gevolg van de werkgelegenheidstoename in deze deelsectoren. Bij het kruiswerk is het totaal aantal baanopeningen opvallend genoeg zelfs groter dan de totale vraag naar schoolverlaters in Global Shift. Dit heeft te maken met de hogere uitbreidingsvraag die in European Renaissance voor deze deelsector wordt verwacht, voortvloeiend uit de verschuiving van zorgvraag van zowel intramurale sectoren als bejaardenoorden naar het kruiswerk.

Tabel 7.5. Aantal baanopeningen en procentuele verdeling over uitbreidingsvraag en vervangingsvraag per deelsector scenario European Renaissance 1993-2005

\begin{tabular}{lccc}
\hline Deelsector & aantal & $\begin{array}{c}\text { uitbreidingsvraag } \\
\%\end{array}$ & $\begin{array}{c}\text { vervangingsvraag } \\
\%\end{array}$ \\
\hline & & & 81 \\
Ziekenhuizen & 21.000 & 79 & 30 \\
Psychiatrische ziekenhuizen & 14.200 & 63 & 37 \\
Verpleeghuizen & 29.200 & 48 & 52 \\
Gehandicaptenzorg & 6.700 & 46 & 54 \\
Gezinszorg & 75.600 & 67 & 33 \\
Kruiswerk & 12.900 & 61 & 39 \\
Bejaardenoorden & 42.700 & & 48 \\
Totaal & 202.300 & 52 & \\
\hline
\end{tabular}

Bron: ROA

Bij de gehandicaptenzorg en de gezinszorg is de verhouding tussen de vervangingsvraag en de uitbreidingsvraag min of meer fifty-fifty. Overigens doet een groot deel van het totaal aantal baanopeningen in de zorgsector zich voor in de gezinszorg. Tot 2005 gaat het daarbij om een totale vraag naar ruim 75.000 schoolverlaters. In de ziekenhuissector heeft het overgrote deel van de baanopeningen, net als bij Balanced Growth, betrekking op de vervangingsvraag. Gezien de geringe uitbreidingsvraag die in European Renaissance voor deze deelsector wordt verwacht, is dit niet verwonderlijk.

Tabel 7.6 geeft een overzicht van het totaal aantal baanopeningen in European Renaissance, verbijzonderd naar beroepsgroep. Voor de verpleegkundigen, de verzorgenden en de helpenden ligt het totaal aantal baanopeningen tot 2005 om en nabij de 55.000 arbeidsplaatsen. Voor de ziekenverzorgenden wordt een totale vraag naar schoolverlaters van ongeveer 35.000 verwacht. Bij de ziekenverzorgenden en de verzorgenden heeft het grootste deel van de baanopeningen betrekking op de uitbreidingsvraag. Daarentegen vloeien bij de verpleegkundigen 
en vooral ook bij de helpenden de meeste baanopeningen voort uit de vervangingsbehoefte aan schoolverlaters. Bij de helpenden is het totaal aantal baanopeningen in European Renaissance zelfs groter dan in Global Shift. Dit wordt veroorzaakt door de hogere uitbreidingsvraag als gevolg van de bovengenoemde overheveling van zorgtaken van dure naar goedkopere deelsectoren binnen de gezondheidszorg.

Tabel 7.6. Aantal baanopeningen en procentuele verdeling over uitbreidingsvraag en vervangingsvraag per beroepsgroep scenario European Renaissance 1993-2005

\begin{tabular}{lccc}
\hline Beroepsgroep & aantal & $\begin{array}{c}\text { uitbreidingsvraag } \\
\%\end{array}$ & $\begin{array}{c}\text { vervangingsvraag } \\
\%\end{array}$ \\
\hline Verpleegkundigen & 55.400 & 48 & 52 \\
Ziekenverzorgenden & 35.700 & 61 & 39 \\
Verzorgenden & 52.800 & 66 & 34 \\
Helpenden & 58.400 & 37 & 63 \\
Totaal & 202.300 & 52 & 48 \\
\hline
\end{tabular}

Bron: ROA

De beroepsgroep ziekenverzorgende is de enige waarvoor het totaal aantal baanopeningen in European Renaissance niet hoger ligt dan in Balanced Growth. Daarbij valt de ietwat hogere vervangingsvraag in European Renaissance weg tegen een lagere uitbreidingsvraag dan in Balanced Growth. Bij de verpleegkundigen is het totaal aantal baanopeningen in European Renaissance weliswaar bijna 8.000 arbeidsplaatsen groter dan in Balanced Growth, maar desalniettemin is de totale vraag naar schoolverlaters nog niet de helft van die in het Global Shift scenario.

Tabel 7.7 geeft een overzicht van het totaal aantal baanopeningen tot 2005, verbijzonderd naar deelsector en beroep. Voor verpleegkundigen zijn de meeste baanopeningen te vinden in de ziekenhuizen en, zij het in veel mindere mate, in de psychiatrische ziekenhuizen. In vrijwel alle sectoren is het aantal baanopeningen voor verpleegkundigen gelijk aan of groter dan de totale vraag naar schoolverlaters met een opleiding tot verpleegkundige in de desbetreffende sectoren in Balanced Growth. De enige uitzondering wordt wat dit betreft gevormd door de psychiatrische ziekenhuizen, waar het aantal baanopeningen voor verpleegkundigen maar liefst 3.000 arbeidsplaatsen achterblijft bij de totale vraag in deze sector in Balanced Growth.

Vergeleken met het Global Shift scenario is het aantal baanopeningen voor verpleegkundigen en ziekenverzorgenden in European Renaissance in vrijwel alle sectoren veel geringer. Alleen in het kruiswerk ligt het aantal baanopeningen voor verpleegkundigen en ziekenverzorgenden boven het niveau van de totale vraag naar schoolverlaters in Global Shift. Dit hangt samen met de bovengenoemde verschuivingen in de zorgvraag van duurdere deelsectoren naar deze relatief goedkope vorm van zorgverlening. 
$-89-$

Bij de verzorgenden is het aantal baanopeningen het grootst in de bejaardenoorden en de gezinszorg. Vooral in de gezinszorg ligt het aantal baanopeningen voor deze beroepsgroep in European Renaissance aanmerkelijk hoger dan in Balanced Growth. In beide deelsectoren is de totale vraag naar schoolverlaters aanmerkelijk geringer dan in Global Shift. Bij de helpenden doet zich vrijwel hetzelfde beeld voor. Het meest opvallend is hier het grote aantal baanopeningen in de gezinszorg. In deze deelsector worden bij European Renaissance maar liefst bijna 54.000 baanopeningen voor helpenden verwacht, tegenover nog geen 40.000 in Balanced Growth en circa 49.000 in Global Shift.

Tabel 7.7. Aantal baanopeningen verbijzonderd naar deelsector en beroepsgroep scenario European Renaissance 1993-2005

\begin{tabular}{|c|c|c|c|c|}
\hline Deelsector & $\begin{array}{l}\text { verpleeg- } \\
\text { kundigen }\end{array}$ & $\begin{array}{l}\text { Beroepsgroep } \\
\text { zieken- } \\
\text { verzorgenden }\end{array}$ & verzorgenden & helpenden \\
\hline Ziekenhuizen & 22.200 & 800 & - & - \\
\hline Psychiatrische ziekenhuizen & 12.200 & 2.100 & - & - \\
\hline Verpleeghuizen & 5.500 & 23.600 & - & - \\
\hline Gehandicaptenzorg & 6.500 & 200 & - & - \\
\hline Gezinszorg & - & - & 21.700 & 53.900 \\
\hline Kruiswerk & 6.500 & 3.000 & 3.400 & - \\
\hline Bejaardenoorden & 2.600 & 7.800 & 27.700 & 4.500 \\
\hline
\end{tabular}

Bron: ROA

\subsection{Instroom van schoolverlaters}

Tegenover het in European Renaissance in vergelijking met het Balanced Growth scenario grotere aantal baanopeningen staat ook een groter aanbod van schoolverlaters. Uit tabel 7.8 blijkt dat in de jaren 1993-2005 in totaal bijna 195.000 schoolverlaters op de arbeidsmarktsegmenten voor de zorgsector zullen instromen. Dit stemt overeen met een gemiddelde jaarlijkse instroom van $4,5 \%$. De arbeidsmarktinstroom van schoolverlaters in European Renaissance is daarmee ruim 20.000 groter dan in Balanced Growth en zelfs bijna $\mathbf{3 5 . 0 0 0}$ meer dan in Global Shift.

Evenals bij beide andere scenario's is de instroom van schoolverlaters in European Renaissance verhoudingsgewijs het grootst bij de verzorgenden. Het instroompercentage voor deze beroepsgroep is maar liefst $6,5 \%$. Deze hoge arbeidsmarktinstroom op dit beroepssegment is vooral het gevolg van het toenemende aantal jongeren dat een duaal opleidingstraject volgt. Met name jongens zullen in toenemende mate deze opleidingen gaan volgen. Ook bij de helpenden is de arbeidsmarktinstroom met een jaarlijks gemiddelde van bijna $5 \%$ relatief hoog. In totaal gaat het daarbij om een arbeidsmarktinstroom van maar liefst 58.000 schoolverlaters, tegenover slechts 8.000 in Global Shift en bijna 43.000 in Balanced Growth. Deze veel hogere arbeidsmarktinstroom van schoolverlaters op dit arbeidsmarktsegment is in European Renaissance 
vooral het gevolg van de omvangrijke om- en bijscholingsactiviteiten van de Arbeidsvoorzieningsorganisatie en de bestaande Jeugdwerkgarantieregelingen en banenpools, waarvan veel jongeren gebruik maken.

Tabel 7.8. Instroom van schoolverlaters per beroepsgroep scenario European Renaissance 1993-2005 (totaal aantal en gemiddeld jaarlijks percentage)

\begin{tabular}{lcc} 
Beroepsgroep & aantal & $\%$ \\
\hline Verpleegkundigen & 52.500 & 3,4 \\
Ziekenverzorgenden & 33.100 & 4,4 \\
Verzorgenden & 50.400 & 6,5 \\
Helpenden & 58.400 & 4,8 \\
Totaal & 194.500 & 4,5
\end{tabular}

Bron: ROA

In tegenstelling tot de ontwikkeling van de instroom van verzorgenden en helpenden in de zorgsector, ligt de arbeidsmarktinstroom bij ziekenverzorgenden iets onder het gemiddelde en daarmee ook net iets onder de instroom van schoolverlaters op dit beroepssegment in de beide andere scenario's. Bij de verpleegkundigen bedraagt de instroom van schoolverlaters gemiddeld slechts $3,4 \%$ per jaar, een percentage dat vrijwel gelijk is aan het instroompercentage voor verpleegkundigen in Balanced Growth, maar duidelijk lager ligt dan het binnen het Global Shift scenario verwachte percentage. Evenals in Balanced Growth is dit vooral het gevolg van het afsluiten van de mogelijkheid voor MAVO-opgeleiden om direct in te stromen in de inserviceopleidingen voor het hoogste deskundigheidsniveau. Daarnaast is de arbeidsmarktinstroom vanuit het HBO-V lager, vanwege de grotere belangstelling van vooral meisjes voor het volgen van onderwijs op wetenschappelijk niveau.

\subsection{Toekomstige arbeidsmarktsituatie}

Uit de confrontatie van vraag en aanbod op de verschillende arbeidsmarktsegmenten blijkt dat er per saldo in European Renaissance bij de meeste beroepsgroepen sprake is van geringe aanbodtekorten. Uit tabel 7.9 blijkt dat in 2005 er bij de ziekenverzorgenden sprake is van een tekort aan arbeidskrachten van bijna $4 \%$, een tekort van circa 2.500 personen. Dit tekort is weliswaar slechts een fractie van de in het Global Shift scenario voor deze beroepsgroep verwachte tekort, maar desalniettemin kan het tot knelpunten leiden bij de werving van personeel. Waarschijnlijk zullen vooral de verpleeghuizen, die het grootste marktaandeel hebben op dit arbeidsmarktsegment, hiervan de meeste hinder ondervinden.

Ook bij de verzorgenden schiet de arbeidsmarktinstroom tekort om het totaal aantal baanopeningen voor schoolverlaters op te kunnen vullen. Voor 2005 wordt al met al een tekort van bijna 2.500 arbeidskrachten verwacht, hetgeen betekent dat circa $3 \%$ van het totaal aantal 
arbeidsplaatsen niet kan worden vervuld. Verwacht mag worden dat vooral de bejaardenoorden en de gezinszorg door dit tekort problemen zullen ondervinden bij hun personeelsvoorziening, al kan ook hierbij worden opgemerkt dat het tekort veel geringer is dan in het Global Shift scenario.

Tabel 7.9. Aanbodoverschot of -tekort per beroepsgroep scenario European Renaissance in 2005 (totaal aantal en relatief ten opzichte van de verwachte vraag in 2005)

\begin{tabular}{lrr}
\hline Beroepsgroep & aantal & $\%$ \\
\hline Verpleegkundigen & -2.900 & $-2,2$ \\
Ziekenverzorgenden & -2.500 & $-3,6$ \\
Verzorgenden & -2.400 & $-3,0$ \\
Helpenden & 0 & 0,0 \\
Totaal & -7.800 & $-2,0$ \\
\hline
\end{tabular}

Bron: ROA

Voor de verpleegkundigen wordt in 2005 een aanbodtekort verwacht van ruim $2 \%$ van de totale werkgelegenheid voor verpleegkundigen op dat moment. Dit zou vooral in de ziekenhuizen tot wervingsproblemen kunnen leiden. Bij de helpenden wordt in European Renaissance, evenals in Balanced Growth, verwacht dat vraag en aanbod op de arbeidsmarkt redelijk met elkaar in evenwicht zullen zijn, als gevolg van het met name curatieve, maar deels ook preventieve beleid van de Arbeidsvoorzieningsorganisatie op basis waarvan een aanzienlijk aantal jongeren worden doorgesluisd naar de lagere functies in de zorgsector. 


\section{DE DRIE SCENARIO'S SAMENGEVAT}

\subsection{Inleiding}

In de drie voorgaande hoofdstukken is per scenario ingegaan op de ontwikkelingen aan zowel de vraagzijde als de aanbodzijde van de arbeidsmarkt in de zorgsector. Dit hoofdstuk vat de drie scenario's in kwantitatieve zin samen. Daarbij wordt dezelfde opbouw gehanteerd als in de voorgaande hoofdstukken: uitbreidingsvraag, vervangingsvraag, aantal baanopeningen, instroom van schoolverlaters en ten slotte de uit deze toekomstige stromen resulterende arbeidsmarktsituatie in 2005.

In het Global Shift scenario, dat ook wel als het 'doormodder'-scenario wordt gekenschetst, vinden er geen belangrijke beleidswijzigingen in de zorgsector plaats. Het huidige groeipatroon van het gebruik van de zorgvoorzieningen wordt daarbij tot aan 2005 voortgezet. $\mathrm{Er}$ is in Global Shift geen sprake van efficiency-verbeteringen. Op de arbeidsmarkt blijven de bestaande rigiditeiten in stand. Er zijn derhalve weinig extra prikkels voor inactieven om zich op de arbeidsmarkt aan te bieden.

Balanced Growth gaat er daarentegen van uit dat er een aanzienlijke efficiency-verbetering in de zorgsector optreedt. Dit wordt onder meer bewerkstelligd door een besparing in de intramurale zorgverlening als gevolg van een voortgaande technologische ontwikkeling. Ook door de invoering van 'managed care' systemen kan er in de intramurale zorg een besparing op de personeelskosten worden bereikt. In de extramurale sectoren neemt de werkgelegenheid af door aanzienlijke verhogingen van eigen bijdragen in de extramurale gezondheidszorg. De opbouw van woon-zorg-complexen levert een aanzienlijke besparing in de bejaardenoorden op. Verder wordt er door substitutie van de zorgverlening van de intramurale naar de extramurale sectoren een forse besparing bereikt.

De belemmeringen op de arbeidsmarkt worden in Balanced Growth afgebouwd. Dit leidt tot een forse toename van het aantal herintreders, waardoor de behoefte aan schoolverlaters geringer wordt. Bovendien wordt hierdoor de tussentijdse uitstroom van arbeidskrachten uit de zorgsector aanzienlijk teruggebracht. De studie- en beroepskeuze van scholieren wordt in dit scenario meer marktconform. In het algemeen kan worden gesteld dat het opleidingsniveau van de beroepsbevolking hoger wordt. Verder wordt de doorstroommogelijkheid van scholieren van MAVO naar Inservice-A, -B of $-Z$, als ook van VBO-gediplomeerden naar Inservice-ZV opgeheven.

Ook in het European Renaissance scenario wordt er in de zorgsector een aanzienlijke efficiencywinst bewerkstelligd. In het kader van de basisverzekering bij het nieuwe stelsel voor de gezondheidszorg wordt door de overheid een kostenbesparend programma doorgevoerd. Daarbij kan worden gedacht aan 'managed care' systemen en 'utilization review'. Verder is er in dit scenario, meer dan nog in Balanced Growth, sprake van verplaatsing van zorg van de intramurale naar de extramurale sectoren: de intramurale zorgsectoren verliezen daarbij in belangrijke 
mate hun hotelfunctie. Ten slotte wordt ook door de technologische ontwikkeling een verdergaande daling van het gemiddeld aantal ligdagen bewerkstelligd. Dit zet echter minder zoden aan de dijk dan in het Balanced Growth scenario.

De participatie van vooral vrouwen neemt in European Renaissance fors toe. De toename van de participatiegraad is echter minder groot dan in het Balanced Growth scenario. Toch is er in European Renaissance sprake van een aanzienlijke toename van het aantal herintreders in de zorgsector, terwijl het aantal arbeidskrachten dat tussentijds uit de zorgsector stroomt aanzienlijk afneemt. Evenals in Balanced Growth gaat het gemiddelde opleidingsniveau van de beroepsbevolking omhoog. Verder groeit de studiekeuze van jongens en meisjes meer naar elkaar toe. Een belangrijke rol is in dit scenario weggelegd voor de Arbeidsvoorzieningsorganisatie. Met behulp van de ter beschikking staande scholingsinstrumenten en bijvoorbeeld het Jeugdwerkgarantieplan en banenpools wordt een aanzienlijke instroom in de beroepsgroepen verzorgende en helpende bewerkstelligd.

\subsection{Uitbreidingsvraag}

Figuur 8.1. Uitbreidingsvraag per deelsector en scenario 1993-2005

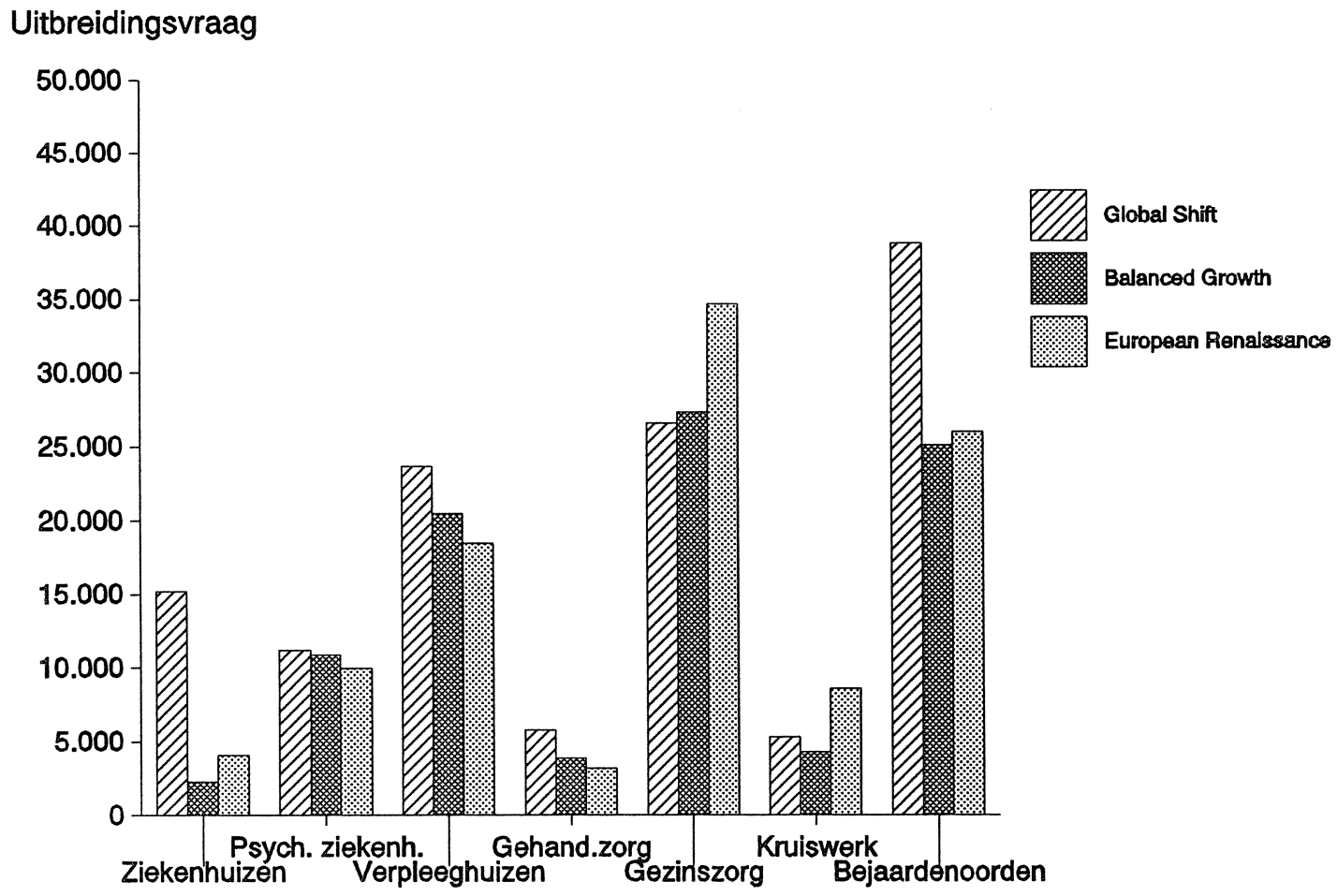

Bron: ROA

Door de, mede als gevolg van de demografische ontwikkeling, voortdurende groei van de zorgvraag en het ontbreken van kostenbesparende beleidsmaatregelen is in het Global Shift scenario de werkgelegenheidsgroei het hoogst. Uit figuur 8.1 blijkt dat in dit scenario vooral in 
de deelsectoren binnen de intramurale zorgverlening en in de sector bejaardenoorden de uitbreidingsvraag relatief groot is. Een typerend voorbeeld is de sector ziekenhuizen. Terwijl in Global Shift de vraag naar arbeidskrachten met 15.000 toeneemt, blijft de werkgelegenheidsgroei in de beide andere scenario's beperkt tot minder dan 5.000 personen. In Balanced Growth is de uitbreidingsvraag daarbij nog lager dan in European Renaissance.

In de drie andere deelsectoren binnen de intramurale zorg is de werkgelegenheidsgroei in het European Renaissance scenario het laagst. Dit hangt samen met de in dit scenario beter van de grond komende extramuralisering van de gezondheidszorg. Het blijkt dan ook dat de werkgelegenheid in de gezinszorg en het kruiswerk in dit scenario fors toeneemt. Voor deze sectoren is de werkgelegenheidsgroei in European Renaissance zelfs nog groter dan in Global Shift.

Figuur 8.2. Uitbreidingsvraag per beroepsgroep en scenario 1993-2005

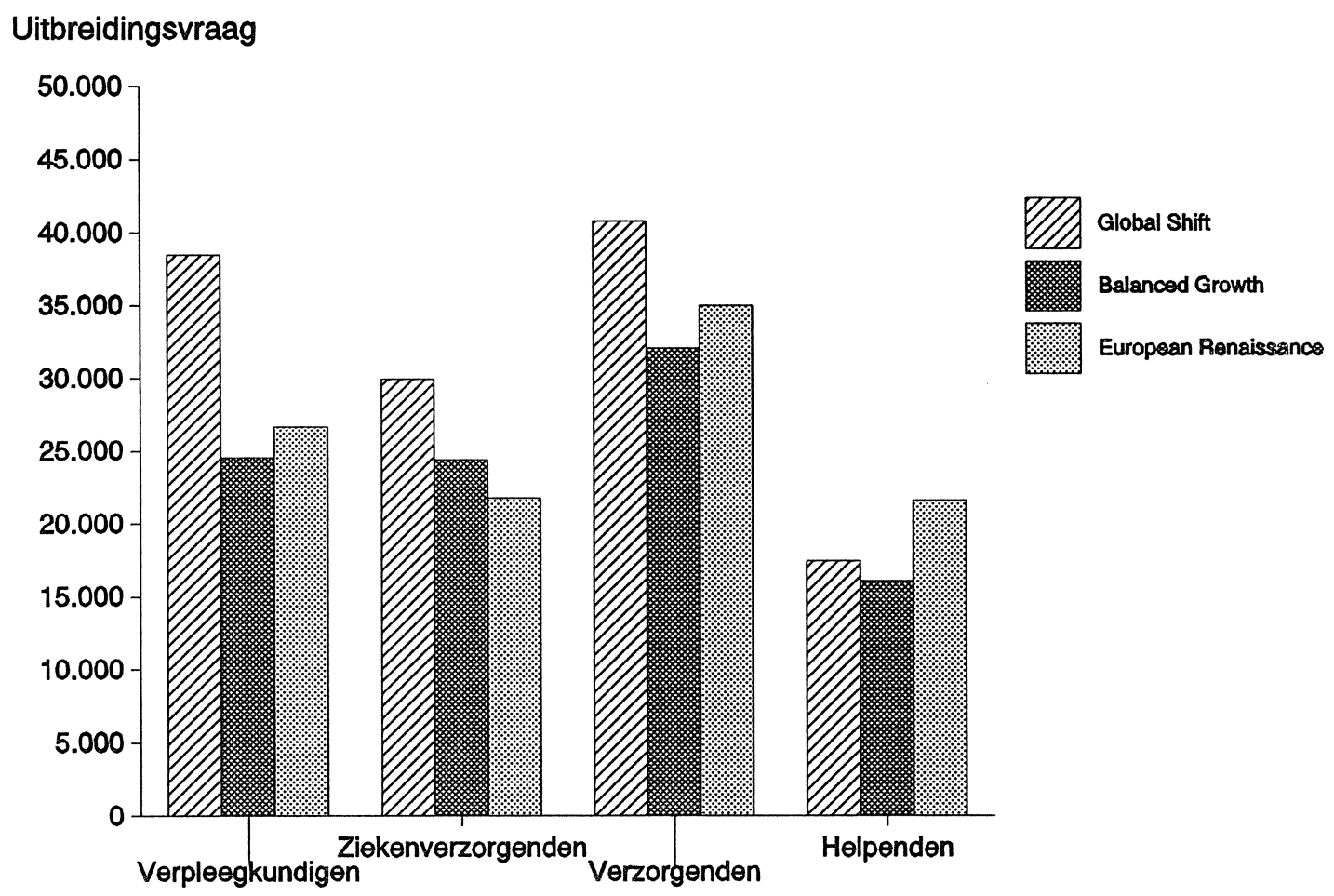

Bron: ROA

Figuur 8.2 laat zien dat de groei van de werkgelegenheid voor verpleegkundigen, ziekenverzorgenden en verzorgenden het grootst is in het Global Shift scenario. In European Renaissance is als gevolg van de vooral in dit scenario doorgevoerde extramuralisering de uitbreidingsvraag naar ziekenverzorgenden het laagst. Daar staat echter tegenover dat er in dit scenario sprake is van een aanzienlijke uitbreidingsvraag naar helpenden. Ondanks de hoge werkgelegenheidsgroei voor verzorgenden in de gezinszorg in European Renaissance is de totale uitbreidingsvraag voor verzorgenden in het Global Shift scenario nog groter. Dit hangt vooral samen met de in dit laatstgenoemde scenario sterk groeiende werkgelegenheid in de bejaardenoorden. 


\subsection{Vervangingsvraag}

De door het CPB aangegeven verschillen in de ontwikkeling van de participatiegraad vormen een goede afspiegeling van de vervangingsvraag naar schoolverlaters in de drie lange-termijn scenario's. Figuur 8.3 geeft een overzicht van de vervangingsvraag in de periode 1993-2005, verbijzonderd naar deelsector. In figuur $\mathbf{8 . 4}$ wordt de vervangingsvraag naar schoolverlaters per beroepsgroep gepresenteerd. De vervangingsvraagramingen zijn daarbij 'gecorrigeerd' voor de te verwachten instroom van herintreders, hetgeen betekent dat de in beide figuren gepresenteerde vervangingsbehoefte, alsmede de uitbreidingsvraag, door schoolverlaters moet worden opgevangen.

Figuur 8.3. Vervangingsvraag naar schoolverlaters per deelsector en scenario 1993-2005

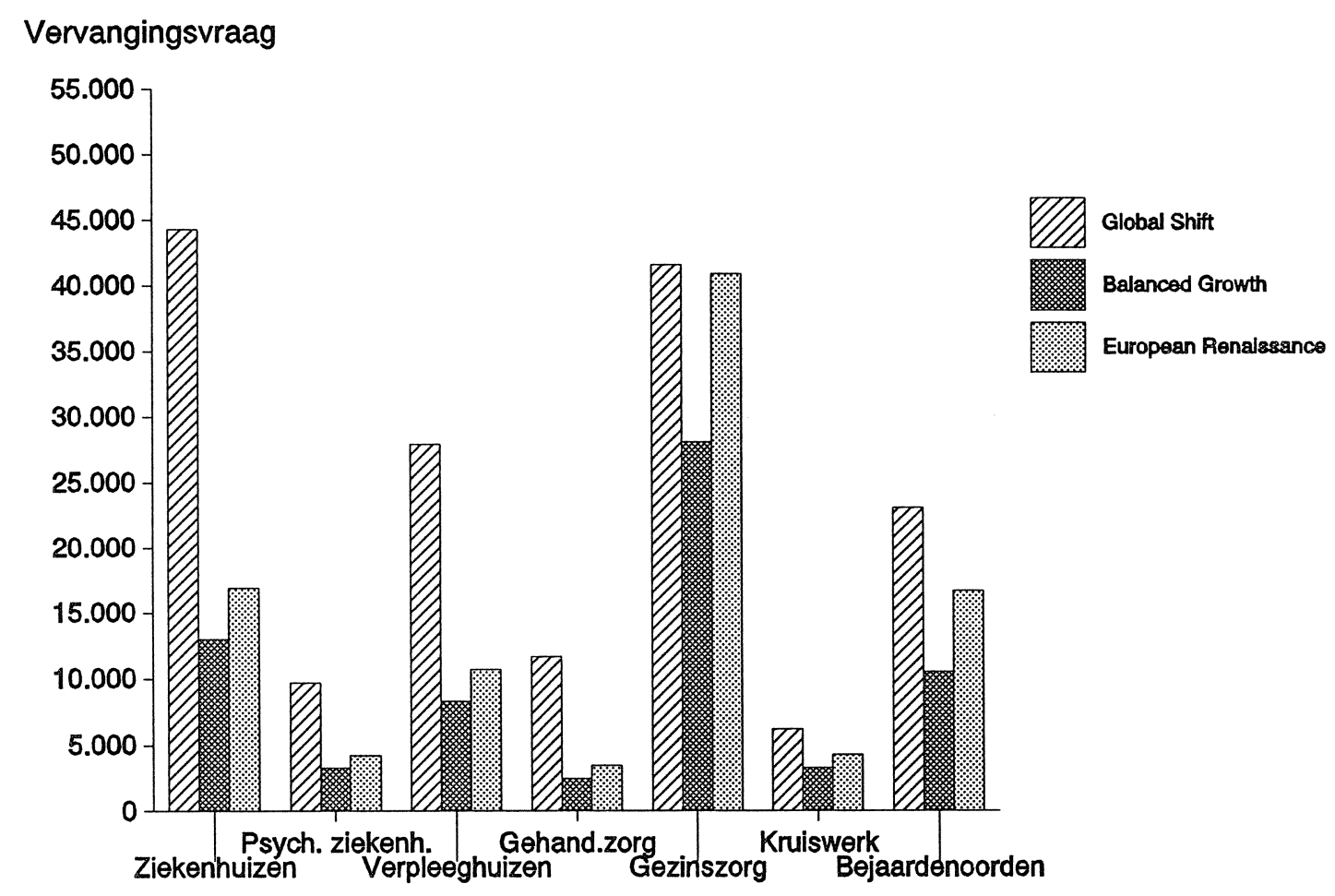

Bron: ROA

De rangorde in hoogte van de vervangingsvraag - Global Shift, European Renaissance en Balanced Growth - geldt voor elke onderscheiden deelsector. Het verschil in vervangingsvraag tussen Balanced Growth en European Renaissance is in het algemeen echter gering. Een opvallende uitzondering op dit punt is de sector gezinszorg en in mindere mate de bejaardenoorden. In deze sectoren is de vervangingsvraag naar zowel de verzorgenden als helpenden in European Renaissance in vergelijking met Balanced Growth hoog. De totale vervangingsbehoefte aan schoolverlaters voor de beroepsgroep verzorgenden is in European Renaissance zelfs nog hoger dan in het Global Shift scenario. 
Figuur 8.4. Vervangingsvraag naar schoolverlaters per beroepsgroep en scenario 1993-2005

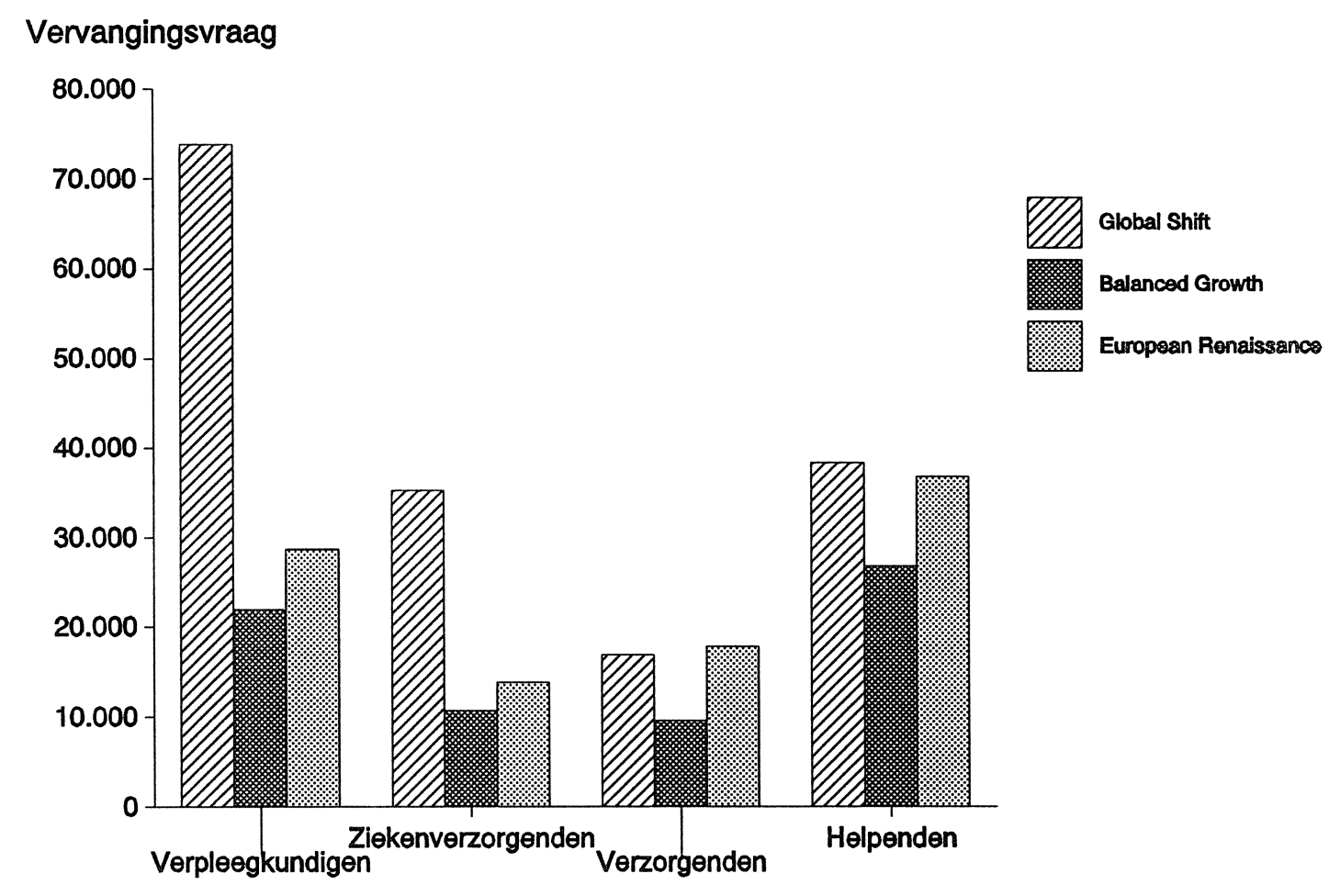

Bron: ROA

\subsection{Baanopeningen}

De uitbreidingsvraag en de vervangingsvraag vormen samen het totaal aantal baanopeningen, oftewel de totale vraag naar schoolverlaters. Figuur 8.5 laat zien dat in de sector gezinszorg het aantal baanopeningen in de periode 1993-2005 het grootst zal zijn. Dit geldt voor alle drie de scenario's. In het European Renaissance scenario is het aantal baanopeningen in deze sector het grootst. Ook bij het kruiswerk blijkt binnen het European Renaissance scenario de grootste totale vraag naar schoolverlaters te bestaan.

Voor de overige deelsectoren binnen de zorgsector geldt dat het aantal baanopeningen in het Global Shift scenario het hoogst is. Zowel de uitbreidingsvraag als de vervangingsvraag zijn in dit scenario relatief hoog. In de intramurale zorgverlening is er, met uitzondering van de sector ziekenhuizen, weinig verschil in de totale vraag naar schoolverlaters tussen de Balanced Growth en European Renaissance scenario's. In Balanced Growth is de vervangingsvraag iets lager, maar daar staat tegenover dat de uitbreidingsvraag weer iets hoger ligt. Voor de sector ziekenhuizen wordt er in Balanced Growth door de diffusie van nieuwe produktiviteitsverhogende technieken als endoscopische chirurgie van uitgegaan dat er een grotere besparing van het aantal ligdagen kan worden bewerkstelligd, waardoor er in de - als gevolg van de demografische druk - sterk toenemende zorgbehoefte, met nauwelijks meer verpleegkundigen en ziekenverzorgenden kan worden voorzien. 
$-97-$

Figuur 8.5. Aantal baanopeningen per deelsector en scenario 1993-2005

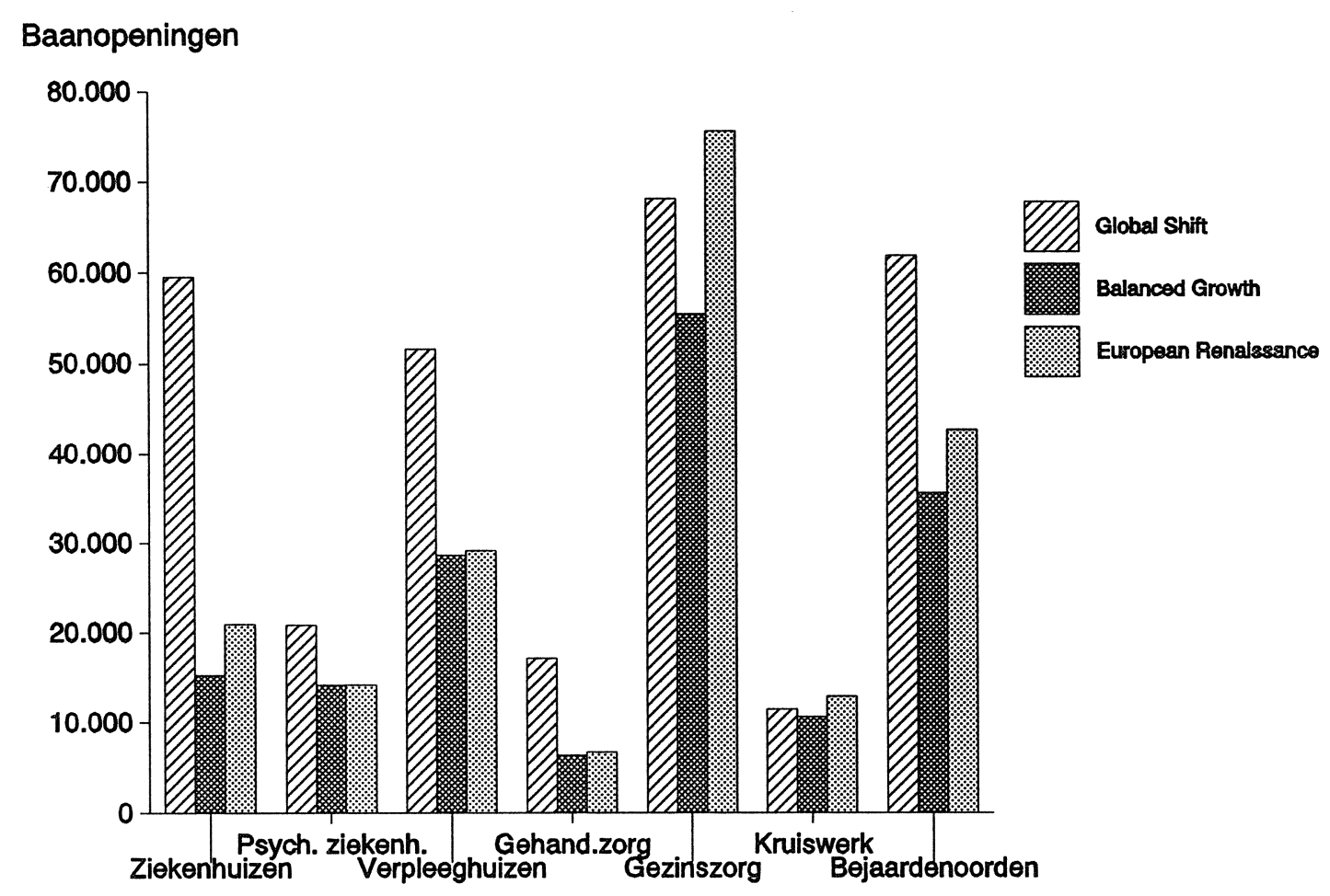

Bron: ROA

Figuur 8.6. Aantal baanopeningen per beroepsgroep en scenario 1993-2005

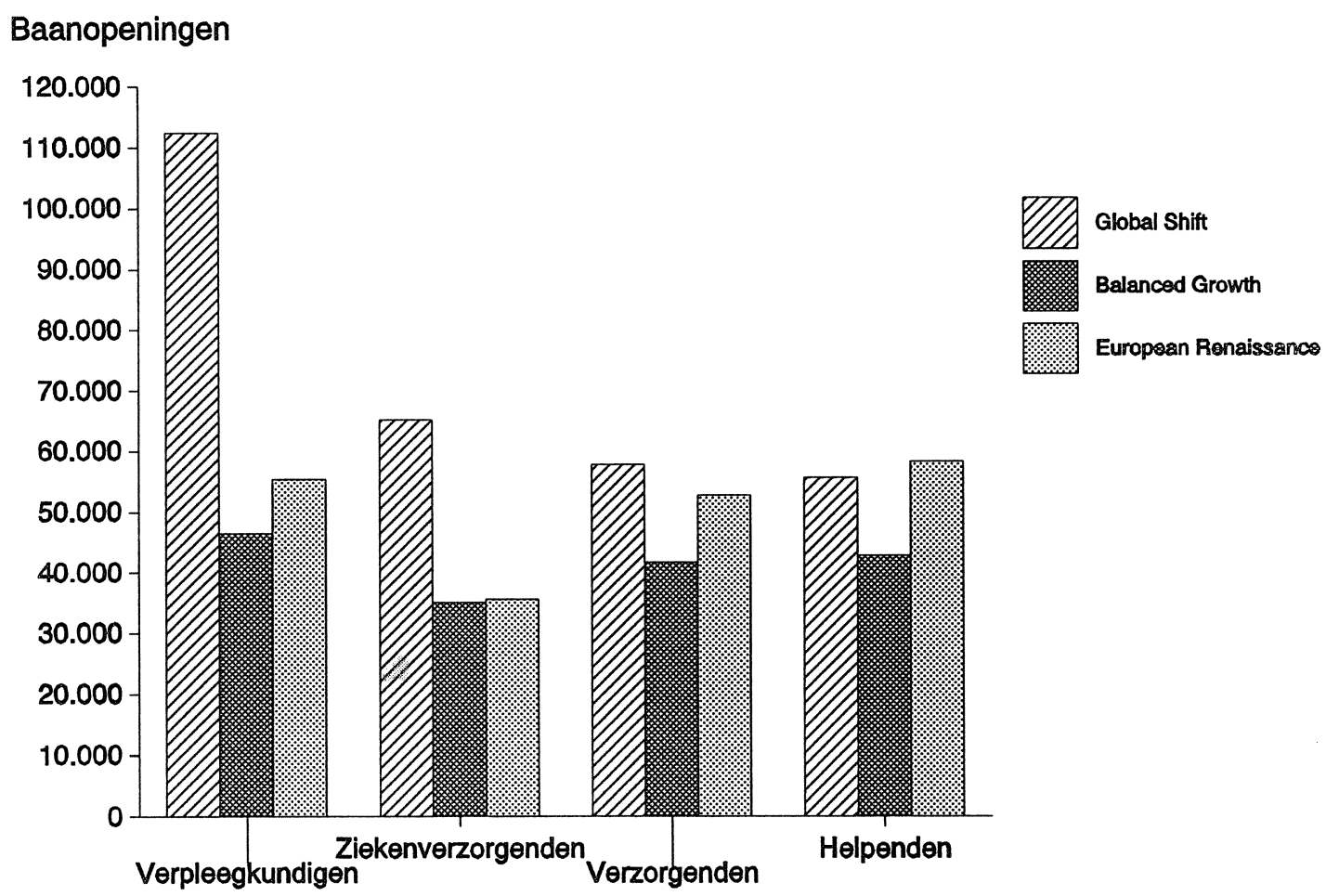


Figuur 8.6 geeft per scenario aan hoe groot het aantal baanopeningen in de periode 1993-2005 per beroepsgroep zal zijn. In het Global Shift scenario is er een totale vraag naar schoolverlaters met een opleiding tot verpleegkundige van meer dan 110.000 personen. Dit is maar liefst meer dan twee maal zo veel als in de beide andere scenario's. Ook ten aanzien van de totale vraag naar ziekenverzorgenden blijkt dat deze in Global Shift meer dan twee maal groter is dan in Balanced Growth en European Renaissance. Voor de verzorgenden en helpenden zijn de verschillen tussen de scenario's gering. Het totaal aantal baanopeningen voor deze beroepsgroepen is het laagst bij Balanced Growth.

\subsection{Instroom van schoolverlaters}

In zowel het Balanced Growth als het European Renaissance scenario neemt het gemiddeld opleidingsniveau van de schoolverlaters fors toe, deels ook als gevolg van het sterk verminderen van inefficiënte leerroutes. Zo neemt de doorstroom HAVO-MBO af ten gunste van de 'koninklijke' leerroute HAVO-HBO. Het belangrijkste kenmerk van Balanced Growth is echter dat de studie- en beroepskeuze van jongeren, mede door een adequate voorlichting over toekomstige arbeidsmarktperspectieven, meer marktconform wordt. Ook in European Renaissance is er sprake van meer marktconformiteit. Deze wordt echter in sterkere mate dan bij Balanced Growth bereikt door aanvullende scholingsmaatregelen van de Arbeidsvoorzieningsorganisatie.

Figuur 8.7. Instroom van schoolverlaters per beroepsgroep en scenario 1993-2005

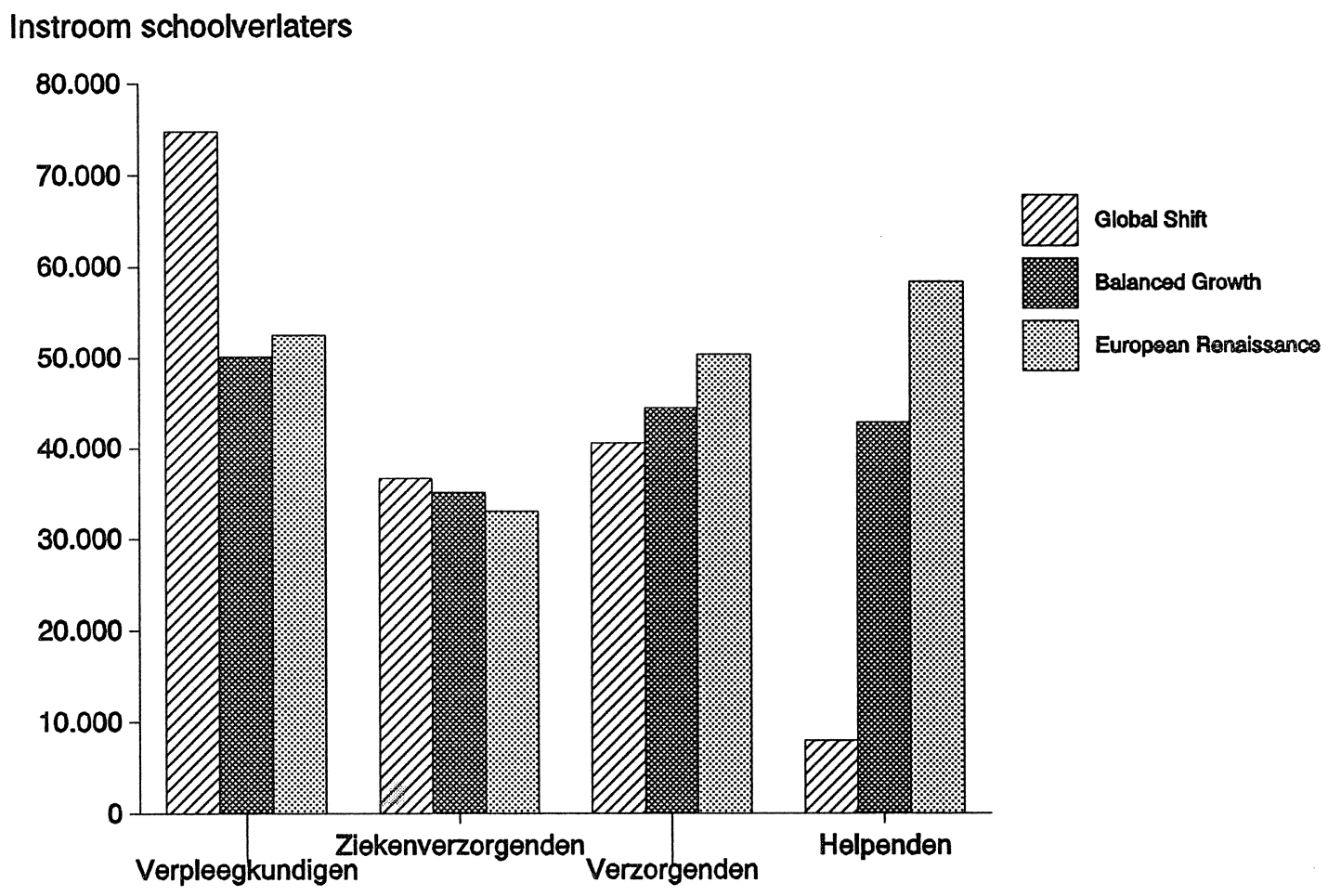


Figuur 8.7 geeft per beroepsgroep een overzicht van de instroom van schoolverlaters in de periode 1993-2005 volgens de drie scenario's. De instroom van schoolverlaters met een opleiding tot verpleegkundige is het grootst in het Global Shift scenario. Ongeveer 75.000 verpleegkundigen stromen in dit scenario in op de arbeidsmarkt. De jongeren zijn in Balanced Growth en European Renaissance goed op de hoogte van de afnemende werkgelegenheidsgroei voor verpleegkundigen en de voor deze beroepsgroep vanwege het geringere personeelsverloop veel lagere vervangingsvraag naar schoolverlaters. De arbeidsmarktinstroom is in deze scenario's daarom respectievelijk ongeveer 25.000 en 23.000 personen lager dan in Global Shift.

De instroom van ziekenverzorgenden ligt in alle drie de scenario's min of meer op hetzelfde niveau. Bij de verzorgenden en helpenden is er wel sprake van aanzienlijke verschillen in de instroom van schoolverlaters. Het meest duidelijk is dat bij de helpenden. Vooral in het European Renaissance scenario wordt een forse toename van de instroom voor beide beroepsgroepen voorspeld, waardoor het aanbod in evenwicht komt met de voorspelde totale vraag. Dit komt vooral door de hogere instroom en de hogere slaagpercentages in het leerlingwezen. Ook de aanvullende scholingsmaatregelen van de Arbeidsvoorzieningsorganisatie hebben in dit scenario succes. De toenemende instroom van verzorgenden hangt in Balanced Growth vooral samen met een hogere doorstroom van VBO-leerlingen naar het DGO. Ook is er in dit scenario, evenals overigens in European Renaissance, sprake van een forse rendementsverbetering bij het leerlingwezen. De arbeidsmarktinstroom van helpenden is in het Balanced Growth scenario geheel in evenwicht met het verwachte aantal baanopeningen.

\subsection{Toekomstige arbeidsmarktsituatie}

De voor de drie scenario's verwachte arbeidsmarktsituatie in 2005 wordt weergegeven in figuur 8.8. Daarbij wordt de arbeidsmarktsituatie voor de beroepsgroep helpende buiten beschouwing gelaten. In Balanced Growth en European Renaissance komt het aanbod van helpenden, zoals gezegd, geheel overeen met de vraag. Voor het Global Shift scenario wordt weliswaar een veel te geringe 'ex ante' instroom vanuit de opleidingen verwacht, maar gezien de erg ruime arbeidsmarkt voor lager opgeleiden mag ook in dit scenario worden aangenomen dat er op dit arbeidsmarktsegment, mede gezien de minder stringente opleidingseisen, slechts weinig recruteringsproblemen zullen ontstaan.

Uit de figuur blijkt duidelijk dat de arbeidsmarkt in de zorgsector bij het Global Shift scenario volledig vastloopt. De tekorten aan verpleegkundigen, ziekenverzorgenden en verzorgenden nemen in dit doormodder-scenario een enorme omvang aan. Opvallend genoeg doen deze personeelstekorten in de zorgsector zich voor bij een in het algemeen in dit scenario zeer ruime arbeidsmarkt. Zoals ook in de jaren tachtig reeds is gebleken, is een dergelijke 'mismatch' tussen vraag en aanbod bij de beroepsgroepen in de zorgsector waarvoor strikte opleidingseisen bestaan, doorgaans moeilijk op basis van een curatief beleid op korte termijn te bestrijden. Dit betekent dat vrijwel alle deelsectoren binnen de zorg te kampen krijgen met aanzienlijke recruteringsproblemen bij de werving van nieuw personeel. Hierdoor zal aan een deel van de zorgbehoefte niet kunnen worden voldaan. Binnen de verschillende zorgvoorzieningen zal 
daarom een prioritering moeten worden aangebracht. Bovendien zal door de grote personeelstekorten de werkdruk in de zorgsectoren verder toenemen. De arbeidsonrust in de zorgsector die daarvan het gevolg is, zal een opwaartse druk op de lonen bewerkstelligen. Hierdoor treedt er in de verschillende zorgsectoren een verdere prijsstijging op.

Figuur 8.8. Aanbodoverschot of -tekort per beroepsgroep en scenario in 2005

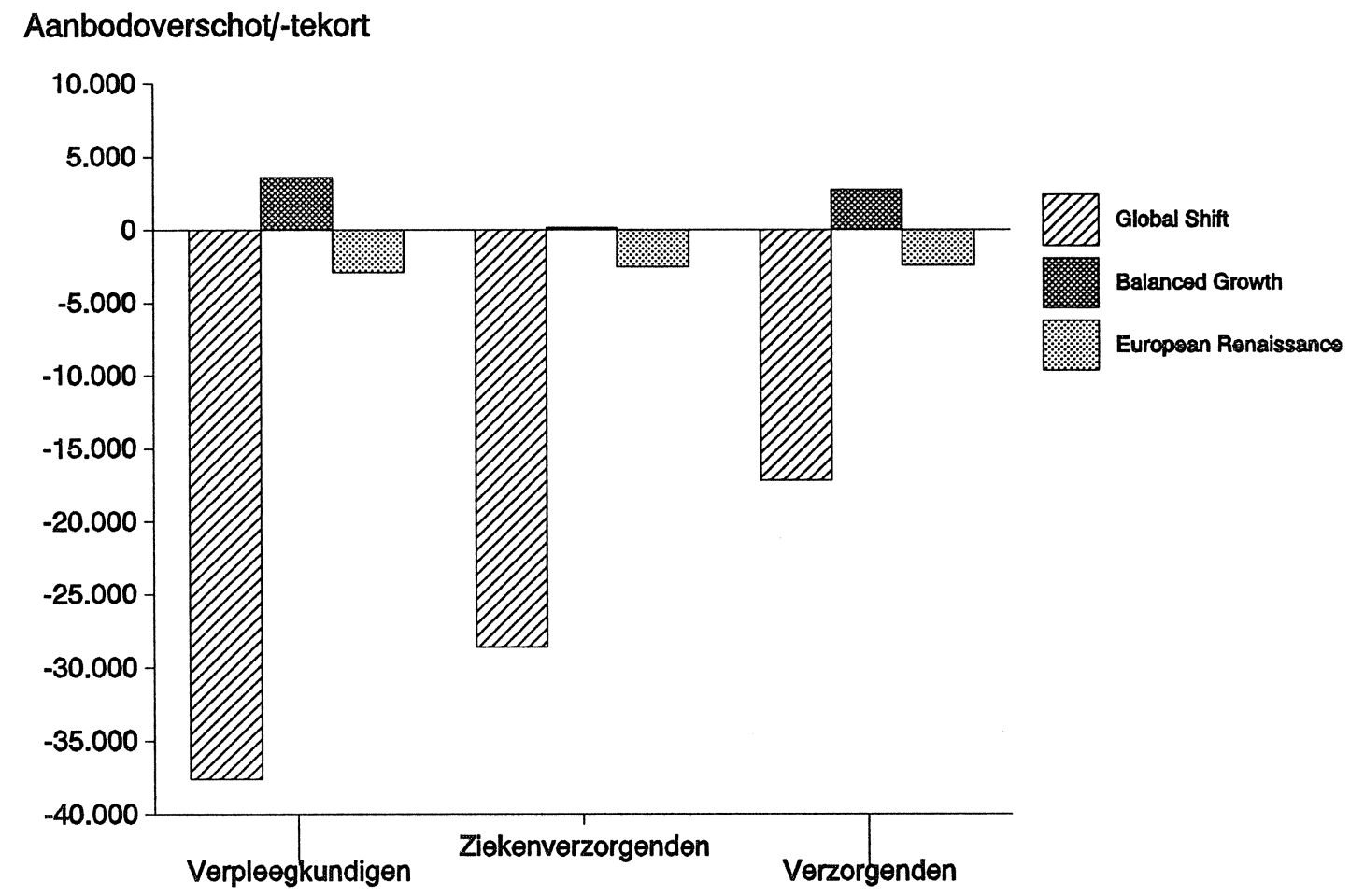

Bron: ROA

Bij het Balanced Growth scenario is er in 2005 sprake van een min of meer evenwichtige situatie op de arbeidsmarktsegmenten in de zorgsector. De in de figuur aangegeven lichte aanbodoverschotten zijn nauwelijks groter dan op grond van arbeidsmarktfricties mag worden verwacht. Het overschot aan ziekenverzorgenden is zelfs vrijwel nihil. Daardoor zullen er hier en daar enige spanningen op de arbeidsmarkt kunnen ontstaan. Met name de sector verpleeghuizen, waar ongeveer $60 \%$ van de ziekenverzorgenden werkzaam is en waar bovendien de vraag naar schoolverlaters verhoudingsgewijs hoog is, zal worden geconfronteerd met knelpunten in de personeelsvoorziening.

Het European Renaissance scenario wordt gekenmerkt door geringe tekorten voor de drie onderscheiden beroepsgroepen in de zorgsector. Door de overheid en de Arbeidsvoorzieningsorganisatie wordt weliswaar een curatief en deels ook preventief arbeidsmarktbeleid gevoerd, maar daardoor kan men niet geheel voorkomen dat er krapte op de arbeidsmarkt voor verplegend en verzorgend personeel ontstaat. Door de lengte van de opleidingstrajecten duurt het immers enige jaren voor het aanbod zich aanpast aan de veranderde vraagsituatie. Vergeleken 
met de verwachte tekorten in het Global Shift scenario zijn de aanbodtekorten en de daarmee samenhangende problemen als recruteringsproblemen, werkdrukverhoging, toenemende arbeidsonrust en loon- en kostenstijgingen in de gezondheidszorg, in European Renaissance echter gering. Schema 8.1 geeft ten slotte een samenvattend overzicht van de belangrijkste ontwikkelingen op de arbeidsmarkt in de zorgsector in de drie scenario's.

Schema 8.1. De belangrijkste ontwikkelingen op de arbeidsmarkt in de zorgsector voor de drie scenario's samengevat

\section{Global Shift}

- Tot 2005 vinden er geen beleidswijzigingen plaats.

- De werkgelegenheid in de zorgsector neemt tot 2005 sterk toe, als gevolg van de demografische druk en de verder gaande groei van het gebruik van zorgvoorzieningen.

- De vervangingsvraag naar schoolverlaters blijft hoog, doordat bijvoorbeeld beperkende maatregelen met betrekking tot arbeidsongeschiktheid niet van de grond komen en ook de instroom van herintreders, mede als gevolg van rigiditeiten in het belastingstelsel nauwelijks toeneemt.

- Tegen het algehele beeld van het scenario in, is er in de zorgsector sprake van enorme recruteringsproblemen, waardoor de werkdruk en de arbeidsonrust in de zorgsectoren zal toenemen.

\section{Balanced Growth}

- Onder meer door de toenemende concurrentie tussen de verschillende aanbieders van zorg is er sprake van een snelle diffusie van technologische ontwikkelingen, hetgeen leidt tot een minder sterk groeiende werkgelegenheid voor de verpleegkundige en verzorgende beroepen in de zorg.

- Ook door efficiëncy-bevorderende maatregelen, zoals de invoering van 'managed care' systemen en substitutieprocessen van relatief dure zorgvormen naar goedkopere vormen van zorg wordt een (werkgelegenheids)besparing in de zorgsector bereikt.

- De invoering van (hogere) eigen bijdragen in de gezinszorg, het kruiswerk en de bejaardenoorden en de omvorming van de traditionele bejaardenoorden tot 'woon-zorg-complexen' heeft eveneens een remmende werking op de groei van de werkgelegenheid.

- De vervangingsvraag naar schoolverlaters neemt sterk af: vrouwen blijven langer werken, mede als gevolg van veranderingen in het belastingstelsel en een verminderde uitstroom vanwege arbeidsongeschiktheid, terwijl het aantal herintreders aanzienlijk toeneemt.

- De studie- en beroepskeuze van leerlingen wordt meer marktconform, mede door aanpassingen in salarissen en secundaire arbeidsvoorwaarden.

- Het gemiddeld opleidingsniveau van de beroepsbevolking neemt toe, doordat inefficiënte leerroutes duidelijk kleiner van omvang worden en er onder meer een grotere doorstroom van MAVO of VBO naar het DGO plaatsvindt. In het leerlingwezen wordt bovendien een aanzienlijke rendementsverbetering gerealiseerd.

- In 2005 zal voor de zorgberoepen de arbeidsmarktsituatie min of meer evenwichtig zijn. Alleen voor ziekenverzorgenden kan de werving van nieuw personeel problemen ondervinden.

\section{European Renaissance}

- Ook in dit scenario worden efficiëncy-verbeteringen bewerkstelligd door de diffusie van nieuwe technologieën en invoering van organisatorische vernieuwingen als 'utilization review' en 'case management'.

- Er vindt een verder gaande extramuralisering van de zorg plaats als gevolg van het aanbieden van zorg op maat. De ziekenhuizen verliezen in belangrijke mate hun hotelfunctie.

- De vervangingsvraag naar schoolverlaters neemt af: vrouwen blijven langer werken, mede als gevolg van veranderingen in het belastingstelsel en nieuwe arbeidsongeschiktheidswetgeving, terwijl het aantal herintreders toeneemt. De afname van de vervangingsvraag is minder groot dan bij Balanced Growth.

- De arbeidsmarktinstroom via het duaal onderwijs neemt vooral bij jongeren toe, bewerkstelligd middels de introductie van opleidingsfondsen. De Arbeidsvoorzieningsorganisatie voert een intensief scholingsbeleid.

- In 2005 zal er een gering tekort aan personeel voor de verpleegkundige en verzorgende beroepen bestaan. 


\section{LITERATUUR}

Borghans, L. (1993), Educational Choice and Labour Market Information, Thesis, ROA, Maastricht.

Centraal Planbureau (1992a), Nederland in Drievoud. Een scenariostudie van de Nederlandse economie 1990-2015, SDU-Uitgeverij, Den Haag.

Centraal Planbureau (1992b), Scanning the Future, A Long-term Scenario Study of the World Economy 1990-2015, SDU Publishers, The Hague.

Centraal Planbureau (1993), Centraal Economisch Plan 1993, SDU-Uitgeverij, Den Haag.

Dirksen, C.D., A.J.H.A. Ament, P.M.N.Y.H. Go, D. Hupkens van der Elst (1994), De diffusie van endoscopische chirurgie, Economisch Statistische Berichten, jrg. 79, nr. 3946, blz. 82-85.

Dorenbos, R. (1994), Werken en leren in de gezondheidszorg: het imago van het werk in de gezondheidszorg onder VBO-, MAVO- en HAVO-leerlingen, afstudeerscriptie ROA/FdEW, Maastricht.

Dunning, A.J. (1991), Kiezen en delen, rapport van de Commissie Keuzen in de zorg, Ministerie van Welzijn, Volksgezondheid en Cultuur, Rijswijk.

Feldstein (1988), Private Cost Containment, New England Journalof Medicine, May 19th 1988, blz. 1310-1314.

Gerritse, A.J., V.J.H.M. van den Heuij, W. van der Windt (1993), Regionale Arbeidsmarktinformatie 1993, gegevens over de intramurale gezondheidszorg op RBA-niveau, Nationaal Ziekenhuisinstituut, Utrecht.

Gerritse A.J., W. van der Windt (1991), Van verloop naar loopbaan, een arbeidsmarktverkenning verpleging en verzorging in de negentiger jaren, Nationaal Ziekenhuisinstituut, Utrecht.

Grip, A. de (1988), Scholing en werk, SMO-boek, Den Haag.

Grip, A. de, J.A.M. Heijke, E.J.T.A. Willems (1992), Scholing en mobiliteit, Maandschrift Economie, jrg. 56, blz. 131-144.

Grip, A. de, P. Meijboom, E. Willems (1993), Vacancies, Employment Growth and the Demand for Newcomers on the Labour Market, ROA-RM-1993/1E, Maastricht.

Grip, A. de, E.J.T.A. Willems, J. Hoevenberg, P.J.E. van de Loo, A.G.M. Matheeuwsen (1994), Opzet en methodiek scenario's arbeidsmarkt zorgsector, ROA-W-1994/3, Maastricht. 
Go, P.M.N.Y.H., W.F.M. van Erp (1993), Werkgroep Endoscopische Chirurgie, Nederlands Tijdschrift voor Heelkunde, jrg. 2, nr. 5, blz. 172-173.

Go, P.M.N.Y.H., F. Schol, D.J. Gouma (1993), Laparoscopic cholecystectomy in the Netherlands, Britisch Journal of Surgery, vol. 80, blz. 1180-1183.

Johnsson, J. (1991), Maneged Care, Hospitals, March 5th, 1991, blz. 40-44.

Klaver, T., A.H. Sprangers (1990), De kwartaal vacature-enquête; methoden en uitkomsten, Supplement bij de Sociaal-Economische Maandstatistiek, nr. 5, blz. 18-24, Centraal Bureau voor de Statistiek, Voorburg/Heerlen.

Knox, E.G. (1979), Epidemiology in health care planning: a guide to the users of a scientific method, Oxford University Press.

Loo, P.J.E. van de, R.J.P. Dekker, A. de Grip (1992), Arbeidsmarktsegmentatie als uitgangspunt voor een beroepenclassificatie, Tijdschrift voor Arbeidsvraagstukken, jrg. 8, nr. 1, blz. 19-31.

Loo, P.J.E. van de, R.K.W. van der Velden (1993), De arbeidsmarkt in de zorg-en welzijnssector, ROA-R-1993/2, Maastricht.

Loo, P.J.E. van de, R.K.W. van der Velden, M.H. Wieling (1993), De arbeidsmarktpositie van afgestudeerden van het hoger beroepsonderwijs, HBO-Monitor 1992, HBO-Raad, Den Haag.

Mantel, A.F. (1993), Kwaliteit en efficiëntie in een concurrerend zorgstelsel, Economisch Statistische Berichten, jrg. 79, nr. 3966, blz. 601-604.

Ministerie van Welzijn, Volksgezondheid en Cultuur (1992), Financieel Overzicht Zorg 1993, Tweede Kamer der Staten-Generaal, Sdu Uitgeverij, Den Haag.

Ministerie van Welzijn, Volksgezondheid en Cultuur (1993), Financieel Overzicht Zorg 19891994, Rijswijk.

Moons, M., A. Kerkstra, C. Picauly (1989), De zorgbehoefte ontleed, een literatuuroverzicht van onderzoek naar de behoefte aan thuiszorg. Nederlands Instituut Voor onderzoek van de Eerstelijnsgezondheidszorg, Utrecht.

Pool, J., E.A.M. Meeuwsen, K.J.A.M. Michels, W. van der Windt (1992), Beheersing personeelsverloop in de intramurale gezondheidszorg, deel 1: achtergronden en landelijke gegevens, OSA-werkdocument W 99, Den Haag.

Researchcentrum voor Onderwijs en Arbeidsmarkt (1993), De arbeidsmarkt naar opleiding en beroep tot 1998, ROA-R-1993/10, Maastricht. 
Thomassen, H., P.J. van der Vange (1991), Arbeidsmarktverkenning sector Bejaardenoorden, Bakkenist Management Consultants, Groningen.

Vissers, A.M.C., G.H.M. Evers, M.H.L. van Tits, H. Vermeulen, R.W. Euwals (1991), De ontwikkelingen op de arbeidsmarkt in de zorgsector tot het jaar 2000, IVA Instituut voor sociaal-wetenschappelijk onderzoek van de Katholieke Universiteit Brabant, Tilburg.

Wieling, M.H., P.J.E. van de Loo, R.K.W. van der Velden (1993), Waar komen onze schoolverlaters terecht?, De uitstroom en bestemming van het schooljaar 1990/1991, Landelijk Dienstverlenend Centrum voor Studie- en Beroepskeuzevoorlichting, Leeuwarden.

Willems, E.J.T.A., A. de Grip (1993), Toekomst in techniek?, Waarde-oriëntatie, beeldvorming en keuze-intenties van jongeren, ROA-R-1993/7, Maastricht.

Zant, W. (1992), Zorg op lange termijn, CPB-onderzoeksmemorandum no. 93, Den Haag.

Zwan, A. van der, C.P. van Dijk, E. Borst-Eilers (1993), Gezondheidszorg in tel, Commissie Strategische Heroriëntatie Gezondheidszorg, Nationaal Ziekenhuisinstituut, Utrecht. 